\title{
The Island of Crete and the Town of Candia
}

[...] leaving behind us the Ionian Sea, we sail through the Aegean. To our right, we see the island of Crete, towards which our ship is travelling, directed to the town of Candia, which we can discern from afar. ${ }^{1}$

Having sailed through the Ionian and along the coasts of the Peloponnese, pilgrims' galleys arrived at the island of Crete and the town of Candia. Although it was one of the most important trading centres in the Mediterranean and a necessary stop on the route leading to the East, the port of Candia, an artificial harbour built by the Venetians, was not always easy to enter. Quite often, mainly because of opposing winds, the ships heading towards the town docked at the safe anchorage of the neighbouring Bay of Fraskia or at the island of Dia (Standia) (Fig. 57). ${ }^{2}$

The Bay of Fraskia, a natural harbour west of Candia, was quite often used by the ships travelling to the city. It is mentioned as a portus, a natural haven, in 1217 , while it is characterised as a safe anchorage in nautical charts and portolans. ${ }^{3}$ The site must have been an important navigational landmark,

1 Louis de Rochechouart (1461): “[...] relicto mari Jovio, navigamus per pelagus Egenum. Ad dextram, vidimus de prope insulam Cretam, ad quam recto calle direximus navem ad civitatem Candidam, vulgariter Candie, que a longe apparet.' Couderc 1893, 233.

2 As can be deduced from the travelogues, many ships docked primarily at Standia; thus the small island appears in the pilgrims' narratives more often than the harbour of Fraskia. Milliaduse d'Este (1440-1441) refers to the small island: 'Et ad ore 24 fossimo sopra la Standia, la quale è una isoletta che è dreto Candia, et è luntana da Candia miglia 12, e via al nostro camino, passiamo Candia [...]. Rossebastiano and Fenoglio 2005, 6o. In 1492 Giovanni di Antonio da Uzzano mentions docking at Standia: ‘[...] Santo Eirini alla Città di Candia, ch' è nell isola di Creti, à 8 o miglia per mezzo giorno verso scilocco, e in quélla via troverai presso una isola, che à nome Estandia, ed è presso di Candia a 10 miglia per tramontana; e qui ha porto dalla faccia di verso mezzo giorno.' Pagnini dal Ventura 1765-1766, 239.

3 Gertwagen 2000a, 195; Georgopoulou 2013, 137-138. 


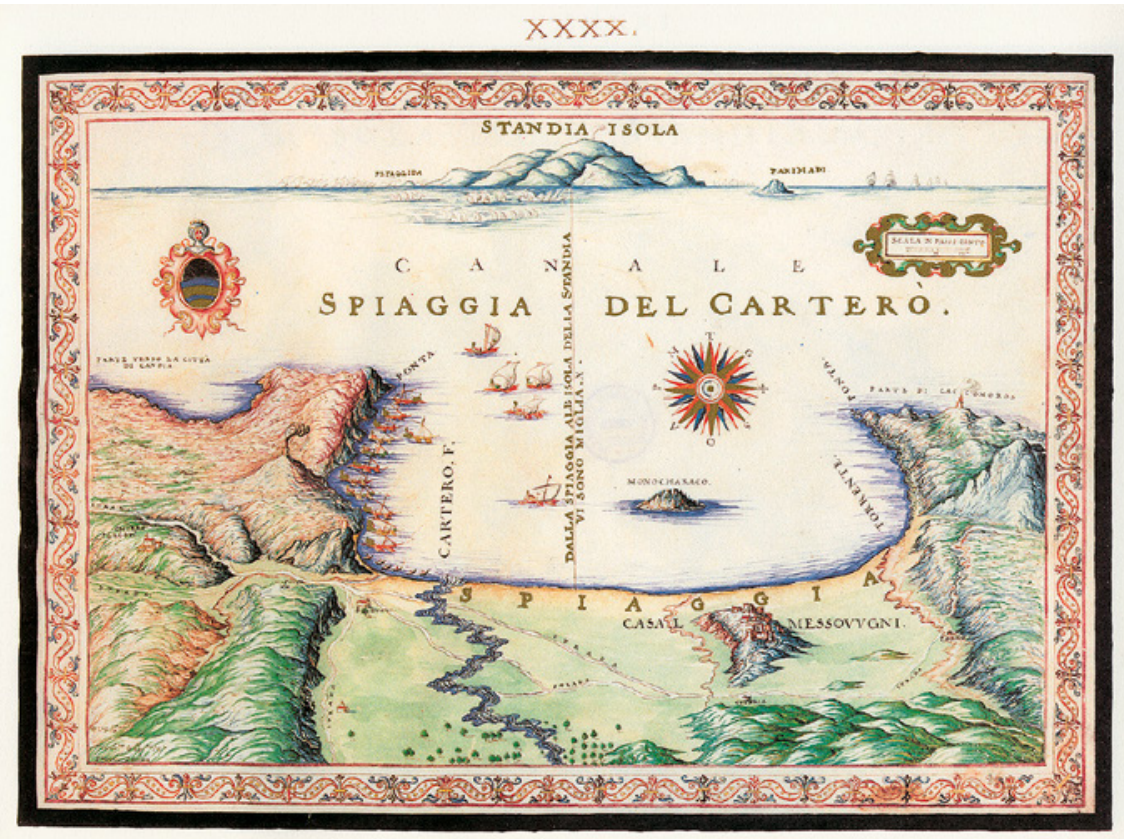

FIGURE 57 The Bay of Carteros and the island of Standia, 1618, manuscript map after F. Basilicata

providing a safe docking point, as well as guarding the approach to Candia. In the 16th century the fort of Palaiokastro was built on the spot (Fig. 58$).{ }^{4}$ In the same bay, at an inlet in the peninsula, stood a Greek monastery and its church dedicated to the Virgin, Santa Maria della Fraskia. ${ }^{5}$ The site's importance for the ships travelling in the area and their crew is also attested by its integration into the holy topography of sailing, the 'holy portolano' described in the Santa Parola litany: Die n'aie Santa Maria della Fraschea di Candia. ${ }^{6}$

A number of pilgrims mention stopping at Fraskia before conditions allowed them to enter the port of Candia. ${ }^{7}$ References to this church appear

4 Georgopoulou 2013, 138.

5 Bacci 2004b, 233, n. 20; Georgopoulou 2013, 137-138. Count Alexander von Pfalz-Zweibrücken (1495-1496) writes: 'Achtzehn Meilen Wegs von Candia ist ein Kloster, genannt Unsere Liebe Fru von Fraskia, vongriechischen Mönchen, da unsereliebe Frau fast gnädig ist.' Karbach $1997,58$.

6 About the seafarers' prayer, the Santa Parola, see p. 12, n. 11 herein.

7 André Thevet (1549-1552): 'Le dixhuitieme de Iuillet nous arriuames en Fresquie, qui est un port loin dix miles ou enuiron, de Candie. La nous prinmes terre pour prendre air, \& recreacion, laquelle nous estoit fort agreable \& necessaire, pourautat que l'esprit apres tel 


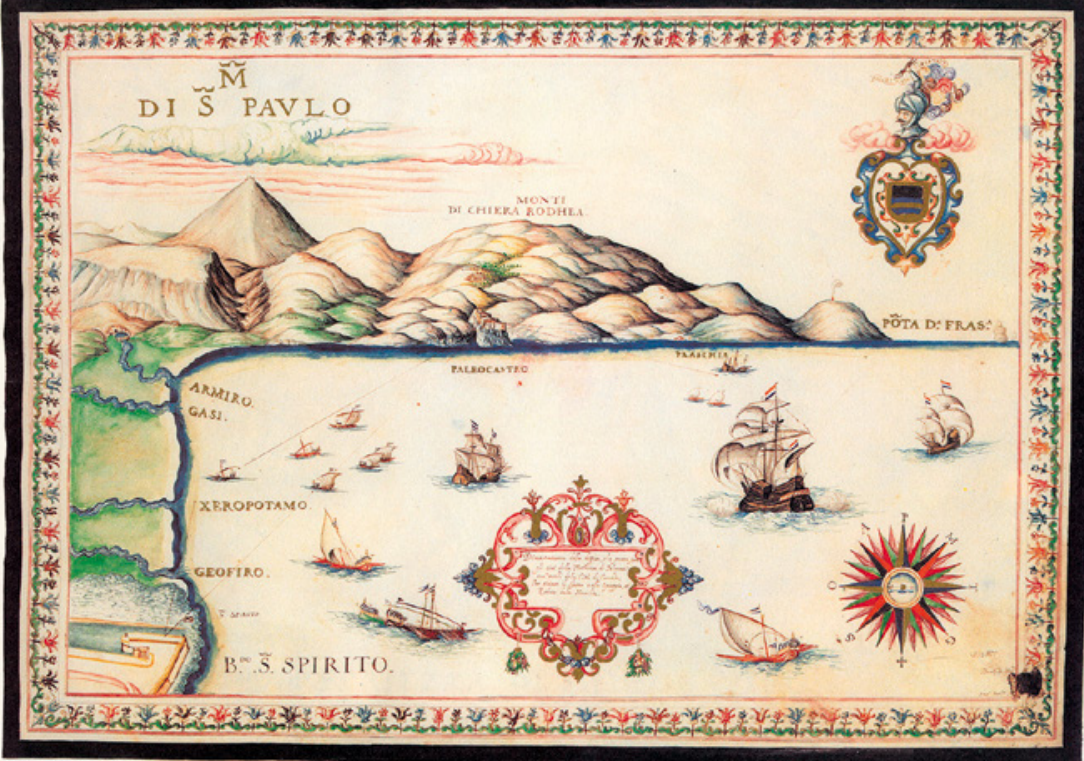

FIGURE 58 The Bay of Fraskia and the fort of Palaiokastro, 1618, manuscript map after F. Basilicata

in very few travelogues, as in the one of the German Count Alexander von Pfalz-Zweibrücken (1495-1496) and the narrative of the Italian Francesco Grassetto da Lonigo (1511). ${ }^{8}$

Along with Santa Maria della Fraskia, another church also marking a docking point on the western approach to Candia's harbour is evoked in the seafarers' prayer: Santa Vereconda di Candia. ${ }^{9}$ The church has been identified as Santa Veneranda (Agia Paraskevi), a foundation on the Bay of Dermata that was likewise used as an anchorage for small ships, but it does

refreschissement est beaucoup plus esueille, mesme les vertuy naturelles estre refocilees par intermision moderee, sont plusfortes au labeur, quau parauant.' Thevet 1556, 34 .

8 Count Alexander von Pfalz-Zweibrücken (1495-1496): 'Achtzehn Meilen Wegs von Candia ist ein Kloster, genannt Unsere Liebe Frau von Fraskia, von griechischen Mönchen, da unsere liebe Frau fast gnädig ist.' Karbach 1997, 58. Francesco Grassetto da Lonigo (1511): 'A hore x de notte da Retimo dipartimo, et a una hora ritrovamosi per mezo Milopotimo, et a duo hore ala ponta de Tali, et a III a sancta Pelagia over Panagia apresso la Fraschia, dala quale vedevamo la famosa Creta, in porto de la qual al muolo sorti et ligati, scala in terra damo a hore xx.' Ceruti 1886, 19.

9 Bacci 2004b, 243 . 


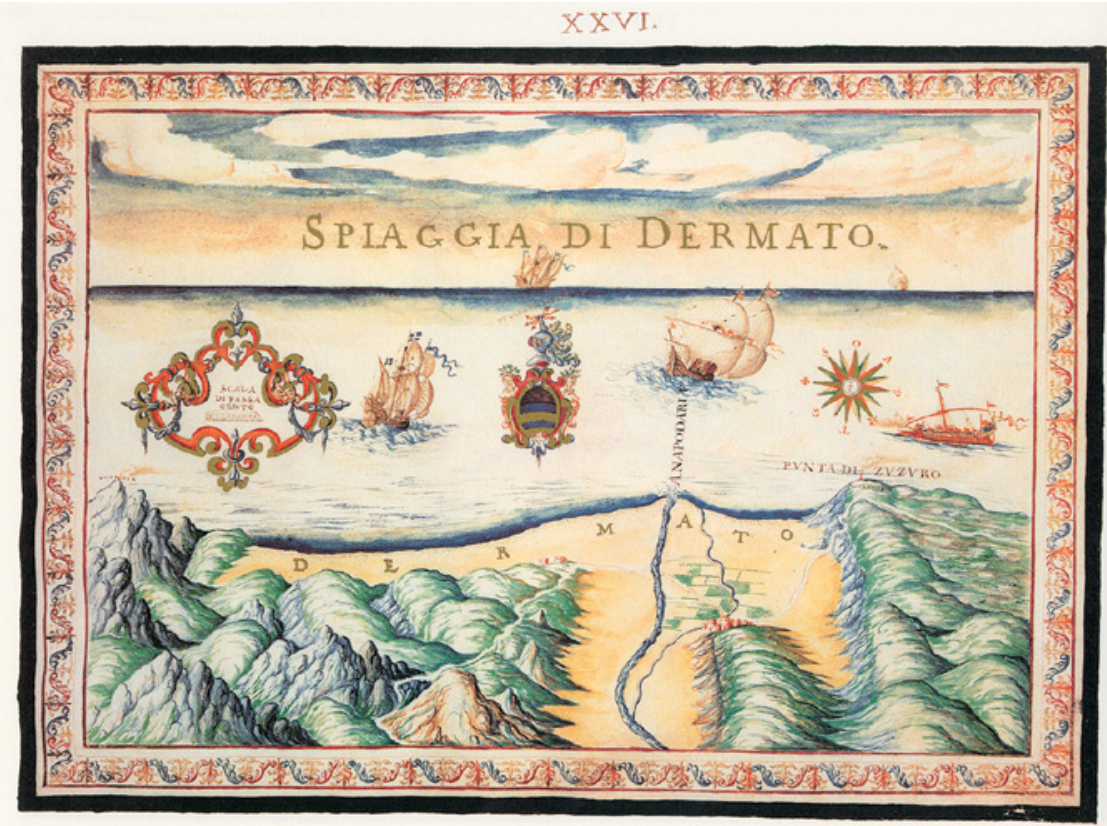

FIGURE 59 The Bay of Dermata, 1618, manuscript map after F. Basilicata

not appear in any of the travelogues (Fig. 59). ${ }^{10}$ Maria Georgopoulou has suggested that these two religious foundations could have had lights burning to indicate their location to approaching ships, functioning as ad hoc lighthouses. ${ }^{11}$ The idea of a church in a small harbour functioning as a 'religious lighthouse' for ships sailing by brings to mind the church of the Virgin in Kassiopi and its perpetual oil lamp, the light of which was visible from outside as one approached. ${ }^{12}$

However, unlike the case of the church in Kassiopi, the churches of the Virgin in Fraskia and St Veneranda, the only two sites on the island of Crete evoked in the Santa Parola, rarely appear in the pilgrims' narratives. In fact, out of the five sites included in the Santa Parola within the geographical limits of this study (the aforementioned three, the Virgin of Strophades and St Leo of Modon), the two Cretan churches are the only ones that are practically omitted

\footnotetext{
10 Bacci 2004b, 233, n. 19; Georgopoulou 2013, 138-139.

11 Georgopoulou 2013, 139, n. 21.

12 'Von aussen sieht man ein kleines Lemplein, das Brenet ausswendig vorm Bild tag und nacht.' Geisheim 1858, 212.
} 
in the travelogues. It is clear that all of the above were of particular significance to the sailors. However, the Cretan churches are both located extra urbem, at sites where few of the pilgrims could actually visit. In addition, unlike the other three sites, they were not invested with legends, nor had miraculous effigies to show. Thus, the pilgrims, anticipating their disembarkation at Candia, a celebrated city with a patron saint who was a disciple of the Apostle Paul, almost ignore them. The churches of the Virgin of Fraskia and St Veneranda obviously belong to the peregrinagia maritima, visited almost exclusively by mariners..$^{13}$ The reason for their initial insertion into the holy topography of sailors is quite obvious: they functioned as orientation points for navigation, leading the ships to a safe harbour protected from weather conditions. It is exactly this reason, inextricably connected to sailing, that could possibly explain their omission from the travelogues: while these sites had particular relevance to the sailors, the pilgrims sought and saw different things. ${ }^{14}$

Candia was inserted into the trading network of the Eastern Mediterranean after the arrival of the Venetians in 1211. Before that time, commercial ships used other ports of the Aegean islands, while docking at Crete was considered to be a deviation. However, during the time frame of this study, Candia was one of the most important Venetian commercial ports of the Mediterranean and a necessary stop for galleys travelling from the West to the East and vice versa, hence most of the pilgrims' galleys usually docked and remained for several days in the town..$^{15}$ The capital city of the island and its port were strongly fortified, and the first impression of it as seen from aboard seems to be more or less common for the pilgrims (Fig. 6o). Jacques Le Saige, who visited Crete in 1518, expresses most eloquently what the majority of the voyagers thought about the town: 'On the ninth day of July, around dinner time, we arrived in

13 Such peregrinaria maritima looked mostly at rather anonymous chapels, small churches and hermitages that were invested with a special meaning only for those who saw them from the sea, because of their locations in eminent points along the coastline. Bacci $2017 \mathrm{a}, 133$.

14 A theory expressed by Maria Georgopoulou, who continues: 'This observation confirms the existence of two distinct types of travellers: the sailors, crew and traders who took this voyage often and the pilgrims for whom, like for modern tourists, the voyage was a novelty and a religious experience that was often recorded.' Georgopoulou 2013, 134.

15 About the port of Candia, see indicatively Gertwagen 1988; Gertwagen 200oa; Georgopoulou 2013, esp. 135-139. 


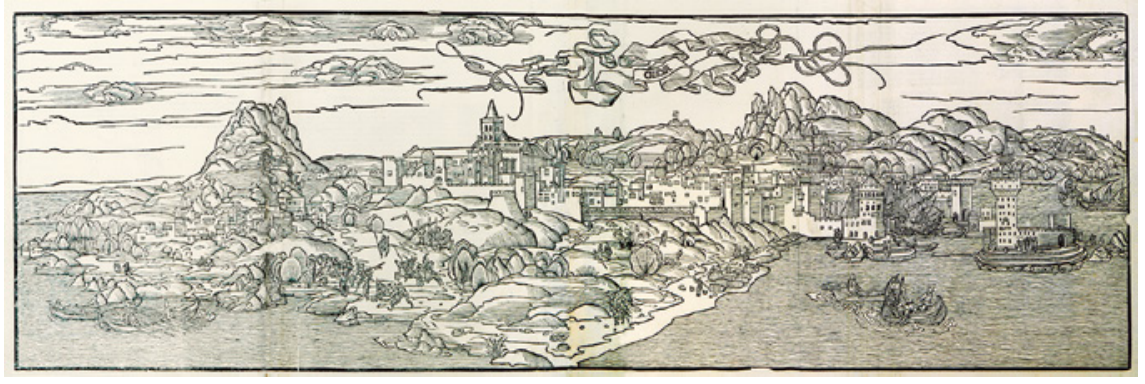

FIGURE 60 View of Candia, 1486, woodcut

Candia. The town seemed beautiful from afar; and there were people saying that it could be one of the beautiful and strong cities of France.'16

Most of the pilgrims visiting Candia mention its beauty and its strong fortification walls. Already at the beginning of the 14th century, the Irish Franciscan monk Symon Semeonis describes the strongly fortified beautiful town and its surrounding strong walls, adorned with towers. ${ }^{17}$ Similar mentions to the town were made by the majority of the Western travellers visiting it. ${ }^{18}$ The depictions of Candia in the isolarii of the period, as well as in some pilgrims' narratives, perhaps provide a quite accurate idea of the port and the town, with its impressive fortifications, the Franciscan and Dominican monasteries and the cathedral being visible from the ship (Fig. 61).

As in all the towns where the pilgrims stopped within the geographical frame of this survey, the awareness that they were visiting a Greek city of the former Byzantine Empire is obvious in their writings. The rich history of Candia from prehistoric times (known for its one hundred cities, King Minos, the labyrinth and the cave of Zeus) to its Christian past and relation to the Apostle Paul, as

16 'Ce neuvième jour de juillet ainssy que au disner arrivasmes audit Candie. Che nous sambloit merveille par dehors; et en y avoit qui volloient gaigier que c'estoit une des belles villes de France et forte.' Duthill 1851,8 o.

17 ' [...] civitatem muro fortissimo circumcinctam, turribus atque aliis bellicis apparatibus decoratam [...] Que quamvis sit in aspectu navigantibus pulcra, karerias tamen habet vilas [...].' Esposito 196o, 42.

18 Giacomo da Verona (1335): '[...] civitas pulchra est et amena et omnibus deliciis plena'. Röhricht 1895, 175. Louis de Rochechouart (1461): ‘[... Est pulcherima, bene murata; altissime domus et omnes lepide sunt. Ibi ecclesie multe Grecorum et Latinorum.' Couderc 1893, 234. French anonymous (1480): 'La cité est belle' et forte et non pas tant de beaucoup que Raguze. On la fortifie continuellement et est bien artillée.' Schefer 1882, 49. Felix Fabri (1480, 1483-1484): 'Civitas haec est magna et populosa et negotiatoribus plena de omni gente congregatis. Dependet autem ad clivum contra mare estque optime munita moenibus, turribus et muris et fossatis.' Hassler 1843-1849, vol. 3, 281. 


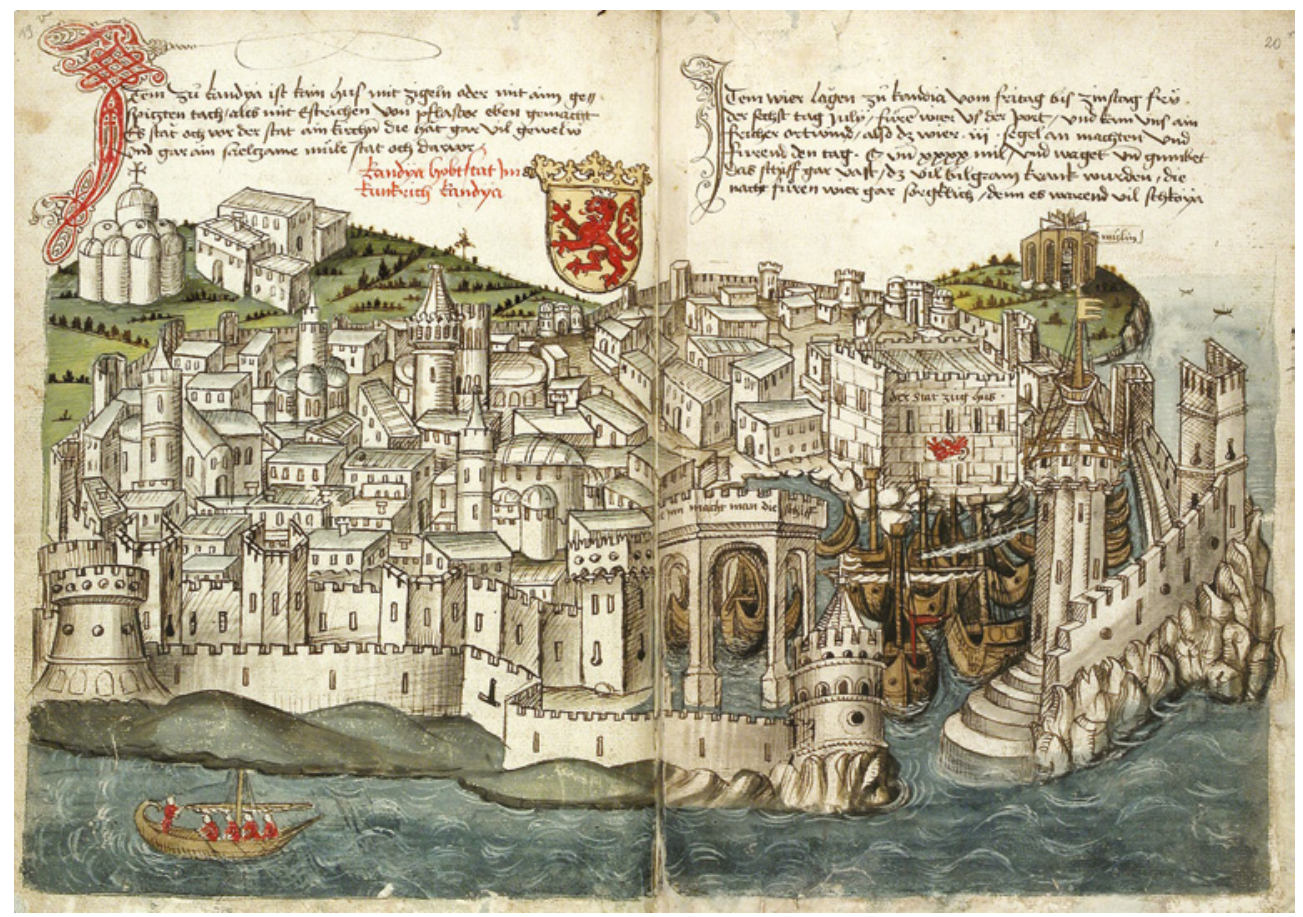

FIGURE 61 View of Candia, c. 1487, manuscript illumination

well as the more recent events of the Venetians' arrival and even the resistance of the locals, are all recorded in detail in many of the travelogues.

Upon entering the port of Candia 'the most beautiful and well-fortified town, ${ }^{\prime}$ voyagers came across a crowd of many ethnicities, commercial galleys, shops and warehouses and disembarked while the crew of their ships was already unloading merchandise. As some of the pilgrims describe, the arrival of their galleys in the port was occasionally greeted by the residents of Candia. ${ }^{20}$

Reaching the town, the pilgrims' first impression often shifted, as in the case of Jacques Le Saige (1518), who, after saying that the town looked beautiful from afar, adds that when entering it he realised that his first perception

19 Anonymous, Le voyage de la saincte cyté de Hiérusalem (1480): ‘[...] qui est le plus beau et mieulx fermé que je veis oneques'. Schefer 1882 (1970), 49.

20 Pietro Casola (1494): 'Non obstante fosse per tempo, erano tante persone de ogni fatione, sopra la ripa del porto, chi per vedere la galea, la qual era ornata de diverse bandere, chi per dare adiuto, che era una maraviglia de vedere.' Paoletti 2001, 148. An analogous reception of the galley he was travelling on is described by Jean Thenaud (1512), Schefer 1884, 164 . 
was erroneous. ${ }^{21}$ Continuing, he describes a town devastated by an earthquake that left behind 7000 dead. ${ }^{22}$ In fact, quite often in the narratives the town is described as ruined by earthquakes or infested by plague. ${ }^{23}$

The medieval town of Candia was a multicultural city, with a mixed population of Greeks and Latins, as well as a large community of Jews, who resided in the walled 'old town' and the borgo. ${ }^{24}$ As a major commercial harbour and a necessary stop for galleys travelling to the East or the West, the town was large and wealthy, inhabited and frequented by people of many different ethnicities. ${ }^{25}$

According to the travelogues, Candia was beautiful and rich, very big in size, with wide streets and beautiful houses, although built in the 'Eastern way', with flat roofs. ${ }^{26}$ Being a major commercial port, Candia offered facilities to travellers, traders and the crews of the various ships frequenting it. Provision was made for the accommodation of the pilgrims, who could reside at the mendicant monasteries of the town and the hospice of St Anthony. ${ }^{27}$

As the town was expanding outside the limits of the 'old' fortified city, a large number of houses, warehouses, commercial stores and, of course, churches and monasteries were built in the borgo. It was there that most of the pilgrims resided, where they could find taverns and where large markets were held.

21 ' [...] mais quant fusmes dedens veismes bien le contraire'. Duthill 1851, 8 o.

22 Duthill 1851, 80.

23 Among others, the two French pilgrims Louis de Rochechouart (1461) and the anonymous writer of Le voyage de la saincte cyté de Hiérusalem (1480) mention the plague. Couderc 1893, 234; Schefer 1882, 49. Jean Thenaud (1512), Jacques Le Saige (1518), Nicolas Loupvent (1531) and Jodocus von Meggen (1580) describe the town as recovering from an earthquake. Schefer 1884, 165; Duthill 1851, 80; Bonnin 1976, 56; von Meggen 1580, 54 .

24 Symon Semeonis (1322-1324): 'Inhabitatur enim Latinis, Grecis et Judeis perfidis, quibus preest dux civitatis qui Duci inclito Venetiarum subjacent.' Esposito 196o, 42.

25 Felix Fabri (1480, 1483-1484): '[...] magna et populosa et negotiatoribus plena de omni gente congregatis'. Hassler 1843-1849, vol. 3, 281 .

26 Anonymous, Le voyage de la saincte cyté de Hiérusalem (1480): 'Toutes les maisons, tant de la ville, faulxbourgs que villaiges d'entour, sont haultes et de fortes pierres et sont toutes plates dessus comme une belle salle.' Schefer 1882 (1970), 50.

27 Wilhelm Tzewers (1477-1478): 'In Candia, ut patebi infra, hospitale hospicium peregrinorum est in bono alto situ et ameneo.' Hartmann 2004, 80. The Dominican friar Felix Fabri, despite the fact that during his first visit to Candia (1480) he did not find a lodging to his liking and ended up residing in a brothel run by Germans, refers to the hospice of St Anthony: 'In eodem suburbio est hospitale magnum S. Antonii, quod habet dormitorium cum multis cellis pro collocatione peregrinorum de Jerus alem venientium, in quo etiam aliquando hospitatus fui.' Hassler 1843-1849, vol. 3, 282. About the accommodation of pilgrims in Candia, see Georgopoulou 2013, 150-151. 
Almost all of the Western travellers who visited Candia refer to its abundance of products, such as fruits, vegetables, cheese and its famous Malvasian wine. ${ }^{28}$ Besides the wine and agricultural products, there seems to have been a market that specifically targeted the pilgrims; there one could find religious mementoes, such as images of the Virgin of various sizes, paternosters and small wooden crosses: 'In the town there are many carpenters who make cypress chests, small boxes to put corporals, rosaries and small crosses of cypress wood that the pilgrims buy.'29

As in the cases of the other Venetian-ruled towns within the former GreekByzantine territory, Candia remained in most of its aspects a Greek/Levantine city. As clearly stated in the travelogues, despite the fact that the Latins ruled the island, its inhabitants continued living and praising God in their own 'Greek way'.

In the late 15th century the Flemish diplomat Anselmo Adorno (1470-1471) reports that the island's population is mainly Greek. ${ }^{30}$ At the beginning of the 17th century the French pilgrim Henry Castela attests to what was the norm, according to the Venetian policy towards its subjects in all the areas of the former Greek/Byzantine territories: 'The inhabitants of this island live the "Greek way"; in any case, the Venetians, who are its rulers, allow them to live freely.' 31

The pilgrims, who were surprised and fascinated by their first encounter with an Orthodox population in the town of Corfu, now appear accustomed to it to a certain extent. By the time the galleys arrived in Candia, the different expressions of several aspects of religious life as conveyed in common ceremonies and litanies or even in religious buildings themselves - as in the

28 The French traveller Louis de Rochechouart (1461) writes: ‘[...] in multis commendatur hec civitas et primum in vina, et vix cum aqua pre nimia fortitudine temperantur. Veniunt mercatores a multis partibus mundi pro hiis vinis amendis.' Couderc 1893, 234.

29 Jean de Tournai (1488-1489): 'Dans la ville sont de nombreux menuisiers qui font des coffres de cyprès, des petites boîtes à mettre des corporaux, des chapelets et des petites croix de cyprès que les pèlerins achètent.' Péricard-Méa and Blanchet-Broekaert 2012, 167. See also Jacques Le Saige (1518): '[...] et il se fait aussy a ladite ville largement de belles ymaiges de nostre dame encloses de tableaux de Chipres, et des tables et des coffres grants et petits, et des fuseaux, des pater nostre et mesmes de bateaux, et nostre nave y avoit estés faicte, qui estoit tout de chipres.' Duthill 1851,82 . A market targeting pilgrims is also attested by other pilgrims, for example Pietro Casola and Felix Fabri. About the icons produced and sold on Crete, see Vassilaki 2010; Newall 2016, esp. 129-132.

30 Anselmo Adorno (1470-1471): '[...] bene populata est, quorum major pars Greci sunt [...]'. Heers and Groer 1978, 158.

31 'Les habitans de ceste isle vivent presque tous à la façon des Grecs; toutesfois les Venitiens, qui en sont Seigneurs, les laissent vivre en leur liberté.' Castela 1603, 478. 
cases of double-rite churches - was not something entirely new to the eyes of Western travellers. However, this different reality continued to attract their attention; thus, descriptions of majestic ceremonies with the participation of both clergies, impromptu processions and ritual habits of the Orthodox still appear regularly in the travelogues. At the beginning of the 16th century the pilgrim Georg von Gaming (1507-1508) was amazed by the Good Friday procession. This litany took place every year with the participation of Latins and Orthodox. ${ }^{32}$ In 1494 the Italian pilgrim Pietro Casola witnessed and vividly described an impromptu procession following a series of earthquakes. ${ }^{33}$

As in all the ports of call in the former Greek/Byzantine territory, the appearance of the Orthodox priests with their 'peculiar' habits, as well as local Byzantine-rooted rituals, attracted the attention of pilgrims. Many such descriptions survive in the travelogues in reference to the town of Candia, where several pilgrims attended and described Orthodox liturgies. ${ }^{34}$ The anonymous author of Le voyage de la saincte cyté de Hiérusalem (1480), Pierre Barbatre (1480) and Nicolas Loupvent (1531) appear to have been fascinated by the local rituals of death, while the latter two make interesting observations on the differences between Latin and Orthodox churches, noting that Greek churches may not be as majestic as the Latin ones, but are adorned with beautiful fresco decorations. ${ }^{35}$

32 About the Good Friday celebration and procession, see n. 191 below. Georg von Gaming describes it as follows: 'Ante hunc verò diem, id est, in die Parasceves, vidimus quoddam tale spectaculum. Erant in comitatu trecenti ferè Latini pariter \& Graeci, qui ante festa Paschae facem totùmque corpus velabant, solo dorso excepto. Hi per omnes plateas obeuntes, flagris acutissimis dorsa caedebant, adeo, ut per flagella, vestis tota caro ac platearum solum cruore manaret. Fertur verò quosdam inter eos fuisse, qui id genus flagellationis in recompensam passionis Christi spontè subirent. Majorem tamen partem fuisse dicunt eorum, qui idipsum pretio ab aliis conducti facerent \& paterentur. Moris enim esse Senioribus terrae illius, ut, cùm ipsi aut prae senio, aut prae valetudine corpus suum acerbiùs tractare non pravalent, alios, qui id loco eorum agant, subordinent. Itaque videas plures ephebos amore pecuniae corpus suum quasi trunctum aut statuam sine sensu saeviendo ferire, ictus sonare, saniem profluere ac omnia cruore soedari. Quid enim non mortalia pectora cogit auri sacra fames? Ad hoc spectaculum civitas tota effusa, adulti \& pueri, mares ac foeminae per intervalla acclamitant; Latini quidem misericordia,

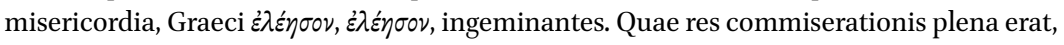
ut namo, nisi ferrea habuisset pectora, se a lachrymis continere potuisset.' Pez 1721, p. 164.

33 See n. 205 below.

34 See the description of Jacques Le Saige (1518): 'C'est une chose merveilleuse des cerimonies qui font et dure plus trois fois que les messes de nostre pais; aussy ils ne dissent que les dimenches et les bons jours.' Duthill 1851,81 .

35 French anonymous (1480) writes: 'Et les Grecz ont une coustume que quant l'homme ou la femme est morte, il y a gens propres qui, ung an durant, vont ès maysons desdictz 
The relations of the Latin rulers with their Greek subjects never cease to interest the pilgrims travelling through Greece, even more so in the case of Crete, since the apostle himself had written about the islanders: 'One of them, a prophet of their own, said, "Cretans are always liars, evil beasts, slothful bellies." This testimony is true. ${ }^{36}$ Those words of the apostle were of course well known to the pilgrims, who often repeated them when writing about Crete. In the travelogues this expression came to be added to the fact that 'the vast majority of them [Cretans] are heretics', negatively predisposing the Western visitors to Candia, while the German Dominican friar Felix Fabri (1480, 14831484) wrote about the animosity of locals towards the Latins. ${ }^{37}$ However, when arriving on Crete many pilgrims formed an opinion of their own concerning the local Greek population, whom the majority of them came to like. ${ }^{38}$

As a former Byzantine capital, Candia had an Orthodox past that survived, among other ways, in its many churches. So, in the town the pilgrims could visit '[...] a great many beautiful big churches, both Orthodox and Latin'. ${ }^{39}$ The map of the city of Candia, containing the names of the Latin and Orthodox churches of the town, made by the Swiss General Hans Rudolf Werdmüller right before its occupation by the Ottomans (1668-1669) is revealing (Fig. 62). It attests not only to the fact that the Orthodox institutions were more than three quarters of the total of 135 churches listed, but also demonstrates the large number of churches existing in the town. ${ }^{40}$ Besides the town's cathedral, which was seized by the Latins along with the relics held in it, the new rulers

Greez, tous les matins, faire de grans cris et lamentations en signe de deuil. Nous cuydions que ce fussent gens enragez qui cryassent ainsi.' Schefer 1882, 51-52. About the Orthodox churches, Pierre Barbatre attests: 'Nota que en toutes les eglises des Grecz ne y a quelque ymage de crucefix, Nostre Dame, sainct ou saincte, sinon en paincture [...].' Pinzuti and Tucoo-Chala 1972-1973, 122. Nicolas Loupvent (1531) adds: 'Au reste se sont toutes esglises grecz, que sont en nombre plus de centz, mais ce nest pas grant chose a dire, voir au regart des esglises latines; mais a mon semblant, comme celuy qui a esté présent, ne sont point moin décorée tant en dévotion comme en cérémonie.' Bonnin 1976, 56.

36 Titus 1:12-13.

37 Pietro Paolo de Rucellai (1500-1504): 'La maggior parte sono eretici.' Da Civezza 1879, $5 \circ 7$. Felix Fabri (1480, 1483-1484), see n. 327 below.

38 Jean Thenaud (1512): 'Candie est une ville très policée; les habitants sont pleins de courtoisie; ils sont bien vêtus et portent des manches a commodo.' Schefer 1884, 167 .

39 Nicolas Loupvent (1531): '[...] sont aincor en grant nombre de belles grandes esglises tant grecz que latine, comme la grande esglise cathédrale monseigneur sainct Tite, deux belles esglises des Cordeliers, grandes et spacieuses, dont les ungz sont réformés et les aultre non, les prédicateurs Carmes, Augustins sont tous latins'. Bonnin 1976, 56 .

40 For the map, as well as the list with the names of the churches, see Gerola 1918; Georgopoulou 1994. 


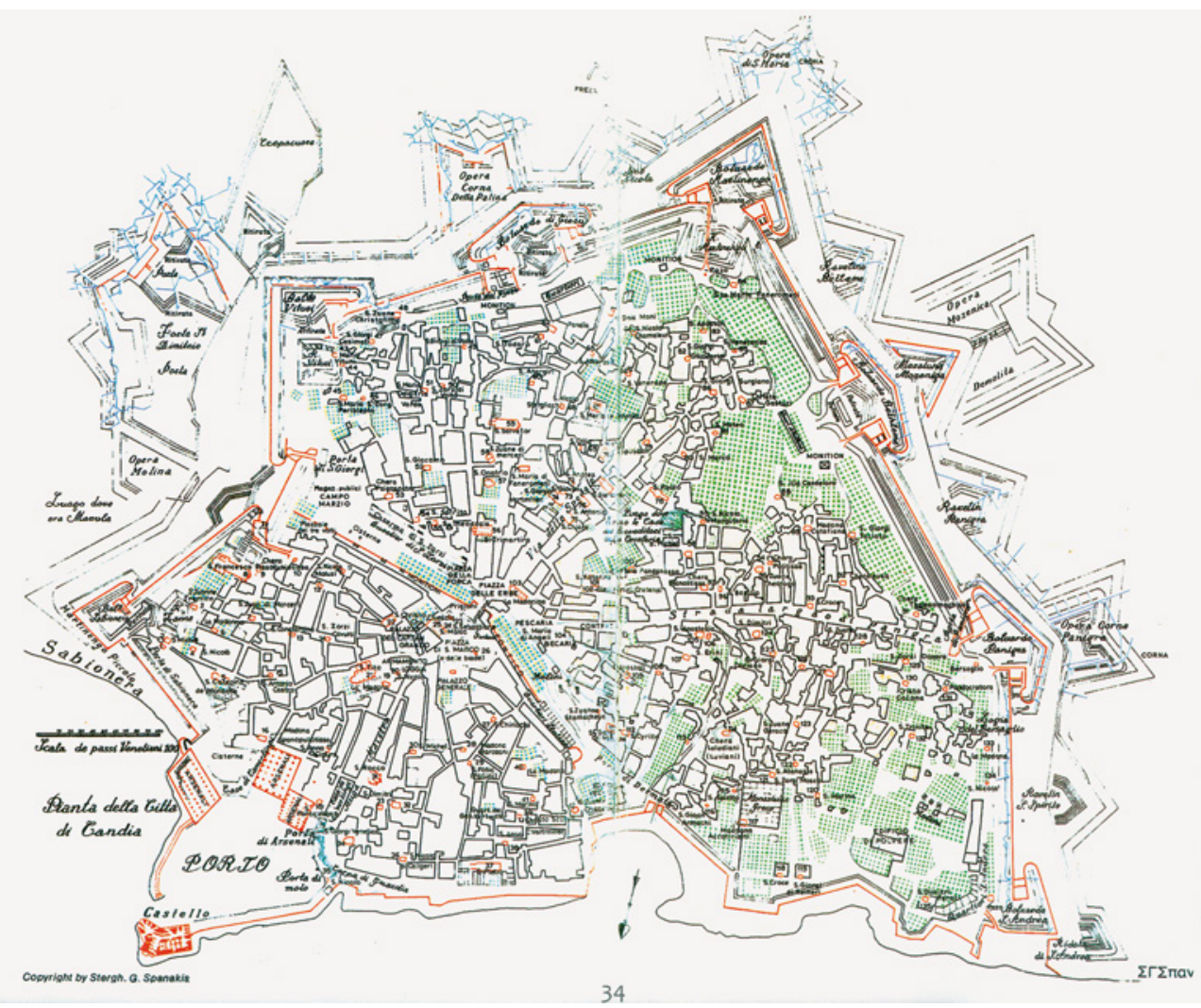

FIGURE 62 Map of Candia, after H.R. Werdmüller

built a number of churches in the town and the borgo. The ones standing out both in the urban space and in the travelogues were the mendicant monasteries and especially the majestic monastery of the Franciscans, imposing both in size and decoration. However, the Orthodox churches outnumbered the Latin ones to an extent that did not go unnoticed by the pilgrims: 'All the churches are Greek besides the ones of the mendicant orders and two or three more, ${ }^{41}$ said one, while 'In the town and its borgo there are at least one hundred churches, and it seems to me that only six or seven of them are not Greek. ${ }^{42}$

41 Anonymous, Le voyage de la saincte cyté de Hiérusalem (1480): 'Toutes les eglises sont grecques excepte les religions et deux ou trois aultres.' Schefer 1882 (1970), 50.

42 Pierre Barbatre (1480): 'En la cité et dehors sont bien cent eglises et me semble qu'il n'en y a que VI ou VII que toutes ne soient grecques.' Pinzuti and Tucoo-Chala 1972-1973, 123. 
As a result, and unlike the other ports of call within the area of this study, several Orthodox churches of Candia appear in the travelogues. The Orthodox cathedral, dedicated to St Mary of the Angels, as well as the monastery of St Catherine, a dependency of the famous Sinai monastery, two of the most prominent Orthodox establishments of Candia, appear sparsely in the pilgrims' narratives. On the other hand, two seemingly less important churches, the church of the Holy Cross and Santa Maria dei Miracoli, seem to stand out among the rest of the Greek religious institutions.

\subsection{The Hermitage of St Paul and the Church of the Holy Cross}

The small chapel dedicated to the Holy Cross, located on a mountain summit outside the town, amasses a significant number of references in the pilgrims' narratives. In fact, it is the third most mentioned site of Candia, appearing in the travelogues more times than the impressive Dominican monastery of the town. It was the place where, according to the legend, St Paul resided for a period of time, chased by the Cretans, and where he wrote his epistles to the island's patron saint: 'Also there preched Seint Paule the faith of Almyghti Crist and therfor thei saie there the Grekis drove him to a hille. And there hee wrote the Epistolis ad Titum. And there as hee wrote is a chapelle of Seint Crucis.' ${ }^{43}$

The island of Crete has been closely related to the apostle, since, according to the ecclesiastical tradition, it was visited by him twice: once during his transportation to Rome as a prisoner and once around 62 or $63 \mathrm{AD}$ when, along with his disciple St Titus, he travelled there to preach the Gospel. ${ }^{44}$ The southern coasts of the island, a grotto next to Kaloi Limenes and the seashore near the village of Agia Roumeli, as well as the small islet of Gavdos, are mentioned in the Acts of the Apostles in relation to Paul's first visit to Crete. ${ }^{45}$ In particular, according to a popular legend, the saint disembarked at the seashore around the area of Kaloi Limenes, where he baptised the first Christians on Crete with the fresh water that ran through the beach gravel. ${ }^{46}$ Around the 1oth or 11th century the site of the apostle's disembarkation was marked by a small cruciform chapel. ${ }^{47}$ Another chapel, this time on top of a mountain, marked

43 English anonymous (1480), Brefeld 1985, 153. The same information is conveyed by Jan Hasištejnsky in 1493 and Denis Possot in 1532. Strejček 1902, 32; Schefer 189o, 131. Some scholars support that Paul visited Crete as early as $54 \mathrm{AD}$, while others place his visit to the island after the spring of 64 AD. Detorakis 1970, 21, n. 2. Acts of the Apostles, 27:7-8, 12 .

46 Nixon 2006, 62, n. 70.

47 The church of St Paul on the coast east of Agia Roumeli is a small cruciform building $(6.50 \times 8.30 \mathrm{~m})$, accessible only on foot or by sea. It has been dated to the 1oth or 11th century and is believed to have been founded by Ioannis Xenos. At some point, probably 
the site of the saint's stay during his second visit to the island: the church of the Holy Cross. According to the tradition, the apostle resided for a period of time on a mountain summit, where he wrote several of his epistles. As transmitted by another popular legend, it was there that he was attacked by a snake, was liberated from it and subsequently freed the island from poisonous serpents. The Augustinian friar Giacomo da Verona, who visited Crete in 1335, refers to this legend when writing about the apostle's stay on the island. ${ }^{48}$

The apostle's passage via Crete and the legends concerning it seem to have been common knowledge for the pilgrims and hence were mentioned by many of them in their travelogues. The southern coast of Crete was difficult to explore and navigate: by the 13th and 14th centuries the route had become obsolete, and thus the aforementioned sites do not appear often; yet the church of the Holy Cross, on the other hand, has a constant presence in the pilgrims' narrations.

St Paul's short-term hermitage falls into a category of holy sites not yet encountered in the studied area, the 'extension of the Holy Land': sites and places connected to the apostles, visited by them during their frequent voyages around the Mediterranean. ${ }^{49}$ As already mentioned in relation to the icon of the Virgin in Kassiopi, as well as the rest of the Lucan icons, when apostolic connotations were attached to an icon, relic or site it was automatically elevated to a more worship-worthy item or place, an evangelic memorial that pilgrims appeared eager to approach. ${ }^{50}$ Subsequently, and following the notion that the holiness of the land resided in its memorial meaning, the site that hosted the apostle himself became holy by extension. ${ }^{51}$

The popularity and resonance of this notion is directly reflected in the number of references in the pilgrims' travelogues to the church of the Holy Cross and the mountain where the apostle resided. Actually, a number of pilgrims refer to the site where Paul 'was chased by the Greeks' without mentioning the

around 1300 , it was decorated with frescoes, while by the 17 th century the site appears to have been abandoned and used by pirates. See Nixon 2006, 62, 64-65; Georgopoulou 2013, 143-144.

48 'In illa insula Crete, est unus mons altissimus, qui videtur de mari multum longe, ubi Sanctus Paulus liberavit seipsum a serpente seu vipera vulneratum, ut legitur Actus, XXVIII, cap. 6, et ibidem dicitur, ipsum dedisse illi, qui ipsum hospicio suscepit, gratiam contra serpentes et suis heredibus ex eis descendentibus, et vocatur ille mons Sancti Pauli [...]' Röhricht 1895, 175. The same legend is transmitted by the Italian monk Francesco Suriano (1481-1484): 'In questa insula non se trova animale venenoso (exepto le fonine) che noze ad homo, per la benedictione che li diede San Paulo.' Golubovich 1900, 249.

49 Bacci 2017a, 132.

$50 \quad$ Bacci 2012, 148.

$5^{1} \quad$ Bacci $2017 \mathrm{a}, 132$. 
church marking the spot. ${ }^{52}$ While the site of the apostle's hermitage appears in the travelogues already from the beginning of the 14th century, the church of the Holy Cross was first mentioned at the beginning of the 15th century by the Florentine Cristoforo Buondelmonti.

According to the above, it becomes clear that the site was considered to be holy because of its connection to the apostle, and it was not the church, which could have been erected in a later period, that sanctified the area. This would explain the fact that, even after the construction of the church of the Holy Cross, several pilgrims omit to mention it when referring to the site of the apostle's retreat. The importance of such a site in the framework of the holy itinerary can also be attested by the fact that a number of pilgrims actually visited it, even though they had to walk for hours on rocky, uphill mountain paths. ${ }^{53}$

As it arises from the travelogues, at some point around the end of the 15th century the mountain where Paul resided was linked to the mountain where Zeus lived. ${ }^{54}$ Long before it was linked to the apostle, the island of Crete had been connected to Zeus, the father of the ancient Greek gods. According to mythology, Zeus was born in a cave on Mt Dikti and raised in a cave on Mt Ida. Another cave, this time on Mt Youchtas, was considered to be his tomb. Reading the pilgrims' narratives, it becomes clear that the ancient history of Greece and its many myths were common knowledge. Indeed, very often while travelling through the area of this study, pilgrims refer to places recorded in classical literature. Therefore, the ancient myths connecting Zeus with the island were frequently mentioned in their travelogues. Among the many pilgrims who refer to Zeus, three connect the mountain where the ancient god lived to the

$5^{2}$ William Wey $(1458,1462)$ : ‘[...] fugatus erat per Grecos [...]'. Williams 1857, 57. From the pilgrims who refer to the site throughout the period of this study, almost half of them mention only the mountain top where the apostle, chased by the Cretans, ended up and not the church that existed there: Giacomo da Verona (1335), the writer of Le voyage de la saincte cyté de Hiérusalem (1480), Felix Fabri (1480, 1483-1484), Konrad Beck (1483), Peter Fassbender (1492-1493) and Count Alexander von Pfalz-Zweibrücken (1495-1496) all mention the mountain. Röhricht 1895, 175; Schefer 1882, 5o; Hassler, 1843-1849, vol. 3, 280; Szegzárdi 1916, 69; Röhricht and Meisner, 188o, 252-253; Karbach 1997, 5o. Jean de Tournai (1488), Denis Possot (1532) and Gabriel Giraudet (1555), besides the mountain, also mention a hermitage and the church. Péricard-Méa and Blanchet-Broekaert 2012, 168; Schefer 1890, 131; Giraudet 1583, 20.

53 According to their testimonies, the site was visited by Jacques Le Saige (1518), Nicolas Loupvent (1531) and Gabriel Giraudet (1555). Two of them, Jacques Le Saige and Nicolas Loupvent, describe their itinerary to the apostle's retreat in detail: Duthill $1851,83^{-86}$; Bonnin 1976, 57-59; Giraudet 1583, 20 '[...] darauf ist Jupiter gessössen'. Gaudenz von Kirchberg (1470), Röhricht 1905, 123. 
one where the apostle resided while on Crete. The first one to record this connection of St Paul's hermitage to Mt Ida is the German Dominican friar Felix Fabri (1480, 1483-1484).55

At this point, it should be noted that, when speaking about the church of the Holy Cross and the hermitage of the apostle, pilgrims mentioning them could be referring to three different sites: a summit on Mt Stroumboulas, west of Candia, Mt Youchtas, to its north, or Mt Ida, to its north-west. All three of these sites are mentioned by Cristoforo Buondelmonti, who visited the island at the beginning of the 15 th century (1417-1420). Concerning Mt Stroumboulas, the Italian traveller wrote: 'Outside the said city, a mountain rises round to the sky, on the summit of which stands a church dedicated to the Holy Cross $[\ldots]$,' while he mentions two monasteries located in its foothills. ${ }^{56}$ When writing about Mt Youchtas, Buondelmonti describes a church with three dedications: Christ the Saviour (Ecclesiam Salvatoris), All Saints (Pantonaghion) and St George.$^{57}$ Finally, referring to Mt Ida he mentions a hermitage and a small chapel dedicated to the Holy Cross. ${ }^{58}$ All three of the churches mentioned by Buondelmonti still exist today, the two of them - on Mt Stroumboulas and Mt Ida - with the same dedication, the Holy Cross. In 1443 the church on Mt Youchtas acquired one more aisle and is today dedicated to the Deposition of the Holy Belt of the Virgin. ${ }^{59}$ It becomes clear that, apart from the travelogues that mention the names of the mountain and church, and sometimes even in these cases, it is almost impossible to deduce with certainty to which of the three sites each pilgrim refers.

The summit of Mt Stroumboulas and the church of the Holy Cross, which remains a pilgrimage site to these days and has been linked to the apostle in

55 'Dicunt etiam in hunc montem Idon sanctum Paulum apostolum transfugisse, dum praedicaret ibi insula et quaereretur ad mortem.' Hassler 1843-1849, vol. 3, 28 o.

56 'Extra dictam Civitatem Mons in coelum rotundissimus in Celum erigitur, in cujus cacumine Crucem Sanctam Ecclesiam Magistri hedificavere, aqua circumcirca omnia cernis \& tanquam filios alios sibi adherentes poteris appelare, de Monte paulatim fuit descensus Averni, in quo duo reperimus Monasteria [...].' Cornelio 1755, vol. 1, 95.

57 ' $[. .$.$] in nasum post frontis inquisitionem devenimus in quo tres congestas Ecclesias$ connumeramus; prima harum, quia in tali Monte principaliter Juppiter hic colebatur Ecclesiam Salvatoris hic hedificavere; secunda, quia per multos Deos Mundus regebatur Pantonaghion dicta fuit; Tertia quia Sceptrum Dominii Cretensium antiquis temporibus per Ensem acquisierunt sco. Georgium sanctum stature, in quibus ad consolationem animarum nostrarum Missam celebravi [...].' Cornelio 1755, vol. 1, 97.

$5^{8}$ 'Librum in supercilio Montis Yde heremita legebat dum prope Crucem Sanctam Ecclesiam non magnam sedebat [...].' Cornelio 1755, vol. 1, 104 .

59 The other three chapels were dedicated at the time of Buondelmonti's visit to St George, All Saints and the Christ Saviour, while today they are dedicated respectively to Sts Anargyroi, the Holy Apostles and the Transfiguration of Jesus. Platakis 1970, 311. 


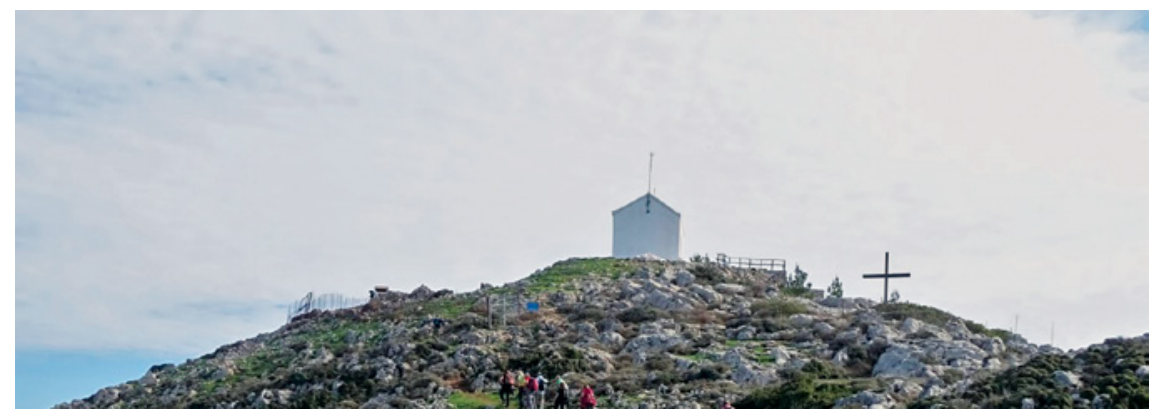

FIGURE 63 The church of the Holy Cross on Mt Stroumboulas

a way that even affected the name by which it was known, would be ideal to identify as the site in question (Fig. 63) ${ }^{60}$ However, the fact that several travellers, including Jacques Le Saige, who visited it in person, mention that on the same mountain one can see the cave where 'Zeus resided', makes this identification questionable.

The French Benedictine monk Nicolas Loupvent, who visited Crete in 1531, could be assumed to be referring to the Mt Stroumboulas, since he describes its characteristic pyramid shape (Fig. 64): '[...] on this mountain, on the summit, is erected a beautiful small and fine Greek church dedicated to the Holy Cross, having enough space for one hermit to reside (if he had something to eat), as well as a small cistern, the water of which is very good to drink [...]. ${ }^{61}$ At the end of the 16th century (1598), another pilgrim, Kristof Harant, also places the church of the Holy Cross at Mt Stroumboulas, since he mentions the neighbouring area of Almiros (al armiro). ${ }^{62}$ The Czech nobleman refers to the mountain as Mt S. Pawel, while he describes a small church, two small buildings without roofs and a hermit residing at the site. ${ }^{63}$

In the following centuries several other travellers mention the small church on the summit of Mt Stroumboulas, attesting to its constant presence in the area. The site's legendary relation to the apostle is also attested in the same

6o Mt Stroumboulas is referred to in several documents, as well as maps of the Venetian period, as monte di San Paolo. Platakis 1970, 306, nn. 32-33, 309, nn. 44-46.

61 The full text reads: 'De la ville de Candie voyt on une haulte montaigne droict a mervelle, en mode de piramide distante dicelle environ $\mathrm{x}$ mil; en laquelle montaigne tout en la sommité dicelle est construicte et érigée une belle petite et jolie esglise grec en lhonneur de saincte Croix, ayant habitation souffisant pour logier ung hermitte (sil avoit la quelque chose a grignoter), et yat une petite cisterne en icelle quest eaue très bonne a boire [...].' Bonnin 1976, 57 .

62 Harant $1608,78$.

63 Harant 16०8, 78. 


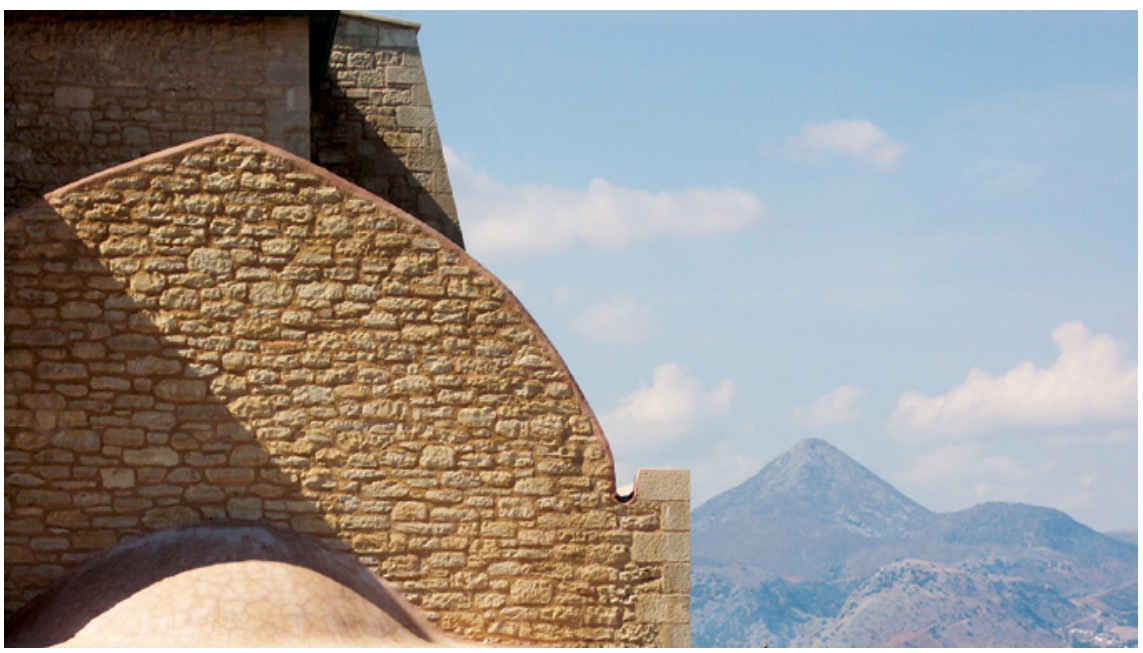

FIGURE 64 Mt Stroumboulas as seen from the Dominican monastery

documents that refer to Stroumboulas as Mt St Paul (monte di San Paolo), as well as in several maps of the Venetian period of the island. ${ }^{64}$ The fame of the site and the habit of walking from the town of Candia to the church of the Holy Cross, a practice that has survived to these days, is attested as well in a report of the Captain and Proveditor of Chania, Filippo Pasqualigo, to the Venetian Senate that, among other matters, refers to a sailor named Lorenzo, who had made a vow to walk all the way up to the church on Mt Stroumboulas. ${ }^{65}$

The Venetian building of the church of the Holy Cross on Mt Stroumboulas is no longer extant, and no archaeological excavations have been carried out in the area in order to establish its exact location, form and architectural type. However, remnants of constructions roughly dated to the 14th or 15th centuries have been observed at the site, where today a modern small chapel with the same dedication stands. ${ }^{66}$ The area is still accessible only on foot and continues to attract pious visitors. ${ }^{67}$

64 Platakis 1970, 306, nn. 32-33, 309, nn. 44-46.

65 ' [...] occorse dopo, che uno di detti marinari, nominato Lorenzo, havendo (come disse) fatto voto di visitar il monte della Croce, procurò di far il viaggio a piedi'. Published in Platakis 1970, 305 .

66 The site has not been thoroughly studied or excavated. The aforementioned information about the church's dating was provided by the Ephorate of Byzantine Antiquities of Heraklion.

67 Even today, the church can be accessed only on foot. A road leads to a point quite near the summit where the chapel is located, but a walk of almost an hour is still required in order to arrive at the site. However, many visitors choose to follow the same route the pilgrims did, and excursions from Heraklion are often organised. A public religious celebration 
The church on the summit of Mt Youchtas is not clearly referred to by any pilgrim. The mountain, with its characteristic outline that looks like the face of a reposing man and according to the local tradition is the head of Zeus, was additionally linked to the Greek god by the cave located on its side, considered to contain his grave.

At the beginning of the 16th century, in 1518, Jacques Le Saige mentions visiting St Paul's hermitage and the church of the Holy Cross while in Candia. As described in his narrative, he left the town right after dinner, along with five of his companions and a hired local guide. They spent the night at a village on their way, arrived at the site early in the morning and were back in Candia by noon. If one accepts that the description of the itinerary of the French pilgrim is accurate, and given the distance and altitude of the summit, it would not be possible for him to have visited the church on Mt Ida in such a short period of time. It seems more probable, since he clearly states seeing the place where Zeus lived, that the company of pilgrims visited a spot on Mt Youchtas. ${ }^{68}$

However, the identification of the church still existing on Mt Youchtas, the one described by Buondelmonti, with the hermitage the French pilgrim describes seems rather improbable. By the 16th century the church in question had four aisles and, respectively, four dedications; however, none was to the Holy Cross (Figs 65a, 65b). On the other hand, the church visited and described by Jacques Le Saige was a poor, small building. It seems that the most plausible hypothesis is that either he and his companions visited a church on Mt Youchtas that has not survived to these days; or they went to the church of the Holy Cross on Mt Stroumboulas, assuming in this case that the travellers misunderstood the legend with the cave were Zeus used to live or that there was a now-lost tradition relating the mountain with the ancient Greek god.

Whatever the case may be, the French merchant conveys valuable information concerning the church of the Holy Cross. According to his narration, the chapel was very small and poor, and two Greek hermits resided there. He also appears to complain about the fact that there was no provision for the necessary liturgical objects for the performance of a Latin mass. ${ }^{69}$ Continuing,

takes place at the site twice a year, on 20 July and 14 September, and attracts a significant number of pious visitors.

68 ' $[. .$.$] ung petit lieu le devanture bien taillies et machonnee ou il y avoit des belles fenestres$ croysies [...] ou Jupiter se tenoit'. Duthill 1851,85 .

69 'Lhermitaige est bien poure et se tient deux hermites; lung estoit prestre grecq et nont point d'aultre livre. Et se navoient point de hostie ne aultre chose propice a dire messe a nostre mode. Se fust nostre prestre trompes, car il n'avoit oses mengier.' Duthill 1851, 85. As already mentioned in the case of the church of the Virgin in Kassiopi, a great number of pilgrims report celebrating the, obviously Latin, mass in front of the icon. It seems that in the Corfiot church, the local community and clergy ensured that pious Western travellers had the permission and the necessary liturgical implements to perform their liturgies in 


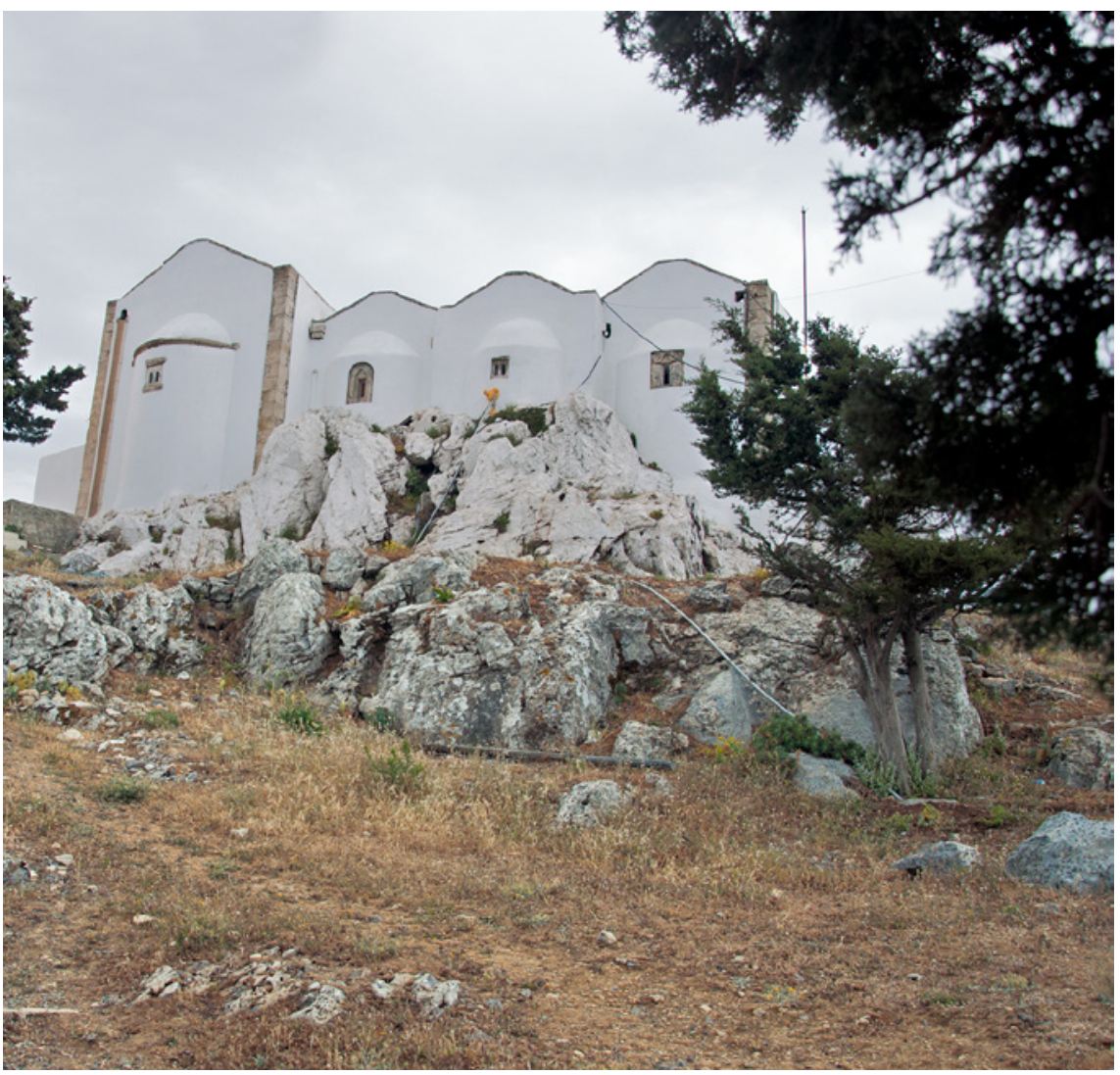

FIGURE 65a The church on Mt Youchtas, view from the east

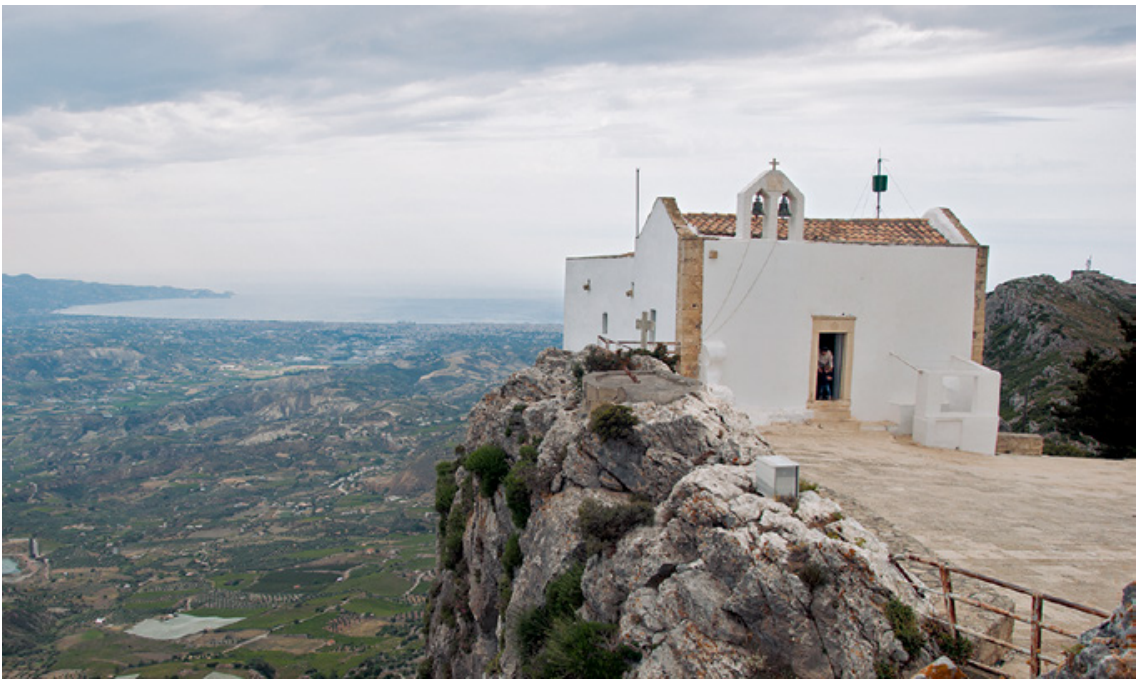

FIGURE 65b The church on Mt Youchtas, view from the north 
he offers the only, and thus very precious, pieces of information surviving in the travelogues concerning the interior of the church: There is nothing in this place besides two images of the Virgin and of saints painted on the walls, very old. I have not seen such in our country.70 Summing up, the church of the Holy Cross Jacques Le Saige describes was a single-cell chapel, in all probability Greek Orthodox, served by two hermits living on the spot. It was decorated with frescoes on the walls, obviously in the Byzantine manner, depicting the Virgin and portraits of saints, and was considered an important pilgrimage site by both the Greeks and the Latins.

Concerning the summit of Mt Ida, only one pilgrim makes a direct mention to it, relating it to the apostle: the German Dominican friar Felix Fabri (1480, 1483-1484), who mentions that "They say that at this Mt Ida St Paul the Apostle had retreated. ${ }^{71}$ Over half a century later the Czech pilgrim Oldřich Prefát (1546-1547) refers to a small church on Mt Ida, without however stating its dedication. ${ }^{72}$ The identification of the church mentioned by the pilgrims with the church of the same name on the highest summit of Mt Ida would be quite reasonable, given the connection of Mt Ida with Zeus (one can still visit the cave where according to the myth Zeus was raised) and the dedication of the church that according to Buondelmonti stood there since the beginning of the 15th century. Nevertheless, the fact that several pilgrims mention that the site was not far away from the town raises questions in regard to its

it. Such a practice - the performance of liturgies of both rites in the same church, as seen also in other churches of Corfu, Modon and Crete - is probably the reason why it came as a surprise to the pilgrims that the necessary provisions were not made in the church of the Holy Cross as well.

70 'Il ny a audit lieu que deux ymaiges de nostre dame et des saincts painte contre les parois bien vieses. Je ne vis oncques de sy faicte en nos pais.' Duthill 1851, 85 .

71 See $n .55$ above. In 1470 the German pilgrim Samuel Kiechel also mentions a mountain where Zeus lived and a church at the site where the apostle resided after being chased by the locals. However, it is not clear from his writing if those two sites are on the same mountain. Hassler 1866, 20.

72 The text reads: 'Od města pak asi pět mil vlaských, to jest míli českau, leží vysoký vrch velmi $\mathrm{k}$ západní straně města a neviděl jsem vyššího v tom ostrově ve všem; jest nahoře špičatý co homole a slove vlasky, jak mi pravili, Monte Ida; mám za to, že to ten vrch mons Ida, na kterým jest odchován Iupiter, o čemž poetové píší. Nyní na tom vrchu jest malá kaplice neb kostelík.' [Five miles to the west of the town of Candia, that is one Czech mile, there is a high hill; I have not seen a higher one on the island. The mountain is pointed and, as they told me, is called Mt Ida; I think it is the same Mt Ida where Zeus was brought up, the one about which poets write. Today on the mountain there is a small chapel or church.] Hrdina 1947 (2014), 79. 
identification, due to its distance from Candia and the altitude of the summit where the church is built $(2453 \mathrm{~m}){ }^{73}$

The small church standing today at the site, a single-aisled building, constructed with rocks from the area and without binding material is not the 15th-century chapel Buondelmonti described (Figs 66a, 66b). However, its size and form, as well as the surrounding rocky landscape, fit the pilgrims' descriptions. Due to its connection to Zeus, the mountain has been considered holy since the ancient period. The aforementioned, combined with the extremely evocative landscape, make the highest summit of the mountain an ideal 'holy site', although its altitude renders it hard to reach and thus to become a popular pilgrims' destination. ${ }^{74}$ At this point, it should be mentioned that the French priest Nicolas Loupvent (1531), while stating that he went to 'a pyramid-shaped mountain near the town of Candia', thus considered to have

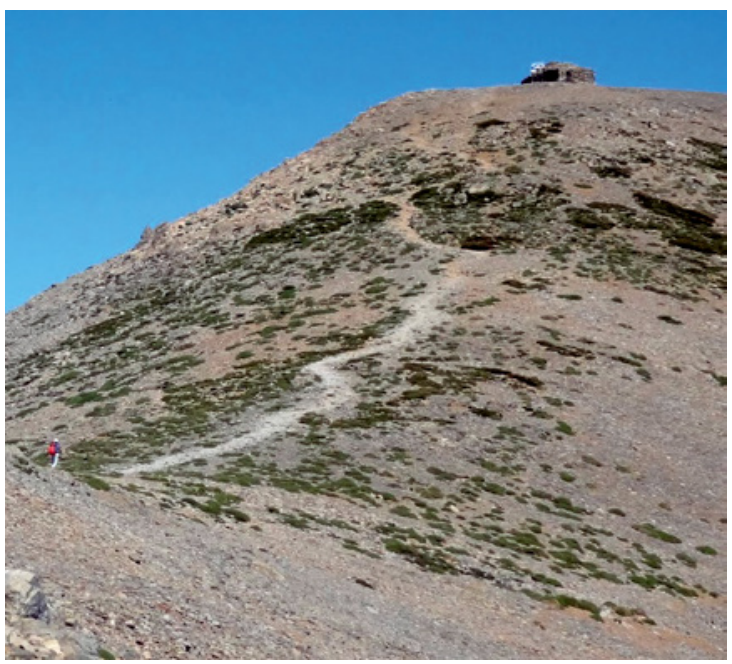

FIGURE 66a The climb to reach the church of the Holy Cross on Mt Ida

73 Count Alexander von Pfalz-Zweibrücken and Johann Ludwig von Nassau-Saarbrücken (1495-1496): 'Bei Candia'. Karbach 1997, 5o. French anonymous (1480): 'prés de Candie'. Schefer 1882,52 . Some of the pilgrims mention the church's distance from the town, but the divergence between their testimonies makes it difficult to rely on them. Nicolas Loupvent places it 10 miles away from Candia, Jan Hasištejnsky 5-6 miles, Gabriel Giraudet 2 leagues, Samuel Kiechel 10 miles. Bonnin 1976, 57; Strejček 19o2, 32; Giraudet 1583, 20; Hassler 1866, 2 o.

74 Despite its high altitude and the fact that it is still accessible only on foot, the site continues to attract religious visitors, while every year on 14 September the Exaltation of the Holy Cross is celebrated at the small church. 


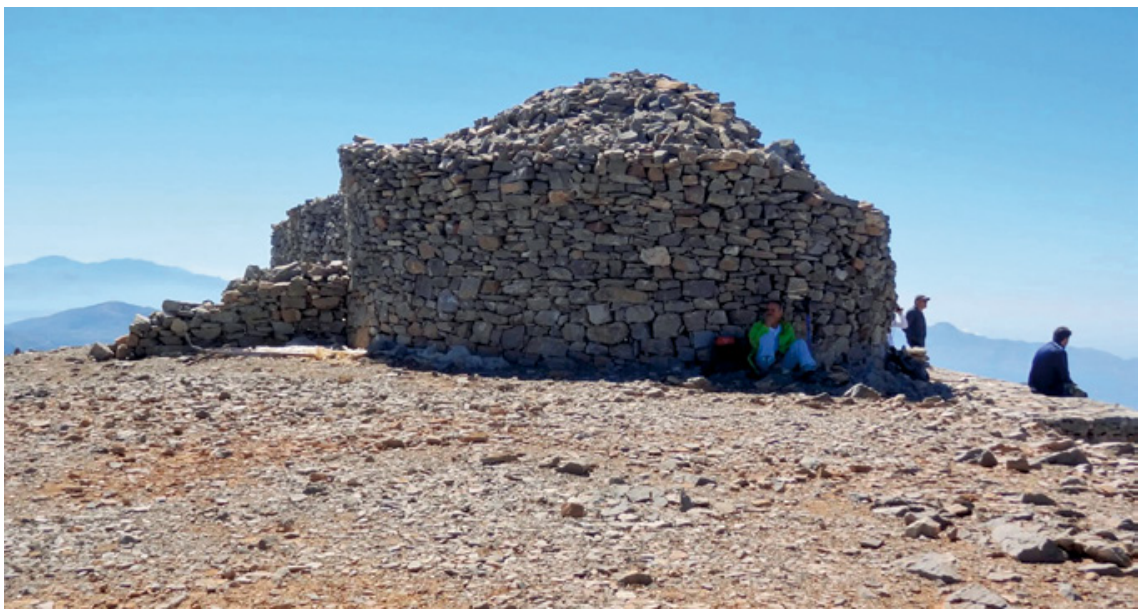

FIGURE 66b The church of the Holy Cross on Mt Ida

been on Mt Stroumboulas, is the only one of the pilgrims who visited the site that could be placed on the summit of Mt Ida, since he describes an itinerary that lasted almost three days and an extremely difficult ascent to 'the highest and most eminent place of the kingdom of Crete. ${ }^{75}$

As far as the rest of the narratives mentioning the church of the Holy Cross are concerned, they refer to a small chapel on top of a mountain, not providing any further information that could help the identification of the spot, while two pilgrims, Peter Fassbender (1492-1493) and Jacques Le Saige (1518), write about a connection of the mountain with Zeus. ${ }^{76}$ Some of the pilgrims, as they often do, mention the church's distance from the town: they speak about 5 or 6 French miles, 2 French leagues or 10 German miles, thus excluding Mt Ida, at least in the first two cases and if one accepts their accuracy. ${ }^{77}$ Two Swiss travellers of the 17th century, Johannes Habermacher and Wolfgang Stockman, who visited Crete in 16o6, both place the church at 'Mt St Paul' (Mt Stroumboulas) and describe it as a small church, next to which was a small 'open house' (most probably the roofless building described by Kristof Harant in 1598) for the accommodation of the pilgrims. What is interesting in the Swiss pilgrims' narratives is the fact that they both distinguish 'Mt St Paul' from Mt Ida. ${ }^{78}$

75 '[...] le plus hault lieu et éminant du réaume de Crète'. Bonnin 1976, 58.

76 Röhricht and Meisner 188oc, 252-253; Duthill 1851, 85 .

77 See $n .73$ above.

$7^{8}$ Schmid 1957b, 177; Schmid 1957c, 341. 
It is clear from all the surviving descriptions of the site that there was nothing impressive or elaborate about the building or the decoration of the church. Furthermore, there does not seem to have been any special provision for the accommodation and the liturgical needs of the pilgrims who decided to visit it, facts that, combined with its location and altitude, forestalled its becoming an eminent pilgrimage site. ${ }^{79}$ Hence, it appears that the site owed its holiness and fame to the apostolic connotations attached to it and the especially evocative surrounding landscape, as one can still see today in all three churches. Its uninterrupted presence in the travelogues and the fact that a number of travellers decided to undergo the hardship of walking to it could be used as an attestation of the site's importance and its fame among the pilgrims visiting Crete, leading to it surpassing its regional character and allowing its insertion into the network of the holy sites dotting the way to Jerusalem.

Summing up, given the persistence of the pilgrims on the church's dedication and unless there was a chapel dedicated to the Holy Cross on Mt Youchtas that is no longer extant, it would be plausible to assume that the narratives could be referring to two different sites: Mt Stroumboulas and Mt Ida. While the latter is by any means more imposing and has a long history of 'holiness' attached to it, both have the qualities of a prominent pilgrimage site, hence they continue to be treated as such to today. In the end, to whichever mountain the pilgrims were referring, the small chapel on a high rocky summit with a breath-taking view amplifying its sacredness and - most importantly - the site's relation to the apostle are reason enough to explain its constant presence in the travelogues and to render it as an important pilgrimage site for both Greeks and Latins. ${ }^{80}$

\subsection{The Church of Santa Maria dei Miracoli}

Around the end of the 15th century, more specifically in the year 148o, two French co-travellers, Pierre Barbatre and the anonymous author of Le voyage de la saincte cyté de Hiérusalem, write about a small Greek church and the miracles related to it:

Outside the town, in front of the gate, there is a small chapel dedicated to the Virgin; and it is known that five years ago the council of the town

79 In 1598 the Czech writer Kristof Harant refers to a roofless building standing at the site for the accommodation of the pilgrims. Harant 1608,78 . The same information is also conveyed about a decade later by the Swiss traveller Wolfgang Stockman (1606), who mentions an 'offen hus'. Schmid 1957b, 177; Schmid 1957c, 341.

8o Samuel Kiechel (1470): ‘[...] ein grose wallfart dohün geth von Grüechen unnd Ittalianern'. Hassler 1866, 443. 
wanted to demolish the houses of the area to fortify and enhance the walls and the moats of the city; but when the time came to demolish the altar where the icon of the Virgin was placed, none of the people of the town, not even the builders, could nor damage nor destroy it, and it is now the most 'holy' place of the town. And many miracles are performed there such as: blind, deaf, mute and sick, and men fighting against the Turks are saved by their devotion to this church. There are canon priests there, who officiate and perform the canonical hours in Greek. ${ }^{81}$

The small church was mentioned again in four travelogues: the narration of the journey of Jean de Tournai (1488-1489) and the travelogues of Pietro Casola (1494), Jacques Le Saige (1518) and Denis Possot (1532).82 As described by the pilgrims, the church, named as Santa Maria di Piazza (Пavajía tov Фópov), Santa Maria dei Miracoli or the Madonnina, became known when, during construction works for the reinforcement of the fortification of the town, the authorities tried to demolish it, but its demolition was miraculously prevented; and thereafter the Virgin 'rewarded' the town with a number of miracles. ${ }^{83}$

Located in the modern 1821 Street, during the Venetian period the church was right outside the city walls to the south, next to the Porta di Voltone. The two French 16th-century pilgrims refer to the church of the Virgin as an Orthodox institution, but the fact is that it appears in both the catalogues of

81 Pierre Barbatre (1480): 'Au dehors devant la porte est une petite chappellete de Nostre Dame et est certain que depuis $\mathrm{v}$ ans on a voullu abatre toutes les maisons d'en pres comme a esté faict par le conseil des segnieurs pour fortiffier et croistre la muraille et fossés de la cité; maiz quant est venu pour abatre le lieu ou estoit l'autel sur lequel est une ymage de Nostre Dame en paincture, toulx ceulx de la ville, massons ne aultres n'ont peu mal faire ne abatre ledit lieu, maiz est de present le plus devot lieu de toute la cité. Et la ce font plusieurs miracles comme: aveugles, sours, muez, malades guaris, et gens en guerre sur les Turcqs salves par la devocion qu'ilz ont audit lieu. En ce lieu sont prebstres chanoines lesquieulx font le service et dient les heures canoniales en grec.' Pinzuti and Tucoo-Chala 1972-1973, 123 .

82 Pietro Casola (1494), see n. 85 below. Jacques Le Saige (1518): 'Après estés la une espasse allasmes a une eglise hors de la porte sur soleil de midy; elle est en lhonneur de nostre dame laquelle faict pluseurs miracles. Et mesmes nous fut dict quon vollut abattre une fois pour faire la les fossés pour fortifier la ville; mais on ne poeult. Nous y arrivasmes en ladite eglise ainssy que on commenchoit la messe en grecq.' Duthill 1851, 81. Denis Possot (1532): 'Toutes les eglises de Grecz en icelle isle ont estè destruictes excepté les religions et aulcunes qui sont près des villes du costé vers midy qui ont esté laissées pour la deffense de Candie et une chappelle de la Vierge Marie laquelle a esté miraculeusement deffendue, tellement qu'on ne la peult destruire, en laquelle par chascun jour, on dit les heures canoniales.' Schefer 1890, 129 .

83 About the church of the Virgin, see Georgopoulou 2001, 174-175, 188-189; Starida 2016, 145; Gerola 1908, 157 . 
the Orthodox and the Latin churches. In particular, in the catalogue of the churches of the city of Candia of Vincenzo Maria Coronelli, it is characterised as a church that is 'half Latin and half Greek.' ${ }^{84}$ The Italian pilgrim Pietro Casola corroborates this: 'Outside the gate leading to the borgo stands a beautiful church of the Virgin: it is governed by Greek priests, who are called calogeri; however, they also perform masses in Latin there. ${ }^{85}$

The church appears in 1482 in the will of Donatus Grioni, while in 1499 it seems that Venetian noblemen were acting as its procurators. ${ }^{86}$ However, a few years earlier, in 1492, the Madonnina was recorded as a Greek Orthodox institution. ${ }^{87} \mathrm{~A}$ report of the Latin archbishop in 1625 stated that it had two altars, one for the Orthodox and one for the Latins. ${ }^{88}$ Almost half a century before the archbishop, the French pilgrim Jean de Tournai (1488) attested to the existence of two altars in the small church of the Madonnina; more precisely, he witnessed a Greek priest performing the liturgy at the Orthodox altar, located behind the icon, while he mentions another Latin altar situated in front of it. ${ }^{89} \mathrm{He}$ is also the only pilgrim who attributes the miraculous icon of the Virgin to the Evangelist Luke. ${ }^{90}$

The location of the two altars in the church of the Madonnina as described by de Tournai brings to mind the arrangement proposed in 1627 by the Governor of Crete, Francesco Morosini, in regard to the church of the Saviour in Ierapetra in order for it to serve as a double-rite church. In the case of the latter, Morosini suggested the use of two altars, one for the Orthodox and one for the Latins, a scheme that according to his statement was known and applied in other churches of the island. In fact, he mentions a Latin church in the village of Kato Episkopi, where the Orthodox altar was located in its original place,

84 'Chiesa mezz'Italiana e mezza Greca'. Starida 2016, 146. The church of the Madonnina is included in a list of 1548 of Orthodox churches. Georgopoulou 2001, 188; Starida 2016, 146, n. 451.

85 'A l'uscire de la porta, che va in dicto borgo, egli una bella devotione de Nostra Dona: è governata per preti Greci, quali domandano loro calogeri; pur se li dicono ancora de le messe latine.' Paoletti 2001, 151-152.

86 Georgopoulou 2001, 188, n. 95 .

87 Georgopoulou 2001, 188; Gerola 1918, 246.

88 Georgopoulou 2001, 188, n. 97; Panagiotakes 1987, 107.

89 'Laprès-midi, je retournai à la chapelle Notre-Dame. Derrière l'image est un autel appartenant aux Grecs. Il y avait de la place et un Grec sonnait les vêpres. Je demandai au Cordelier qui gardait la place pourquoi il y avait deux autels l'un derrière l'autre, il me répondit que c'était à cause d'hérésies qui seraient trop longues à raconter.' Péricard-Méa and Blanchet-Broekaert 2012, 168.

90 'Je passai la porte au-delà du marché jusqu'à une petite chapelle où est un autel des latins avec une très belle image de Notre-Dame peinte par saint Luc. Nous tous, les pèlerins, y avons entendu la messe.' Péricard-Méa and Blanchet-Broekaert 2012, 167. 
inside the bema and behind the templon, while the Latin one was placed right in front of it. The view to the Orthodox altar was blocked during the Latin liturgy by a large icon, which was moved when the liturgy was performed by the Orthodox priests, who used the lateral doors. ${ }^{91}$ The governor's suggestion is accompanied by a drawing that shows the proposed arrangement. ${ }^{92}$ Given that this plan concerned moving structures, the scheme cannot be archaeologically confirmed. However, the French pilgrim's description of two altars located 'one behind the other' could suggest the employment of an analogous arrangement in the church of the Madonnina during the 15 th century.

The exact date of the construction of the church of the Virgin has not been determined with certainty. After its demolition in the 196os and the excavation that followed, an underlying building of the second Byzantine period of the island came to light. ${ }^{93}$ The Venetian Madonnina was a three-aisled basilica, with an elevated central nave that created a clerestory, pierced by five pointed arch windows (Fig. 67) ${ }^{94}$ There were also pointed arch windows at the east end of the church. The aisles were separated by square piers, which supported round arches, while there was no apse to the east marking the sanctuary. The building was covered by a sloping timber roof. ${ }^{95}$

As already mentioned, the Madonnina was in all probability a double-rite church, with an Orthodox as well as a Latin altar to cover the needs of both confessional groups. After the end of the Venetian period of the town and its occupation by the Ottomans, the church was converted into a mosque, the Reishub Kuttab Hazi Hussein Efendi Cami (Fig. 68). ${ }^{96}$ Later on, around 1898, it was used as a covered market, where the stalls were housed in the two lateral naves. The building was demolished in the 196 os. $^{97}$

Although the Madonnina appears in only a few travelogues, pilgrims' references to it are quite detailed for such a small and seemingly unimportant monument. It becomes clear that around the time of the two French pilgrims' visit (1480), the legend of the small church and its miracle-working icon was

91 About the church of the Saviour at Ierapetra, see Papadaki 2009; Gratziou 2010, 168-172. About double-rite churches, their interior arrangement and the architectural solution developed for the use of one church by both rites, see Gratziou 2010 172-183.

92 The drawing of the interior arrangement proposed for the church of the Saviour in Ierapetra is published in Papadaki 2009, 239.

93 Starida 2016, 146; Georgopoulou 2001, 188.

94 Georgopoulou 2001, 174; Gerola 1908, 157.

95 Georgopoulou 2001, 174-175; Gerola 1908, 158.

96 Starida 2016, 146, 209; Georgopoulou 2001, 189; Gerola 1908, 157.

97 Georgopoulou 2001, 188-189; Gerola 1908, 158; Starida 2016, 146, 209. 


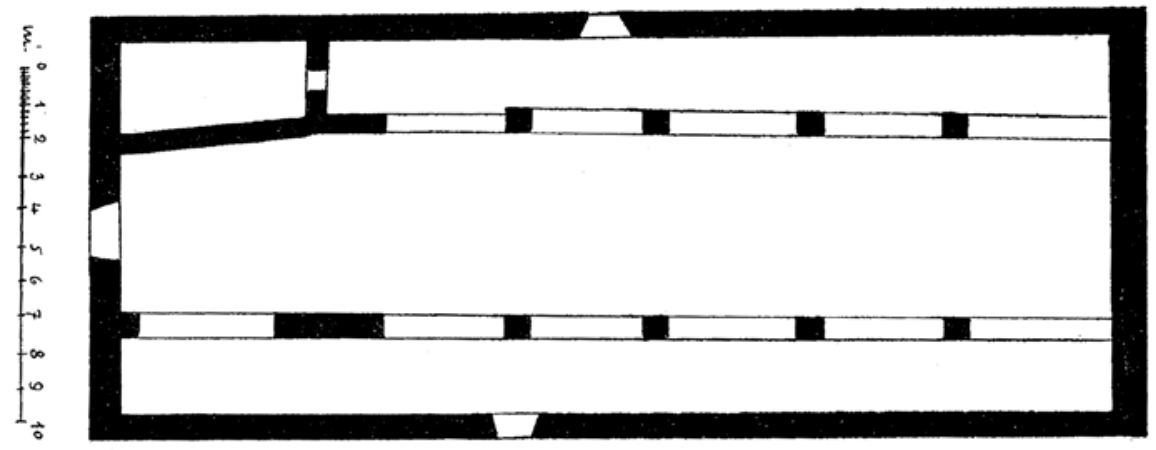

FIGURE 67 Plan of the church of Santa Maria dei Miracoli, Candia

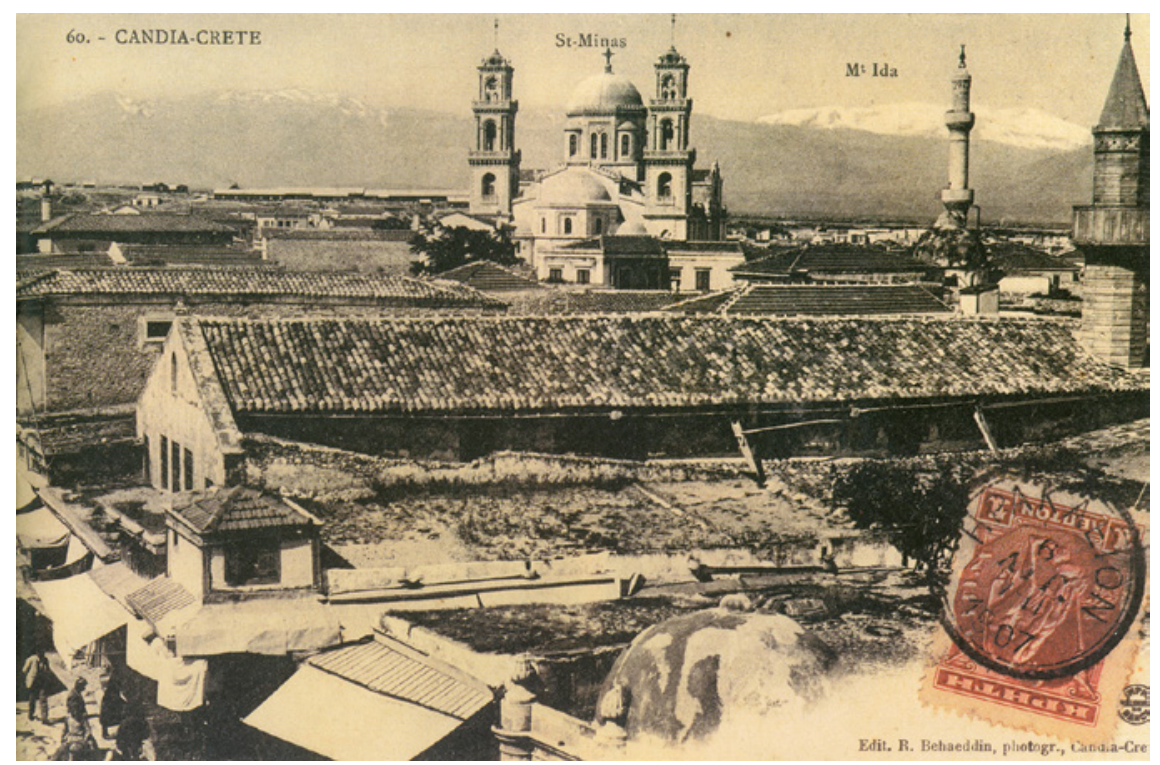

FIGURE 68 The church of Santa Maria dei Miracoli, Candia, as a mosque, c. 1907

circulating in the city of Candia and was obviously transmitted to the foreign visitors. Thus, the fact that all the mentions to the church of the Madonnina appear in the late 15th century and the 16th reflects a certain increase in its fame during this period, related to the miracles performed by the Virgin as attested in the narratives. In this manner, the importance of the church of the Madonnina, as revealed by the travelogues referring to it, was amplified, since it arises as another Marian cult site of the town, venerated by Latins and Orthodox alike. The city of Candia showed a special devotion to the Mother of 
God and was proud to possess several miraculous icons of the Virgin, including its most celebrated palladium of the Virgin Mesopanditissa. ${ }^{98}$

\subsection{The Church of St Titus, the Latin Cathedral of Candia}

As far as the Latin churches and monasteries of Candia are concerned, it is the town's cathedral and its renowned Franciscan monastery that amass the largest number of references in the travelogues. Apart from those, pilgrims also refer to the Dominican and Augustinian monasteries, while the Latin churches of St Mark and St Rocco are sparsely mentioned. In the borgo there was also a Benedictine establishment, a Servite monastery dedicated to St Paul and two hospitals with churches, the aforementioned hospice of St Anthony and St Maria of the Crusaders, which also appear sparsely in the travelogues. Unlike Modon and Corfu, Candia's Latin churches pleasantly surprised the Western visitors, since they seemed, aesthetically and architecturally, to approach forms and shapes familiar to Westerners. The cathedral, the mendicant monasteries and principally the church of St Francis were elaborate and impressive institutions that became poles of attraction for locals and visitors alike.

The cathedral of Candia, dedicated to the island's patron saint, St Titus, existed in the town prior to its occupation by the Venetians. It was located in the east of the main street (ruga magistra) leading from the port to the walls and the borgo, near the marketplace, the ducal palace and the square where later on the Venetian church of St Mark was erected (Fig. 69). Adjoining the church was the archbishop's palace, which was appropriated by the Venetians along with the cathedral for the use of the Latin archbishop. ${ }^{99}$

The cathedral's exact date of construction is uncertain, but it was most probably built soon after the moving of the island's capital from Gortyna to Chandax (present-day Heraklion) by the Emperor Nikephoros Phokas during the second Byzantine period of Crete. ${ }^{100}$ Ever since its erection and until the town's occupation by the Ottomans in 1669 , the church served as the cathedral of Byzantine Chandax and subsequently Venetian Candia. ${ }^{101}$ It should be pointed out that, as supported by Maria Georgopoulou, the original dedication

98 Besides the Latin cathedral of the town, where Candia's palladium, the Lucan icon of the Virgin Mesopanditissa, was kept, all three conventual churches of the major monastic orders, the Franciscans, the Dominicans and the Augustinians of the town, are attested to have housed, at least at some point in their history, a Byzantine or Byzantine-style miraculous and/or Lucan icon of the Virgin.

99 Xanthoudides 1964, 24; Georgopoulou 2001, 109.

100 Kritsotaki 1995, 347; Georgopoulou 2001, 109; Xanthoudides 1964, 24; Andrianakis and Giapitsoglou 2012, 81 .

101 Kritsotaki 1995, 347; Georgopoulou 20o1, 109; Xanthoudides 1964, 24. 


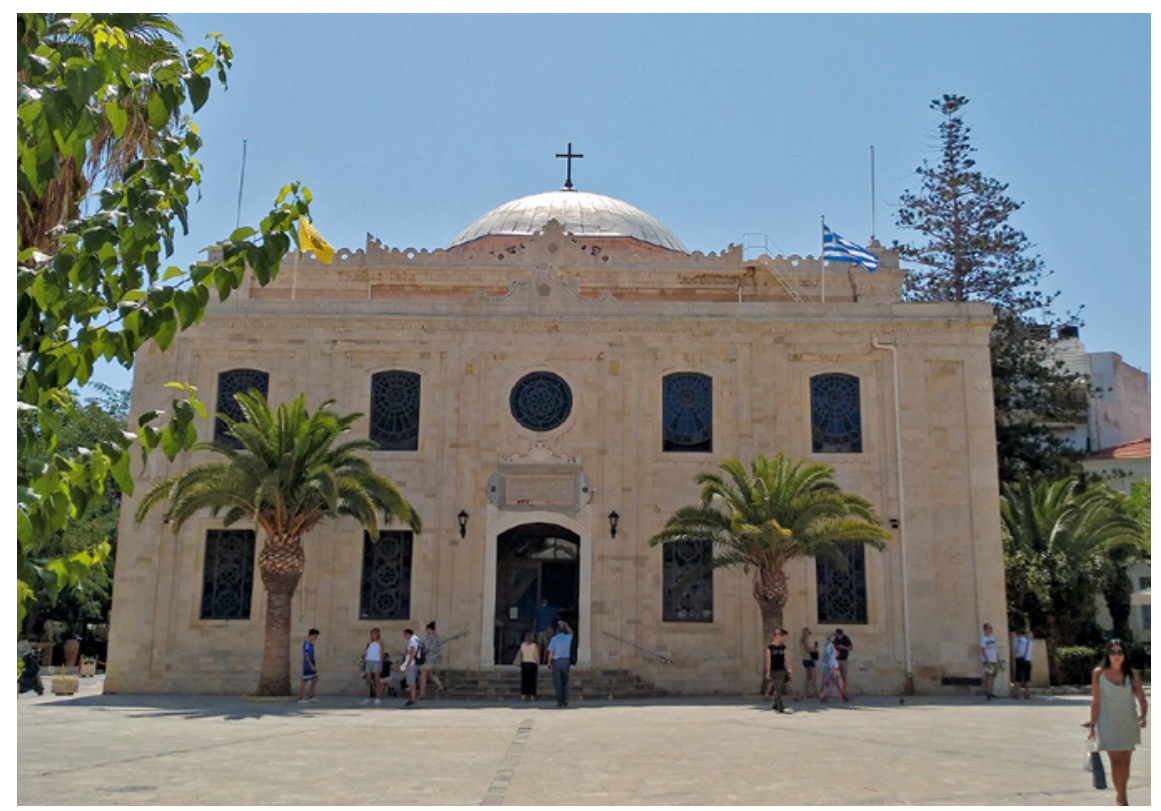

FIGURE 69 The church of St Titus, Heraklion

of the Orthodox cathedral of Chandax was not to St Titus, but to All Saints. Accordingly, the cathedral either had two dedications or was rededicated to St Titus following the translation of the saint's relics or after its appropriation by the Venetians. ${ }^{102}$ As in most of the cases of Venice's occupied territories in Greece, following Candia's occupation the cathedral, along with the relics held in it, was seized by the new rulers and converted for the use of the Latins.

The actual form of the Byzantine cathedral has not been determined with certainty. Based on a depiction by Cristoforo Buondelmonti dated to 1429, Niki

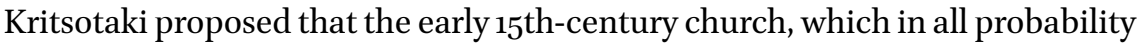
was the Byzantine one, was a one-aisled basilica, while she considers the bell tower showing at the south-east corner to be an addition to the building after its appropriation by the Venetians. ${ }^{103}$ It has been suggested that the church was destroyed and rebuilt in the first half of the $15^{\text {th }}$ century as a three-aisled basilica, although there are no records of large-scale restoration works carried out during the Venetian period. ${ }^{104}$

102 Georgopoulou 1994, 111; Georgopoulou 2001, 109.

103 Kritsotaki 1995, 347.

104 Kritsotaki 1995, 347-348; Gerola 19o8, 41, n. 1; Georgopoulou 2001, 112; Georgopoulou 1995, 109. In fact, Maria Georgopoulou proposes that the rebuilt church of 1446 suggested by 
In regard to the Latin cathedral's architectural plan and since the church standing today is a building of 1925, we can rely only on documents and depictions. Given its Byzantine origins, it would be quite safe to deduce that the building ended in a - probably vaulted - apse at the east. ${ }^{105}$ Despite the lack of documentary evidence concerning a possible extensive reconstruction of the building after the town's occupation by the Venetians, it can be safely assumed that the appropriation of an Orthodox church by the Latins would lead to significant changes in the liturgical layout of its interior, mainly by creating new chapels and multiple altars. ${ }^{106}$ According to the custom, wealthy patrons, dukes and archbishops were buried in the cathedral, thus new, elaborately decorated altars would have been added to the church. ${ }^{107}$

A 14th-century document indicating the existence of a dome could lead to the assumption that St Titus was a domed basilica: in 135 o Heregina Asoleis agreed an indenture to build a church that according to her wish should be adorned with a dome 'built the same way as the one of the church of St Titus'.108 The building had its main entrance to the west, a large tripartite opening, as well as one to its south and one to its north side, leading to the archbishop's palace. ${ }^{109}$ As can be deduced from written sources, in the 16th century the

Giuseppe Gerola was actually a reconsecration of a new altar, created when the axial chapel was removed to house the tomb of Archbishop Fantinus Vallaresso. She also cites the part of the document that reads: 'consecratum fuit hoc altare in honorem'. Georgopoulou 2001, 112, n. 5 .

105 The Byzantine origins of the church of St Titus are asserted by a document of 9 March 1670 by the former vicar of the Latin cathedral of Candia, Angelo Venier: 'La Chiesa preditta di S. Tito fu antichissima metropoli di Candia fabricata da Constantinopolitani et posseduta nel ritto Greco per lungo tempo, pervenuta poi nel rito latino coll'aquisto del Regno da questa Serenissima Republica sotto l'anno 1204 senza mutar il titolo di essa chiessa.' Theochari 1961, 279; Georgopoulou 2001, 112. About the possible architecture of St Titus, see also Newall 2016, 116.

106 Maria Georgopoulou suggests, as a parallel of the gradual transformation of a uniform space divided in two by a templon into a series of private chapels surrounding the stalls of a choir, the cathedral of Negreponte. Georgopoulou 20o1, 112, nn. 6-8. The aforementioned church has now been identified as the conventual church of the Dominicans of Chalkis. See MacKay 20o6; Delinikolas and Vemi 2006.

107 Archival documents provide information about the chapels in the church of St Titus: three large chapels around the choir and four smaller ones at the north and south sides of the building were erected in the $15^{\text {th }}$ century, while in 1467 there must have been at least eleven chapels in the cathedral. Franciscus Mudiano built a chapel dedicated to St Francis before 1463 and Leonardus Mazamano endowed a chapel in front of his family grave in 1473. Georgopoulou 2001, 113, n. 10; Kritsotaki 1995, 347; Panagiotakis 1984, 116.

108 Georgopoulou 2001, 113, n. 17 .

109 A surviving description of 1662 of a ceremony that took place in the cathedral attests to the existence of the these entrances: 'entrando in stesso tempo in essa (la chiesa 
central doorway was surmounted by a circular arch supported by lateral colonettes and topped by inscriptions. ${ }^{110}$ The church also had a bell tower, as is clearly depicted in all views of Candia (see Figs 6o, 61). ${ }^{111}$

Ever since its appropriation by the Venetians and until the end of the Venetian occupation of the island, St Titus remained the cathedral of Candia. During its Venetian history the church suffered damage from earthquakes, such as in 1508 , while on 3 April 1544 it was almost destroyed by fire. After the occupation of the town by the Ottomans in 1669, the former Latin cathedral was turned into a mosque, the Vezir Cami. It was destroyed by the earthquake of 1856 and was rebuilt in 1925, when it was reconsecrated as an Orthodox church. ${ }^{112}$

The cathedral of Candia housed, at least since 1211, the relics of the island's patron saint, St Titus. The saint's cult, deeply rooted on Crete by the time of the Venetian's arrival, was appropriated by the new rulers and incorporated into the sacred hierarchy of Venetian Crete. Following their religious policy, the Venetian rulers of Candia used the local saint's cult as a link between the inhabitants of the Latin and Orthodox rites, but also as a sanctifying power of their authority. It is worth mentioning that the cult of St Titus and the veneration of his relic were never as strong and elaborate as during the period of the Venetian occupation of the island.

During the Venetian period the palladium of the city, the miraculous icon of the Virgin, known as 'Mesopanditissa', was kept in the cathedral. ${ }^{113}$ The Byzantine icon of the Virgin, attributed to the Apostle Luke, was considered to be miracle-working and was probably the most venerated object in Candia. Soon after the occupation of the island, its cult was incorporated by the Venetians into their religious customs, and when the island succumbed to the

cattedrale) tanto Monsignor Illustrissimo Arcivescovo per la porta cha passa nel cortile et coridoio arciepiscopalle, quanto li studetti Rapresentanti per le alter porte di detta chiesa ... Et doppo finita la funcione ... viene acompagniato detto detto Monsignor Illustrissimo Arcivescovo dalli Rapresentanti vicino alla porta suddeta del cortille dall quale poi si licenciano.' Kritsotaki 1995, 349; Georgopoulou 20o1, 114, n. 22.

110 Georgopoulou 2001, 112.

111 The bell tower that in Buondelmonti's depiction of 1429 is placed at the southeast corner of the building is positioned at the southwest in later depictions (in the maps by Corner [1625] and Werdmüller [1668]). It could be assumed that it was moved to make way for several annexes built at the southeast side of the cathedral. The Venetian bell tower most probably served as the minaret of the mosque that succeeded the Latin cathedral and is believed to have been five storeys high, square in form and, by the 16th century, covered by a cupola. Kritsotaki 1995, 349; Georgopoulou 2001, 114-115, n. 23.

112 Kritsotaki 1995, 348-350; Georgopoulou 2001, 111-112; Detorakis 1970, 26-28; Xanthoudides 1964, 24, 58 .

113 Georgopoulou 2001, 109; Andrianakis and Giapitsoglou 2012, 81. 
Ottomans the icon was taken to Venice, where it is still celebrated in the church of Santa Maria della Salute. ${ }^{114}$ Aside from the icon, and among other relics, the head of St Barbara, a crystal reliquary with the blood of Christ, the arm of St Ephraim and a piece of the tibia of St Sabbas were also kept in the cathedral, while relics of St Titus, St Martin, St Lucy and St Stephen were placed at the new altar erected above the tomb of Archbishop Fantinus Vallaresso in $1446 .{ }^{115}$

Pilgrims' narratives, as expected, often mention the Venetian cathedral. Most of the references to the church of St Titus are in relation to the saint's head, as well as the other relics kept and venerated in it. It is important to note that Crete, and by extension Candia's cathedral, had been invested with indulgences already from 1209 by Pope Innocent III. ${ }^{116}$ However, oddly enough, the German Dominican friar Felix Fabri is the only one to mention it. ${ }^{117}$

As far as pilgrims' references are concerned, it is interesting to note that none of the travelogues that mention the cathedral, in a more or less detailed way, records all the aforementioned relics. The first reference to the church, made by the Irish Franciscan monk Symon Semeonis (1322-1324), is an indirect one, actually mentioning only the saint who Christianised the island. ${ }^{118}$

In 1435 Hans Lochner is the first to mention, other than the relic of St Titus, the head of St Barbara, also held and venerated in the cathedral. ${ }^{119}$ Ulrich Brunner in 1470 enriches the catalogue of the relics held in the church of St Titus: 'the head of St Titus, disciple of the Apostle Paul who brought the island to the Christian faith; the head of St Barbara, queen of Cyprus, an arm of St Stephen, an arm of St Endris and an arm of St Blaise.'120

114 About the icon of the Virgin, see Theochari 1961, 270-282; Georgopoulou 2001, 217-223.

115 The altar was reconsecrated by Archbishop Fantinus Dandolus on 4 January 1446, the feast day of St Titus. Georgopoulou 1994, 112; Georgopoulou 2001, 113; Georgopoulou 2013, 145. About the inventory of the holy relics translated from the church of St Titus to Venice in 1669, see Gallo 1967, 125-127; Gerola 1903, esp. 259-26o.

116 Georgopoulou 2001, 117; Xerouchakis 1933, 28; Tafel and Thomas 1856, 87-88. The letter of the pope, dated 27 February 1209 , does not specifically mention the church of St Titus, but Cretam in general.

117 See $n .154$ below.

118 See $n .149$ below.

119 The full text reads: 'An heiligthümern fanden sich daselbst für das Interesse der frommen Pilger die Reliquien des auf der Insel geborenen heiligen Titus, de unmittelbaren Schülers des Apostels Paulus vor, sowie das haupt der heiligen Barbara, der Schutzheiligen der Konstbler und Bombarderie.' Geisheim 1858, 8o.

120 'item zu Candia in der stat ist das haupt Titi, der do ist gewest eyn jünger sant Paülüs, und sanctus Paulüs hat die gantzenn inseln zu christenlichem glaubenn bracht. item do selbst ist das haupt sandt Barbera, der küngin von Cipern, item do selbst ist ein arm von sant Steffan un ein arm von sant Endris und ein arm von sant Blasius.' Röhricht 19o6, 23-24. 
As far as the actual building is concerned, no full descriptions of it survive in the travelogues. Generally, they simply mention the cathedral and its dedication to Crete's patron saint, as well as the relics held in it. Very few pilgrims provide details of the building. Wilhelm Tzewers in 1477 characterises the cathedral as small. ${ }^{121}$ On the other hand, Pierre Barbatre, travelling in 1480, finds it to be a 'quite beautiful church', while the Netherlandish pilgrim Johannes Cotovicus, writing in 1598, seems to agree with the French traveller, referring to the 'very beautiful ancient cathedral of St Titus'.122

It is not an uncommon phenomenon for Western pilgrims to appear disappointed by the churches they visit in the Venetian-occupied towns of Greece. The Latins usually appropriated the already existing cathedral of each town and modified it to fit their liturgical habits, usually by adding new chapels and side altars. In the case of the cathedral of Candia, however, its appropriation by the Latins seems to have been architecturally expressed quite successfully, given the fact that Western travellers do not comment on it in the way they did for the cathedrals of the other Latin-ruled ports of Corfu and Modon.

The magnificence of Candia's cathedral is articulated in a 16th-century description of its interior: '[...] a large, tall structure with innumerable columns of various styles made of rare marble; it was adorned with the tombs and coats of arms of famous noblemen and with precious altars and chapels decorated in such a way that all these were an eternal ornament to the city.123 In addition, already from the 15th century and in particular during the incumbency of Archbishop Hieronymus Landus, an elaborate organ existed in the church, as well as a school of ecclesiastical polyphonic music. ${ }^{124}$

The church of St Titus was an important public monument of Venetian Candia for Latins and Orthodox alike. The duke attended mass there, while several dukes of Crete were buried in it. Housing the relics of the town's patron saint, as well as the highly venerated Lucan icon of the Virgin, it was a focal point for both the main religious communities of Candia. Common liturgies in honour of the relic of St Titus and his effigy were held in the cathedral, while the Greeks were allowed to venerate them following their rite and liturgical habits. ${ }^{125}$ As in the case of Corfu's patron saint, St Arsenius, the Orthodox of Candia actively participated in the official veneration of St Titus. In fact, within

\footnotetext{
121 See $n .189$ below.

122 Pierre Barbatre (1480): ‘[...] asses belle eglise et honneste'. Pinzuti and Tucoo-Chala 1972-1973, 123. Johannes Cotovicus (1598): 'Neque praetereunda est pulcherrimi \& vetusti operis basilica Diuo Tito sacra.' Cotovicus 1619, 68.

123 Translation after Georgopoulou 2001, 113 and n. 16. The full text is also in Gerola 19o8, 41.

124 Kritsotaki 1995, 348; Panagiotakis 1990, 14-17, 137.

125 See pp. 194-195 below.
} 
the structure of the Venetian religious policy of retaining the fragile equilibrium between the local Orthodox population and the Latin Venetians, they were allowed to worship his relic in the church of St Titus and even, during its weekly procession, to carry it to the Orthodox cathedral, as well as other Greek churches of the town and borgo. ${ }^{126}$

The cathedral's importance for the town of Candia is also attested by the fact that in extraordinary circumstances state funds were channelled to the church: in 1320 a very significant income of the city, the toll tax (padagium porte), was given for a period of two years to the archbishop for restorations of the church. ${ }^{127}$ Thus, the cathedral of St Titus very soon after its appropriation by the Venetians became the focal centre of most of the religious and secular events of Candia. ${ }^{128}$

\subsubsection{The Relic of St Titus}

The patron saint of Candia, St Titus, was a disciple of the Apostle Paul; hence much information about him derives from Paul's epistles. ${ }^{129}$ The early sources concerning the saint do not mention his origins. It has been suggested that he was born in Corinth or Antioch, while the apostle refers to him with the general term 'Greek'.130 Titus appears for the first time as a companion of Paul and Barnabas at the Apostolic Council of Jerusalem around $49 \mathrm{AD}$ and then travelled with the apostle in Asia and Europe. The Apostle Paul refers to him as 'mine own son after the common faith' and brother, while entrusting him with the delicate task of restoring peace to the Corinthian Church. ${ }^{131}$ Around 62 or 63 St Titus followed the apostle to Crete to preach the Gospel and was left there in order to organise the Cretan Church: 'For this cause left I thee in Crete, that thou shouldest set in order the things that are wanting, and ordain elders in every city, as I had appointed thee.'132

126 Papadaki 1995, 179.

127 Georgopoulou 2001, 116; Tsirpanlis 1985, 295.

128 Laudi and hymns to the Serenissima, the patriarch and the local authorities were sung in the cathedral at Easter and Christmas and on the feast days of St Mark and St Titus. The official ceremony of the Laudi had been established by Doge Pietro Ziani with the decree of September 1211 known as the Concessio Crete. Later on, Laudi were instituted on the day of the Epiphany, All Saints' Day and 1o May, in commemoration of Venice's victory over the rebels at the 'Revolt of St Titus' in 1363. Cornelio 1755, vol. 1, 31-33, 229, 258; Xerouchakis 1933, 28; Georgopoulou 2001, 118; Papadaki 1995, 76.

129 Specifically the second epistle to the Corinthians and the epistles to Timothy, Titus and the Galatians.

130 Detorakis 1970, 20; Galatians 2:3.

131 Titus 1:4. Detorakis 1970, 20; Halkin 1961, 322; BS 1969, col. 5 O3.

132 Detorakis 1970, 21, n. 2. Titus 1:5; Detorakis 1970, 21; Halkin 1961, 322. 
At some point after the 6th century a new, enriched vita of the saint appeared and created a whole new tradition concerning him. ${ }^{133}$ According to it, Titus was a member of a prominent family of Crete and a descendent of the mythical King Minos. As a young man, he received a classical Greek education, until a voice urged him to travel to Jerusalem. Arriving in the Holy Land he became an eyewitness to the Passion and Resurrection of Christ and was converted to Christianity by the Apostle Peter. ${ }^{134}$ Titus then became a disciple of the Apostle Paul, who, as already mentioned, entrusted him with the organisation of the Cretan Church. Many miracles were attributed to the saint during his lifetime, as well as after his death at the age of $94 .{ }^{135}$

The Western tradition concerning the saint that appeared in the 9th century also followed the aforementioned 6th-century vita. He was celebrated on 4 January, natalis sancti Titi, by the Catholics, while the Orthodox celebrated the day of his death, 25 August. ${ }^{136}$ His feast day was one of the official public holidays of the town of Candia and was celebrated with pomp with a public veneration of the saint's relic, a liturgy and a procession with the participation of the town's authorities, the guilds and fraternities and representatives of both the Latin and Orthodox clergies. ${ }^{137}$ As mentioned above, the Orthodox celebrated the saint on 25 August, but, due to the fact that the vine harvest took place during this summer month, many local synods of the Latin bishops were held and repeatedly moved the saint's feast day in order to ensure maximum participation in the celebrations. Thus, St Titus was feted, according to the respective synod decision, on 4 January, 4 May, 25 August and 2 October. ${ }^{138}$ Eventually, following the proposal of Archbishop Hieronymus Landus at the synod of 1467 , the celebration of the saint's feast was set on 2 October. ${ }^{139}$

133 The anonymous author, in an attempt to attach validity to his writings, attributed it to Zena, the jurist who worked with Titus for the organisation of the Cretan Church. Detorakis 1970, 22; BS 1969, col. 504.

134 Detorakis 1970, 22; Halkin 1961, 322-323; BS 1969, col. 504.

135 Hagiographical accounts refer to miracles performed by the saint at his tomb in the cathe-

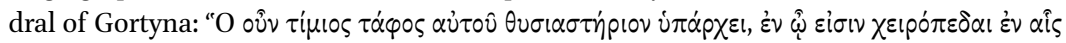

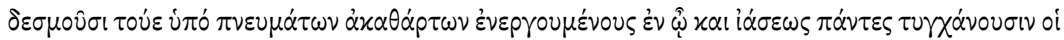

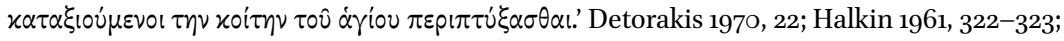
BS 1969, col. 504 .

136 Detorakis 1970, 25; BS 1969, col. 504.

137 For the celebrations that took place on St Titus's feast day, see Georgopoulou 2001, 118; Xerouchakis 1933, 28; Papadaki 1995, 21, 70-71.

138 Detorakis 1970, 26; Xerouchakis 1933, 31.

139 Archbishop Fantinus Vallaresso suggested moving the saint's feast to 4 May, while Archbishop Fantinus Dandolus suggested 4 January, the day of the commemoration of the saint's death by the Catholic Church. With an edict issued on 26 December 1519 Duke 
However, and despite the fame and veneration St Titus enjoyed in the capital city and its cathedral, his cult seems to have been localised in Candia. Besides the destroyed church at Gortyna, only one other church is known to have been dedicated to his name. ${ }^{140}$ On the other hand, the saint was depicted in frescoes in churches around the island from as early as the 11th century, indicating an established cult already from the Byzantine period. The saint, following the Byzantine iconographic patterns, is depicted as an Orthodox bishop, holding in his left hand the Gospel and blessing with his right. ${ }^{141}$ An icon of the late 16th century by the Candiot painter Georgios Clontzas depicting the saint as a Latin bishop could be used as another attestation of the fame he enjoyed among the Latins of the town. ${ }^{142}$

As mentioned above, the cult of St Titus was flourishing already from the Byzantine period and by the time the Venetians occupied Crete he was the most important figure in the local saintly hierarchy. In the 6th century a wooden-roofed basilica housing the saint's tomb was erected in the capital city of Gortyna and soon became a cultic attraction for pious Cretans throughout the first Byzantine period of Crete, until its occupation by the Arabs. ${ }^{143}$ During the second Byzantine period of the island, when the capital was moved to the town of Candia, a new church was built in honour of the saint, and his relic was transferred and venerated there. ${ }^{144}$ Thus, by the time of the Venetians' arrival, the cult of St Titus was strong and deeply rooted in the area.

After its translation to the cathedral of the new capital, St Titus's relic was placed at the central altar, where the pious could prostrate to it. Additionally, every year on the feast day of the saint it was displayed for public veneration. ${ }^{145}$

Antonio Morosini determined the feste comandate, setting the day of the commemoration of St Titus as 2 October. Xerouchakis 1933, 21; Papadaki 1995, 25, 70.

140 From a total of more than 8 oo churches of Crete published by Giuseppe Gerola, only one is dedicated to St Titus. Gerola 196o, 9o, no. 616; Detorakis 1970, 28.

141 Depictions of St Titus appear in at least four rural churches: St Euthymios, near Chromonastiri in Rethymnon, St Michael the Archangel at Kouneni, St Photini, near the monastery of Preveli, and Panagia Gouverniotissa in Potamies Pediados. See Georgopoulou 2001, 117 and n. 3 o.

142 Georgopoulou 2001, 117 and n. 37.

143 Detorakis 1970, 26; Georgopoulou 1995, 117; Georgopoulou 2013, 144-145. About the church of St Titus in Gortyna, see Di Vita 1985, 137-143, and Orlandos 1926, 301-328.

144 The reason for this partial translation of the saint's relics from Gortyna to Candia is not clear. Perhaps, as Maria Georgopoulou suggested, it was the result of a compromise between the two largest cities of the island. The actual date of the translation is also uncertain, but in 1211, when the Latin archbishop arrived in Candia, the head of St Titus was kept in the town's cathedral. Georgopoulou 2013, 144-145; Georgopoulou 1994, 111; Xanthoudides 1915, 318.

145 Georgopoulou 2001, 118; Papadaki 1995, 69-70. 
No specific information has survived about the reliquary it was kept in, but there is no doubt that it would have been elaborate. A document of 24 February 1669, listing the relics transported from Candia's cathedral to Venice after the fall of Crete to the Ottomans, mentions that the saint's head was covered with silver, while also referring to a silver reliquary. ${ }^{146}$

Most of these facts, as testified by the documents, are corroborated by some pilgrims' narratives. In 1518 Jacques Le Saige reports seeing 'the saint's head entire', while the English priest Richard Torkington, who travelled during the years 1517-1518, wrote: 'I saw the hede of the seyd Titus Coverd wt sylver and golde. ${ }^{.47}$ No other information is given by the pilgrims in regard to the saint's relic or reliquary. However, the Polish traveller Mikołaj Krzysztof Radziwiłł (1583-1584) describes the procession to the cathedral and the public veneration of the saintly relic, which was followed by a meal at the archbishop's palace. ${ }^{148}$

The first reference to St Titus's relic in pilgrims' narratives was made by the Irish Franciscan monk Symon Semeonis (1322-1324): 'They say that in this church is the body of Bishop Titus, disciple of Paul and patron saint of Crete, who is mentioned in Paul's epistles and the Acts of the Apostles. ${ }^{.49}$ The sentence he uses to describe Candia's patron saint contains all the pieces of information pilgrims had about him and, amongst them, the most important detail: his relation to the apostle. It was through this connection that St Titus was elevated from a local saint to an important holy figure. All the pilgrims who refer to St Titus's relic after the Franciscan monk's first mention more or less convey the same information. The saint's personal experience of the Passion and his relationship to Paul, attested in the apostle's epistles, are underlined in the travelogues, since they connect the relic venerated in the cathedral of Candia to Jerusalem, allowing the evocation of the Holy Land. ${ }^{150}$

In broad lines, the pilgrims seem to have been well informed about St Titus. All of them mention that he was a disciple of the Apostle Paul, while most of them add that he was appointed bishop of Crete by him and that he is mentioned in the apostle's epistles. The fact that the saint's tomb was originally in the first Byzantine capital of the island, the town of Gortyna, is also mentioned

\footnotetext{
146 The inventory was published by Rodolfo Gallo, in Gallo 1967, pp 125-127.

147 ' $[. .$.$] le chief tout entier'. Duthill 1851, 83. Loftie 1884, 2$ O.

148 'Inde itum est, cum Processione ad summum templum S.Titi; cuius venerandum caput integrum, magna ceremonia, spectandum populo proponebatur. Sumpto prandio salutaui Archiepiscopum.' Treter 1614, 20.

149 'In ipsa dicitur esse corpus beati Titi episcopi, Pauli discipuli et Cretensium patroni, de quo in Epistolis Pauli et Actibus Apostolorum mentio sepe habetur.' Esposito 196o, 42.

$15^{\circ}$ About the stragegies employed for the evocation of the Holy Land, see Bacci 2017 a.
} 
in the travelogues. Richard Torkington, the Englishman who described the saint's gilt head, actually visited Gortyna and attested that: 'In that londe, $\mathrm{xxx}$ myle from Candy, ys an old brokyn Citee whiche was callyd Cretina, And a lityll ther be syd stondyth an old Churche which was byldyd in the honour of Jhu Criste And holowyd in the worshipe of Titus Epiis, to whome Seynt Poule wrott in Actibus Aptor ad Titum. ${ }^{151}$ In 1598 Johannes Cotovicus visited the cathedral of Candia and wrote about its most venerated saint: 'In it the body of St Titus, disciple of the Apostle Paul [...] is honourably kept under the main altar; and it is highly venerated by both Latins and Greeks.' ${ }^{152}$

In 1531 the French pilgrim Nicolas Loupvent provided even more information, linking the Cretan relic to the relic of Titus's sister, the virgin St Euphemia, kept and venerated in Rovinj, Croatia: '[...] The cathedral of the town is erected and constructed in the honour of St Titus, who was one of the 72 disciples of our Lord, brother of St Euphemia (whose body is at Rubigne [Rovinj] and we have already written about it) and disciple of the Apostle Paul, who often wrote epistles "ad tytum".'153

Oddly enough, the fact that the cathedral and the relics held in it were attributed indulgences already from 1209 does not seem to be known to the pilgrims. At least this is not mentioned by any of them, except the Dominican friar Felix Fabri (1480, 1483-1484). He mentions visiting the church of St Titus '[...] for the indulgences, as well as to see the holy relics: because this is what the pilgrims do in every place they visit; first and foremost [they] run into the churches for the indulgences.' ${ }^{154}$

Besides the obvious similarities to the cases of Corfu and Modon, Candia's patron saint presents a special, idiosyncratic case: the highly venerated saint

151 Loftie 1884, 2 O.

$15^{2}$ 'In hac corpus Diui Titi, Pauli discipuli (qui primus in vrbe Gortyna, Cretae quondam regia, ab eodem constitutus Episcopus, Cretensem Ecclesiam rexit) sub arâ maxima conditum, honorifice asseruatur; estque in summâ apud omnes, \& Latinos \& Graecos, veneratione.' Cotovicus 1619, 68.

153 ' [...] la cité métropolitainne et archiespiscopale est dict Candia. La grande esglise dicelle, érigée et construict en lhonneur de monseigneur sainct Tite, qui fust lung des LXXII disciples de Notre Seigneur, frère a madame saincte Eufemie (de laquelle corps gist a Rubigne, que nous avons devant dict), et disciple de monseigneur sainct Paule, auquel souventefoys escripvoit ses Espitres "ad tytum".' When visiting Rovigno (Rovinj) and St Euphemia's relic, Nicolas Loupvent also makes a reference to Candia and St Titus: '[...] on nous monstraict entièrement le corps de Madame saincte Eufèmie, vierge et martir, seure germaine a monseigneur sainct Tite, disciple de sainct Pol et patron de la grande esglise de Candie.' Bonnin 1976, 55, 37 .

154 ' $[. .$.$] ingressi sumus ecclesiam S. Titi pro indulgentiis et ad videndum reliquias Sanctorum:$ sic enim in omni loco peregrini faciunt, quod primo et ultimo in ecclesias currunt pro indulgentiis.' Hassler 1843-1849, vol. 3, 287. 
of Candia was known to Westerners already from the gth century, while in 1209 Pope Innocent III promised the pilgrims who prostrated to his relic the same indulgences as the crusaders who went to Jerusalem, thus elevating the position of the saint within the hierarchy of the Latin church. ${ }^{155}$ In addition, as Maria Georgopoulou aptly pointed out, St Titus's personal experience of the Passion of Christ and his special ties to Crete, as well as his Early Christian origin and the civic connotations of the continuing Byzantine tradition of his cult, made him a perfect symbol for the newly established Latin Church of Crete. ${ }^{156}$ Especially after the particularly adroit handling of the 'Revolt of St Titus' in 1363, when the saint was used by both the rebels and the authorities as the divine protecting and leading figure, the Venetians elicited the saint's support in governing the island. ${ }^{157}$ The Lauds service during the civic celebrations in Candia, after evoking Christ and praising God, the doge and the wise government of Venice, pleaded for the saint's help: Sancte Tite tu nos adjuva. ${ }^{158}$ St Titus's relic became an integral part of the Venetian heritage of Crete and, following the island's occupation by the Ottomans in 1669, it was transferred to Venice. The relic of Crete's patron saint was kept at the basilica of San Marco and was displayed for veneration on the church's high altar every year on his feast day on 4January, until it was returned to the church of St Titus in Heraklion in May 1966 (Fig. 70).159

Overall, St Titus is the undeniable protagonist in the pilgrims' narratives when it comes to Candia. During the period from the 14th to the 16th centuries, he is referred to almost as many times as St Leo of Modon and the monastery of the Virgin of Strophades. However, the number of mentions to the patron saint of Candia remains less than half than the ones to the church of the Virgin in Kassiopi.

155 Detorakis 1970, 25; BS 1969, col. 504. About the indulgences, see Georgopoulou 2001, 117; Xerouchakis 1933, 28; Tafel and Thomas 1856, 87-88.

156 Georgopoulou 2001, 116.

157 In 1363, because of the excessive taxation imposed by the Serenissima, the Venetian feudal lords of Crete allied with the local Byzantines and rose up against the Venetian government. Their banner declared the 'Republic of St Titus', highlighting the symbolic power of the cult on the inhabitants of the island. After the suppression of the revolt, the Venetian authorities instituted an annual procession starting from the church of St Titus, as well as a horse race (palium) on 10 May. Georgopoulou 2001, 119; Georgopoulou 2013, 145. About the rebellion, see McKee 1995, 173-204; Xerouchakis 1932. About the celebrations held for the commemoration of the suppression of the rebellion, see Papadaki 1995, 163-168, 171-174.

158 Georgopoulou 2001, 118; Xerouchakis 1933, 28.

159 Olivotti 1966. 


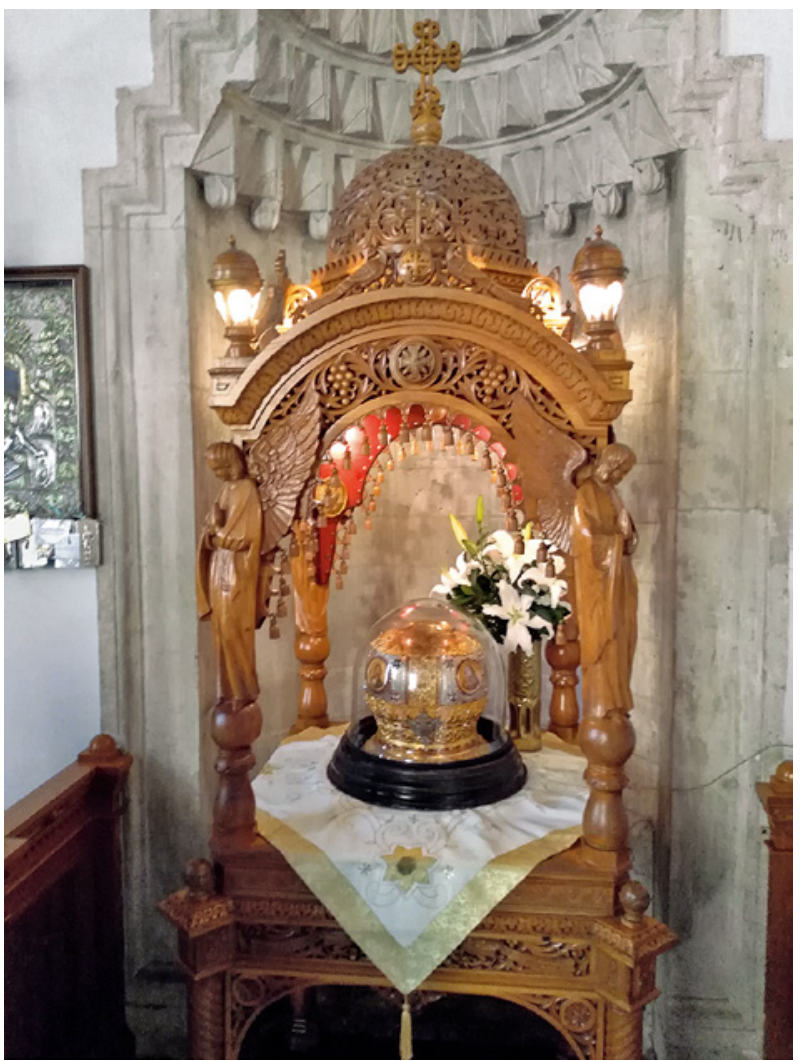

FIGURE 70 The head of St Titus in the church of St Titus, Heraklion

\subsubsection{The Icon of the Virgin Mesopanditissa}

The icon of the Virgin, known as 'Mesopanditissa' or the 'Madonna of St Titus', was the most venerated holy object in Candia. The Byzantine icon, reportedly a portrait of the Virgin by the Evangelist Luke, depicts the Virgin of the Hodegetria type, flanked by two angels. Due to extensive overpainting, its date cannot be established based on a stylistic analysis. It is believed to have been a product of a Byzantine workshop of the 12th or 13th century (Fig. 71). ${ }^{160}$

The palladium of Candia was housed and venerated in the cathedral of the town already from the Byzantine period. In fact, its cult was so strong that it was almost immediately incorporated by the Venetians after the occupation of Candia and soon became the centrepiece of religious ceremonies. As in the case of the holy relic of the town's patron saint, the Venetian authorities

16o Gerola 19o8, 302; Theochari 1961, 271, 275; Georgopoulou 2001, 217. 


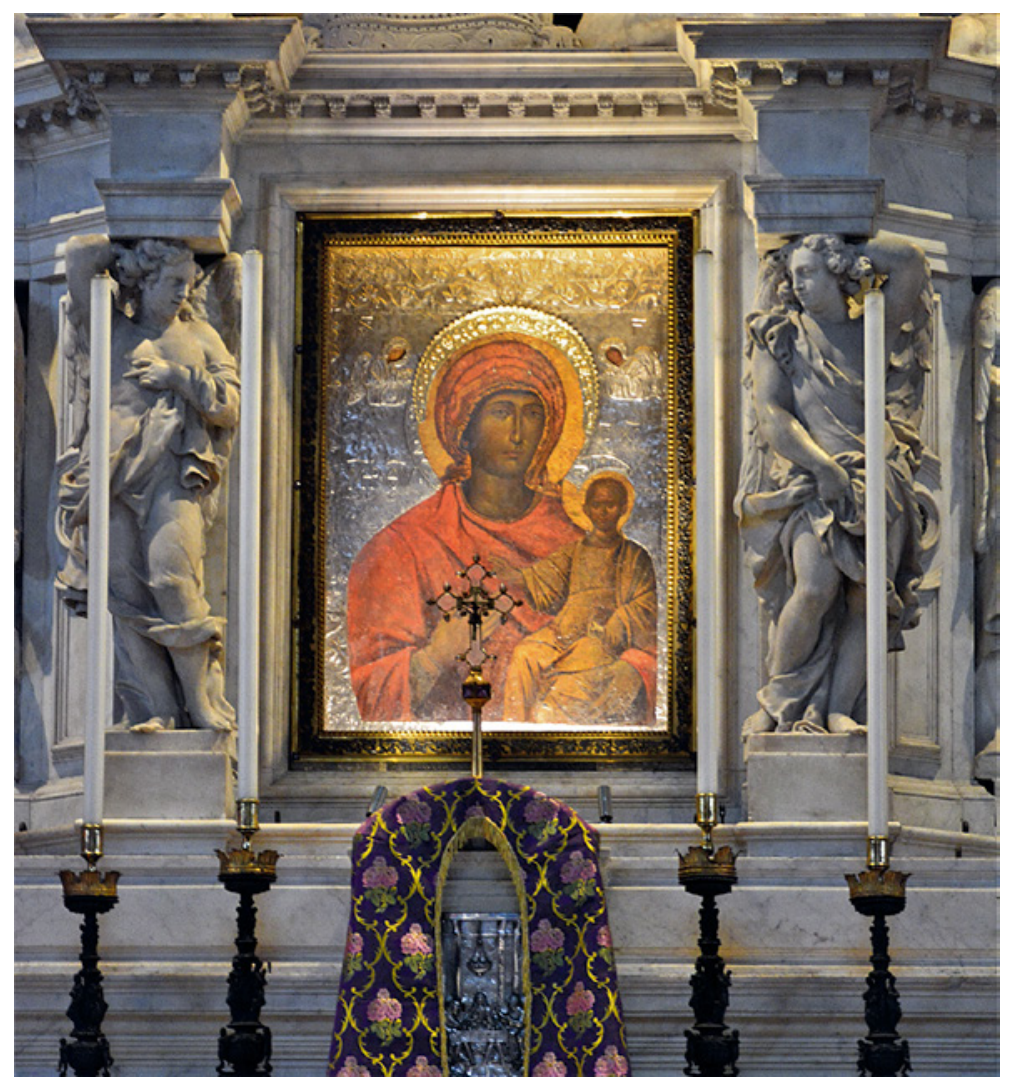

FIGURE 71 The icon of the Virgin Mesopanditissa in Santa Maria della Salute, Venice

evoked the Virgin Mesopanditissa's support in governing the island. So, this icon also became an integral part of the colonial heritage of the Venetians and was shipped to Venice when the island fell to the Ottomans. The 'beautiful miraculous Virgin of St Titus', as mentioned in an inventory of 1669, was placed after its arrival in Venice on the high altar of the church of Santa Maria della Salute, where it remains until today (Fig. 72 ). ${ }^{161}$

The legend concerning Candia's most venerated icon follows a common topos in regard to miraculous icons, employed to enhance its antiquity and sacredness, that is, its Constantinopolitan origin and its transfer to Crete

161 'Beatissima Vergine miracolosa di San Tito'. Gerola 1908, 302; Gerola 1903, 246; Theochari 1961, 271; Georgopoulou 2001, 223; Papadaki 1995, 187. 


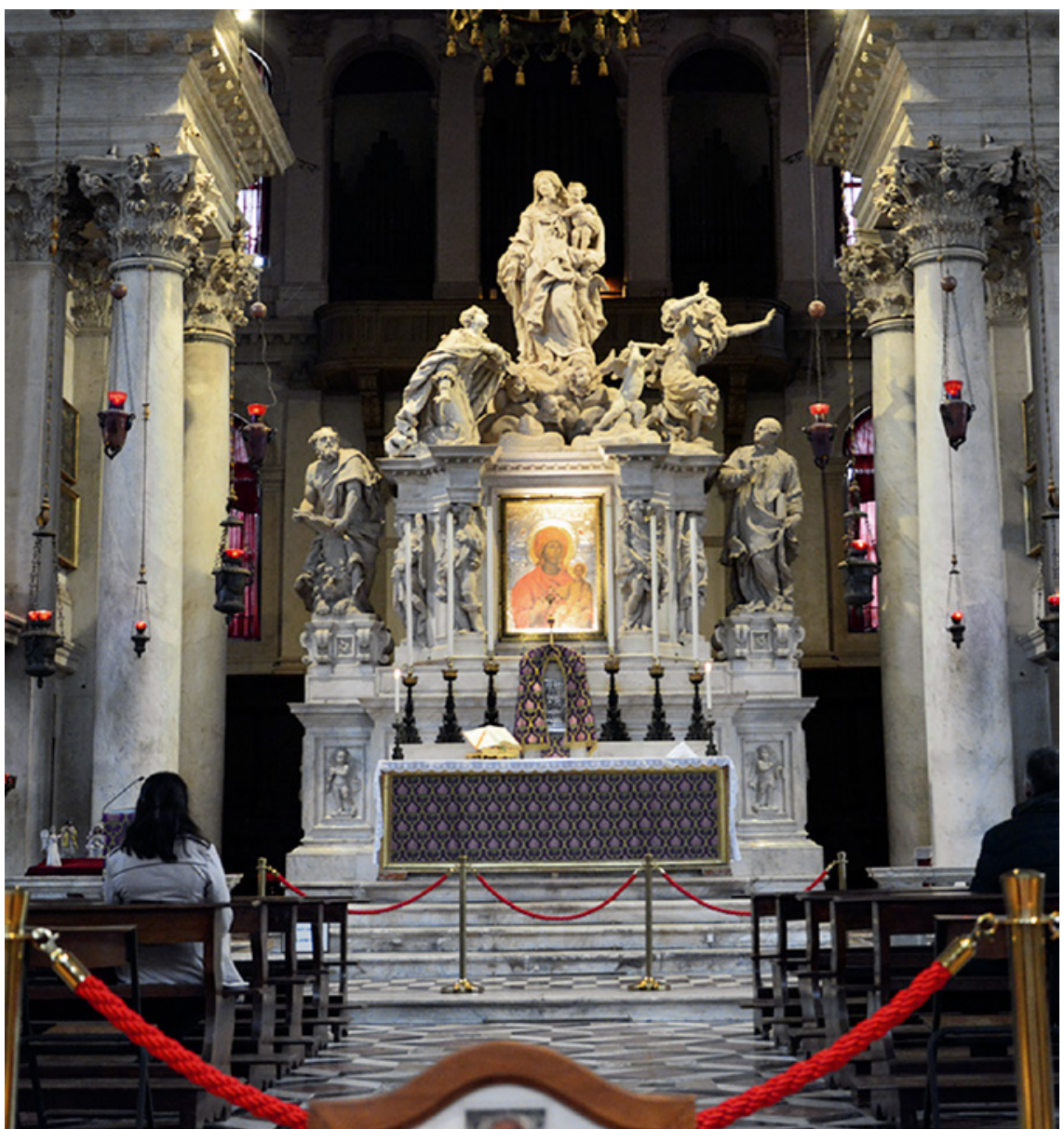

FIGURE 72 The altar and the icon of the Virgin Mesopanditissa in Santa Maria della Salute, Venice

during iconoclasm. ${ }^{162}$ However, the most interesting tradition related to it, which underlines its power and, most importantly, inextricably links it to the Venetians, legalising and justifying their authority on the island, is the one concerning its miraculous intervention that brought peace between the Venetian rulers and the Greek rebels in 1264. According to the account of the former vicar of Candia's cathedral, Angelo Venier, after a revolt in 1264 and following the submission of the Greeks, the latter, to ratify the peace, offered the icon to the island's new overlords. As attested by the chronicler Antonio Trivan,

162 Theochari 1961, 271, 275. 
the treaty between the Greeks and the Venetians was signed in front of the icon of the Virgin, which was afterwards carried in a procession around the town, followed by Greeks and Latins, laymen and members of the clergy. ${ }^{163}$ According to the same tradition, it was then that the icon was attributed the epithet 'Mesopanditissa', translated in Venetian sources as mediatrice, mediator of peace. ${ }^{164}$

As mentioned above, the icon resided in the town's cathedral. Although its exact location in the church is unknown, it would be plausible to assume that Candia's most venerated, miracle-working icon was placed in an elaborate central chapel. A testament of 15 o1 refers to the altar of 'our lady Mesopanditissa which is inside the church of St Titus.' ${ }^{165}$ It was there that, according to the tradition, the icon performed miracles. Surviving testimonies of the 16th century describe two miraculous healing interventions of the Virgin: in 1575 and in 1599 respectively, it enabled a 40-year-old woman and a Milanese soldier to walk again. ${ }^{166}$ The chapel of the icon was decorated among other things with paintings. As attested in a document of 5 May 1573, the bishop of Siteia and Ierapetra commissioned two large paintings, one of the Nativity and one of the Coronation of the Virgin to adorn it. ${ }^{167}$ The popularity of the icon among both Latins and Orthodox was reflected as well in the donations and ex-votos of the pious; it is known that in later centuries it was covered with a silver revetment and precious offerings. The icon's veneration followed Late Medieval practices: the pious would prostrate before it and make offerings of candles, donations and ex-votos, while a surviving description of the adoration of the icon by the Greeks provides very interesting details: 'There was always a group of Orientals who repeated the scenes in the Temple of Jerusalem and who,

163 Theochari 1961, 274, n. 13; Georgopoulou 2001, 218, n. 23.

164 The translation of the epithet 'Mesopanditissa' as mediator appears in the Venetian sources. However, Maria Theochari, who has studied the icon, does not accept this interpretation. Instead, she argues that the epithet refers to the location of the icon in the church, since in the Cretan dialect the adjective $\mu \varepsilon \sigma o \pi \alpha v i$ itns (mesopanditis) refers to the one living in the interior areas. Theochari 1961, 273; Georgopoulou 2001, 218; Papadaki 1995, 177; Xerouchakis 1933, 29. About the interpretation of the epithet 'Mesopanditissa', see Theochari 1961, 274-275.

165 '[... altar de la nostra domina Mesopanditissa che est dentro la gexia de misser San Tito'. Georgopoulou 2001, 218, n. 22.

166 The miracles are described in two ducal letters to the doge, dated 26 October 1575 and 27 April 1599. The second miracle is also attested by the Archbishop of Crete, Tomaso Contarini. Both of the miracles were celebrated by a litany of the icon. Papadaki 1995, 185 .

167 The paintings were the work of the Greek artist Markos Chalkiopoulos. Panagiotakis 1986,24, n. 2. 
during the big feast days, were not afraid to bring their beds to the altar of the Virgin Mary.'168

However, the ultimate attestation of the icon's importance to the city of Candia and its rulers and inhabitants alike is the fact that it was carried in a procession every Tuesday. The weekly procession of the Mesopanditissa icon was one of the most important ceremonies of Venetian-ruled Candia. ${ }^{169}$ The icon was also carried in procession during the celebration of Corpus Christi, while impromptu processions were carried out for such emergencies as earthquakes, famine, poor weather conditions and so on.

The fame and popularity the icon enjoyed in Candia both from Latins and Orthodox is not reflected by any means in the pilgrims' travelogues. Actually, there are no direct mentions to the Madonna of St Titus. Throughout the time frame of this study, two pilgrims refer to an icon of the Virgin painted by St Luke, which could thus be identified as the Virgin Mesopanditissa, but neither of them specifies its exact whereabouts. ${ }^{170}$ It is also known that the Franciscans of Candia kept an icon of the Virgin attributed to the hand of the Evangelist in their conventual church, thus it cannot be determined to which icon each of the pilgrims was referring. ${ }^{171}$

If one accepts that the two pilgrims were referring to the Madonna of St Titus, those are the only mentions of the icon in the travelogues from the 14th to the 16th centuries. In the 17th century, however, two pilgrims, Wolfgang Stockman and Johannes Habermacher, clearly refer to the miraculous icon of the cathedral. ${ }^{172}$ In particular, Stockman, who visited Candia in 1606, conveys important information about its cult and veneration in Venetian Candia. The Swiss traveller describes a procession of the icon from the cathedral to the Augustinian monastery, where another icon of the Virgin, originating from Rhodes, was kept. Additionally, he also attests to a miracle performed by the icon: after the supplication of the priests and the pious, it brought rain to the city. ${ }^{173}$ Stockman's quite detailed description is indicative of the high rever-

\footnotetext{
168 Georgopoulou 2001, 223, n. 42.

169 Georgopoulou 2001, 221; Papadaki 1995, 179.

170 Jan Aerts (1481) and Hans Schürpff (1498). Nispen 1652, 152; Schmid 1957a, 8.

171 It should be noted that, as attested by only one pilgrim, the miraculous icon of the church of the Madonnina was also attributed to Luke. See n. 90 above.

172 While Wolfgang Stockman clearly refers to a miraculous icon of the Virgin kept in the cathedral and another icon originating from Rhodes, Johannes Habermacher seems to confuse the two images, identifying the icon kept in the church of St Titus as the Rhodian one. Schmid 1957c, 340-341; Schmid 1957b, 176-177.

173 Schmid 1957c, 340-341.
} 
ence in which the icon was held by the inhabitants of Crete, both Latins and Greeks, and the way it was conveyed to a foreign visitor. The 'effectiveness' of the effigy is also eloquently expressed.

Apart from the documents and the travelogues that refer to the Madonna of St Titus, an interesting insight into its importance to the locals is also provided by the writings of a Cretan refugee in Venice. In his work L'Occio, Zuanne Papadopoli, a citizen of Candia who fled to Venice after its occupation by the Ottomans, describes his beloved town in detail. When writing about the town's Latin cathedral and although he dedicates quite a few paragraphs to it, Papadopoli makes no reference to any of the other relics kept in the church except for the icon and the phial containing the blood of Christ. ${ }^{174}$ In fact, more than half of the description of the cathedral concerns the miraculous icon, its holiness and its intervention to bring peace to the town of Candia, where the Greek writer repeats the tradition of the attribution of the epithet 'Mesopanditissa', its weekly procession and its transfer to the church of Santa Maria della Salute in Venice. ${ }^{175}$ This fact is indicative of the significance of the icon for the Greeks, since, aside from the cathedral's other relics, it seems to overshadow even the venerated relic of the town's patron saint, St Titus.

Summing up, as in the case of Candia's patron saint, the cult of the icon of the Virgin Mesopanditissa was very soon appropriated by the Venetians. The Byzantine icon, besides becoming Candia's most venerated cult object, placed the city in the network of Marian cult sites that dotted the sea route to the Holy Land. ${ }^{176}$ In addition, it was used by Candia's new rulers as a sanctifying agent of their governance. It remained in the cathedral, where the Orthodox were allowed to worship it following their own traditions, while during its weekly procession it was carried to the Orthodox cathedral, as well as other Greek churches. ${ }^{177}$ Similar to the relic of St Titus, the Lucan icon was employed as a unifying actor for Latins and Greeks, highly venerated by both in common elaborate religious ceremonies. ${ }^{178}$

\footnotetext{
174 Deligiannaki 2017, 66-68.

175 Deligiannaki 2017, 66-68.

${ }_{17}$ About the Marian cult sites along the route to Jerusalem, see Bacci et al. 2017. About the Marian pilgrimage in Greece, see Moira and Mylonopoulos 2017.

177 Papadaki 1995, 179.

178 An analogous phenomenon on a much smaller scale can be seen in the town of Corfu in regard to the venerated icon of the Virgin Demosiana. There are also obvious similarities with the Venetian handling of the popularity of local saints, such as St Arsenius and St Spyridon on Corfu and St Leo in Modon.
} 


\subsubsection{Other Relics}

Overshadowed by the relics of St Titus and the icon of theVirgin Mesopanditissa, a collection of several other holy relics was housed in the cathedral of Candia: among others, the head of St Barbara, the arms of St Ephraim and St Stephen, the relics of St Martin and St Lucy, the tibia of St Sabbas and a reliquary containing the blood of Christ. ${ }^{179}$

The relics of St Stephen, St Martin and St Lucy, along with the relic of St Titus, were placed at the new altar erected above the tomb of Archbishop Fantinus Vallaresso and were reconsecrated by Archbishop Fantinus Dandolus in $1446 .{ }^{180}$ From this collection of other relics, translated to Venice in 1669 along with the rest of the possessions of the cathedral, only the arm of St Stephen is mentioned in the pilgrims' travelogues, by the German Ulrich Brunner in $1470 .{ }^{181}$

It has been suggested that the relic of St Stephen was translated to Crete from Constantinople after the reoccupation of the island by the Emperor Nikephoros Phokas in the 1oth century. ${ }^{182}$ The reliquary is today lost, but based on a 1627 transcription of the verses decorating its sides, Vitalien Laurent supported that it was commissioned by Vasileios Lekapenos, while Enrica Follieri identified its shape as similar to 1oth-century Byzantine staurotheques. ${ }^{183}$

As far as the rest of the relics of the church of St Titus are concerned, it is the head of St Barbara that has a constant presence in the travelogues. Its first mention dates back to 1435 , from the German Hans Lochner. ${ }^{184}$

The relics of St Barbara, which were exhibited for adoration along the way from Venice to the Holy Land, formed a special route of holy sites leading to the saint's tomb in old Cairo. In anticipation of their visit to her burial place, pilgrims could see and venerate her arm in Venice, her head in Candia and a column in Beirut, the purple veins of which were believed to have been created by the blood that ran from her at the time of her decapitation. ${ }^{185}$ The martyr's head was covered with silver, while it bore a gilt bronze crown. ${ }^{186}$ The relic was carried in a procession in which both clergies participated, on 4 December, the

179 Georgopoulou 2001, 113. About the inventory of the holy relics translated from the church of St Titus to Venice in 1669, see Gallo 1967, 125-127; Gerola 1903, esp. 259-26o.

180 Georgopoulou 1994, 112; Georgopoulou 2001, 112; Georgopoulou 2013, 145; Gallo 1967, 125127; Gerola 19o3, esp. 259-26o.

181 See n. 120 above.

182 Georgopoulou 2001, 113, n. 12; Follieri 1964, 455-464.

183 Follieri 1964, 455-464.

184 See $n .119$ above.

185 Bacci 2017a, 138, n. 43.

186 After its translation to Venice, the head of St Barbara was given to the cathedral of Santa Maria Formiosa. Gerola 1903, 12; Georgopoulou 2001, 113, n. 14; Gallo 1967, 125-127. 
day of the commemoration of the saint. The presence of the Orthodox clergy was mandatory during the celebrations. According to the custom, the Greek priests would arrive at the cathedral on the morning of the saint's feast to follow the litany and pay the amount of one grosi to the church's archdeacon. ${ }^{187}$

As mentioned above, the relic of St Barbara was the only relic of Candia's cathedral other than the head of St Titus that was repeatedly referred to in the travelogues. Since its first mention in 1435 , it has a constant presence in pilgrims' narratives. However, not all of the travellers appear willing to accept the identification of the saintly relic they see in Candia with the Egyptian saint. The thoughts of the German Dominican friar Felix Fabri on this subject articulate these doubts:

In the said church is the head of St Titus the Apostle, disciple of Paul and archbishop of Crete; and the arm of St Ephraim, an ancient Greek doctor; and the head of the virgin St Barbara. I believe that there were many more virgins named Barbara, as I saw many heads which were said to be of the virgin St Barbara. ${ }^{188}$

Wilhelm Tzewers (1477-1478) is the only pilgrim to refer to the one Christological relic kept in the Latin cathedral of Candia, a phial containing the blood of Christ. ${ }^{189}$ Christological relics, reminders of Christ's passage on earth, were considered precious and were highly venerated. In Candia's cathedral the blood of Christ was kept in a crystal ampulla placed in a tabernacle, also of crystal. ${ }^{190}$ During the celebrations for Good Friday and after the end of the Orthodox litany, the archbishop blessed the crowd that was gathered outside the cathedral with this reliquary, which he next carried into the church, where he placed it on a special altar and then blessed, one by one, all the state officials with it. The vicar, or another canon of St Titus, continued blessing the pious who gathered for this reason at the cathedral. This procedure usually

187 As in the case of other common litanies in Candia, the Orthodox were unwilling to participate in the procession of the relics of St Barbara and were threatened with the punishment of a fine in the event that they were absent from the celebrations. Papadaki 1995, 34.

188 'In illa ecclesia est caput S. Titi apostoli, Pauli discipuli et archiepiscopi Cretensis; et brachium S. Effrem, antiqui doctoris Graecorum; et caput S. Barbarae virginis. Credo plures virgines fuisse hujus nominis Barbara, quia plura vidi capita, quae dicuntur S. Barbarae virginis.' Hassler 1843-1849, vol. 3, 287.

189 'In civitate Candia est archiepiscopatus. Ecclesia katedralis parva. Sanctus Titus patronus est insule, cuius caput habui in manibus et brachium sancti Effraim et cuiusdam beate Barbare. Est ibi sanguis miraculosus.' Hartmann 2004, 104.

19 o Georgopoulou 2001, 113, n. 13. 
lasted until midnight. ${ }^{191}$ After the island's occupation by the Ottomans, the crystal ampulla with the blood of Christ was transferred to Venice along with the other relics of the cathedral of St Titus and was placed in the basilica of San Marco. ${ }^{192}$

\subsubsection{Liturgical Habits}

The patron saint of Candia and of the cathedral bearing his name was, as expected, the focus of many religious as well as civic celebrations. Laudi and hymns to the Serenissima, the patriarch and the local authorities were sung in the cathedral at Easter and Christmas and on the feast days of St Mark and St Titus. ${ }^{193}$ Later on, laudi were instituted on Epiphany and All Saints' Day and on 10 May in commemoration of Venice's victory over the rebels at the 'Revolt of St Titus' of ${ }^{1363 .}{ }^{194}$ Grand liturgies were held and processions started and/or ended at the saint's church on Christmas, Good Friday, Epiphany and 1o May and during the celebration of Corpus Christi. ${ }^{195}$

Among these ceremonies, the majority of which was performed on the most important Christian religious holidays, two of them were directly linked and dedicated to Crete's patron saint: the celebration of St Titus's feast day and the commemoration of the suppression of the revolt of 1363 . The latter, instituted by Duke Pietro Morosini, was celebrated annually on 1o May with a litany and a horse race (palium). ${ }^{196}$ On the morning of 10 May, a grand litany started from the cathedral with the participation of both the Latin and the Orthodox clergies, similar to the litany performed in Venice on 15 June, the day of St Vito, in commemoration of the suppression of the revolt of Querini and Tiepolo. ${ }^{197}$ The horse race took place in the afternoon.

St Titus's feast day was one of the most important public holidays of Venetian Crete, celebrated every year with grandiosity and a procession with the participation of both clergies. ${ }^{198}$ Established during the Byzantine period, the

\footnotetext{
191 About the Good Friday celebrations, see Papadaki 1995, 123-126, esp. 125.

192 Gallo $1967,125$.

193 See $n .128$ above.

194 Cornelio 1755, vol. 1, 31-33; Papadaki 1995, 76.

195 Papadaki 1995, 94, 124-126, 129, 135, 163. The celebration of Good Friday, when the Latin and Orthodox clergy, along with the state officials, participated in a common celebration following a complex ritual, is of special interest, as it is indicative of the peculiarities of a religious ritual based on the coexistence of the Latins and the Orthodox, as well as the way the saint was used as a sanctifying power of the Venetian authorities and at the same time as a unifying actor of the members of the two rites. See Papadaki 1995, 124-125, 201.

196 Papadaki 1995, 163, nn. 6-7.

197 Papadaki 1995, 164, n. 9.

198 Georgopoulou 2001, 486; Papadaki 1995, 70-71.
} 
celebration of St Titus's day not only survived the Venetian occupation of Candia, but travelled along with the saint's relic all the way to Venice. After the fall of Candia to the Ottomans and the translation of St Titus's relic to the basilica of San Marco in Venice, documents attest that every year on 4 January the relic was placed on the high altar for public veneration, following the established ritual. ${ }^{199}$ Attesting to the Byzantine origins of the celebration of the saint, a document of 1248 reports that during the Byzantine period, on the day of the commemoration of St Titus, the Orthodox patriarch invited the duke and his entourage to the metropolitan palace, a custom that also survived the Venetian occupation, as attested in the 16th-century Cerimoniale. ${ }^{200}$

On the eve of the day of the commemoration of the saint, the Venetian authorities, along with representatives of both the Latin and the Orthodox clergy, gathered at the cathedral, where, during the vespers, laudi were sung to the pope and the archbishop of Candia. The same ritual was repeated on the morning of the day of the feast. ${ }^{201}$ On the morning of 2 October the Venetian officials arrived at the ducal palace, followed by the Orthodox clergy, to accompany the duke to the church of St Mark, where laudi were sung to the doge and the duke. They were sung in Latin by the Latin clergy and in Greek by the Orthodox. After this ritual, the procession headed to the cathedral, where the laudi were repeated and a liturgy was held. After the end of the liturgy the archbishop, following the Byzantine tradition, was obliged to invite the officials, as well as the Orthodox priests, to his palace. ${ }^{202}$

The grandness with which the island's patron saint was celebrated and, more importantly, the rite of the celebration, that is, the participation of the authorities and both the Latin and Orthodox clergies, as well as the laudi sung in both the churches of St Mark and of St Titus, underlines the symbolic power of St Titus. After the appropriation of his cult by the Venetians, St Titus became the sanctifying actor of the Venetian government and at the same time a unifying intermediary between the two Christian rites.

As already mentioned, even more than the relic of their patron saint the Candiots celebrated their Madonna, the miraculous Lucan icon of the Virgin Mesopanditissa. The icon was carried in a procession every Tuesday, as well as on major feast days, such as the celebration of Corpus Christi, special Sunday

\footnotetext{
199 Georgopoulou 20o1, 118, Corner 1758, 196; Cornelio 1755, vol. 1, 195; Detorakis 1970, 25; BS 1969, col. 504 .

200 Papadaki 1995, 21, 205; Tsirpanlis 1985, 43, 189.

201 First the laudo for the pope was sung, during which the archbishop stood with his head uncovered holding a candle, while, during the laudo for the archbishop, he had his head covered, and the candle was in the hands of the archdeacon. Papadaki 1995, 71.

202 Papadaki 1995, 73.
} 
litanies in preparation for the feast of the Assumption of the Virgin in August and, of course, in impromptu processions as necessary in case of earthquakes, famine, bad weather and so on. ${ }^{203} \mathrm{~A}$ litany from the cathedral to the Franciscan monastery to plead for rain was witnessed and described in 1606 by the Swiss traveller Wolfgang Stockman. ${ }^{204}$ An analogous case of a spontaneous procession right after an earthquake, in which the Mesopanditissa icon was most probably carried, was described by the Italian pilgrim Pietro Casola in 1494:

[...] I happened to see the beginning of the procession made in consequence of the earthquake. It was a very pitiful thing to see and hear. For in front of the great company of Greek boys without any order, who cried with a loud voice 'Kyrie Elieson', and nothing else, those Greeks carried in the said procession many very large figures, painted on wood. There were crucifixes and figures of Our Lady and other saints. ${ }^{205}$

Still, one of the most important ceremonies of Venetian-ruled Candia until the arrival of the Ottomans remained the weekly procession of the Mesopanditissa icon. The litany started from the cathedral of St Titus and moved on to the church of St Mark, where laudi were sung to the Republic. Afterwards, the icon was carried to the Orthodox cathedral, as well as to various Greek churches, where mass was celebrated in honour of private individuals and donations were collected. ${ }^{206}$ The procession was followed by many people, including women, who were often barefoot to fulfil a vow to the Virgin. ${ }^{207}$ Upon the icon's return to the Latin cathedral, laudi were sung for the archbishop. ${ }^{208}$ According to the chronicle of Antonio Trivan, the weekly procession of the

203 Georgopoulou 2001, 222; Papadaki 1995, 147, 177-183.

204 See p. 190 above.

205 The text reads: 'El mercore a II de iulio, smontai de galea per andare a vedere questa cità de Candia et me incontrai a vedere el principio de la processione inducta a fare per questo terremoto; era molta compassionevole cosa de vedere e de odire. Nam inante la grande brigata de fanciuli greci, sine ordine, chi cridaveno ad alta voce: "Kyrie eleyson" e nessuna altra parola; portaveno, in dicta processione, essi greci de molte figure depente sopra tavole assai grande, de crucifixi, de Nostra Dona e de altri santi.' Paoletti 2001, 15 o. The translation is after Newett 1907, 199-200.

206 The donations to the miraculous icon were collected by the protopapas and were distributed to the people involved in the litany and the canons of St Titus. Needless to say, the amount gathered from these offerings was substantial, and several times the sharing led to conflicts. Papadaki 1995, 182.

207 Georgopoulou 2001, 220-221; Papadaki 1995, 181.

208 Georgopoulou 2001, 221; Papadaki 1995, 179. 
icon was established after the initial procession upon the signing of the treaty in 1264 , thus providing a terminus post quem. ${ }^{209}$ By 1368 the icon was carried by eight people, both Latins and Greeks of high status; for their service to the community, they were exempted from guard duty (vaita) in the borgo, as well as from corvée labour. ${ }^{210}$ As already mentioned, in the weekly litany of the icon representatives of both the Latin and Orthodox rites participated. In fact, the participation of the Greek protopapas, as well as other Orthodox priests, was mandatory. ${ }^{211}$ While the Venetians treated this common celebration as a means of satisfying the devotion of the Christians of both rites, the fact that the litany included acclamation to the duke and the Venetian government, as well as acceptance of papal authority, was not appreciated by the Greeks. Hence, the Orthodox clergy was often unwilling to participate, and already by 1515 the priests of both rites faced a fine of four hyperpera if they refused to take part in the Tuesday procession..$^{212}$

Similar to most of the Venetian colonies in Greek territory, the appropriation of an already existing cult by the new rulers was carried out in the case of the Madonna of St Titus as well. The meaning of the Byzantine symbol was modified by altering the recipients of the sacred grace of the icon, which served throughout the Venetian period of the island as a sanctifying actor of the Venetian government and a mediator between Latins and Greeks on both a political as well as a religious level. After all, according to the official Venetian ideology, it was thanks to the miraculous intervention of the Byzantine icon of the Virgin Mesopanditissa that the coexistence of Latins and Greeks on Crete was achieved. St Titus's relic and the revered icon soon gained an especially high position in the saintly hierarchy of Venetian Crete. As pointed out by Maria Georgopoulou, the official standard of the last Venetian governor of Crete, Francesco Morosini, portrayed the Virgin Mesopanditissa above the lion of Venice, which is placed on the same level as St Titus, epitomising the sacred ties that the Venetians had established with the island's Byzantine tradition and demonstrating the Republic's adoption of the Cretan relics. ${ }^{213}$

209 Theochari 1961, 274, n. 13; Georgopoulou 2001, 218, n. 23.

210 Corvée, or angaria, was unpaid labour, imposed on the colonised population. By the 16th century the bearers of the icon were elected by the duke for life. The position became almost hereditary, as attested by the fact that from 1539 on they were chosen solely from among the inhabitants of the village of Ambrousa. Georgopoulou 2001, 218.

211 Georgopoulou 2001, 221; Papadaki 1995, 180.

212 Georgopoulou 2001, 221; Papadaki 1995, 180-181.

213 Georgopoulou 2001, 262-263. About the banner of Francesco Morosini, see Vokotopoulos 1981, 268-275. 


\subsection{The Franciscan Monastery of St Francis}

The Franciscan monastery of St Francis in Candia was one of the most important Franciscan monasteries of the entire province of Romania and, perhaps, of the entire East. ${ }^{214}$ The monastery was located in the south-east, inside the city walls, in a prominent location on the highest hill of the city and thus visible to anyone approaching from sea or land (Fig. 73). It was destroyed by an earthquake in $1856 .{ }^{215}$ The friary's site is presently occupied by the Heraklion Archaeological Museum (Fig. 74). ${ }^{216}$

As we have seen above, the mendicant orders enjoyed privileges in the Venetian-ruled territories: the Franciscans and the Dominicans had the right to preach, hear confessions and bury laymen in their churches, while their monasteries were autonomous establishments, exempt from the jurisdiction of local bishops and civic authorities. ${ }^{217}$ Benefitting from the relative political stability under Venetian governance, Crete became the greatest centre of Western monasticism in Greece. ${ }^{218}$ The Franciscans had established

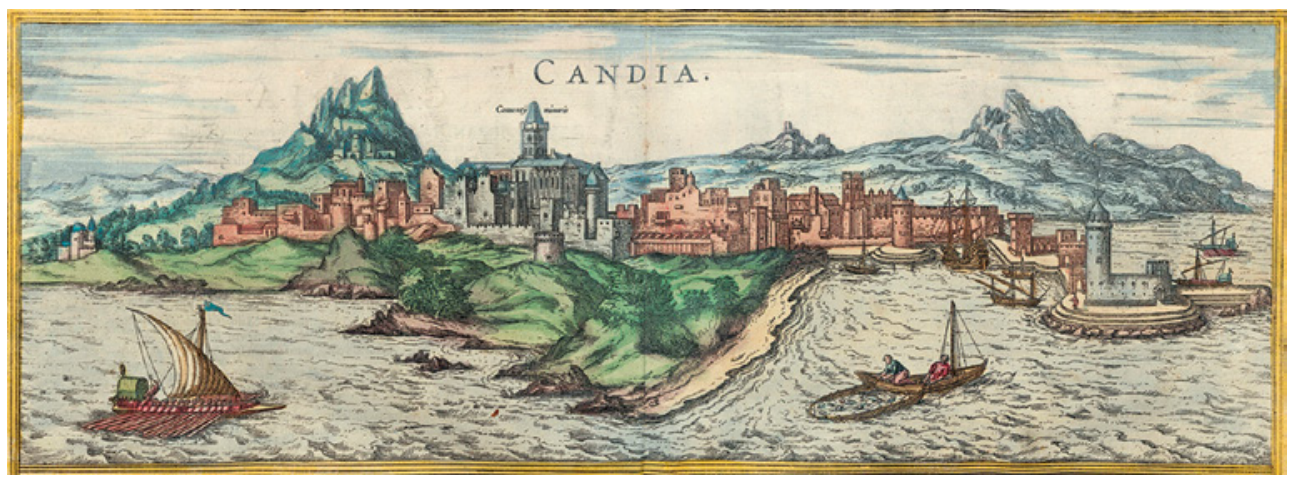

FIGURE 73 The Franciscan monastery of St Francis, standing out in the view of Candia, c. 1575, engraving

214 Tsougarakis 2012, 111; Kitsiki-Panagopoulos 1979, 93. Significant work on the church of St Francis of Candia has been undertaken by Donal Cooper, soon to be published in the journal Frankokratia, in the forthcoming 2022 special issue dedicated to the mendicants in Heraklion.

215 Georgopoulou 2001, 133; Tsougarakis 2012, 111; Kitsiki-Panagopoulos 1979, 93; Gerola 1932, 313; Xanthoudides 1964, 59 .

216 Remains of large arches that were probably part of the conventual building, as well as some sculptural fragments of the church's ornate west façade, were preserved on its north side. Georgopoulou 2001, 133; Tsougarakis 2012, 111.

217 Georgopoulou 2001, 132; Pagratis 1999, 113-116. About the religious orders in Greece, see Tsougarakis 2012, esp. 275-310.

218 Tsougarakis 2012, 111. 


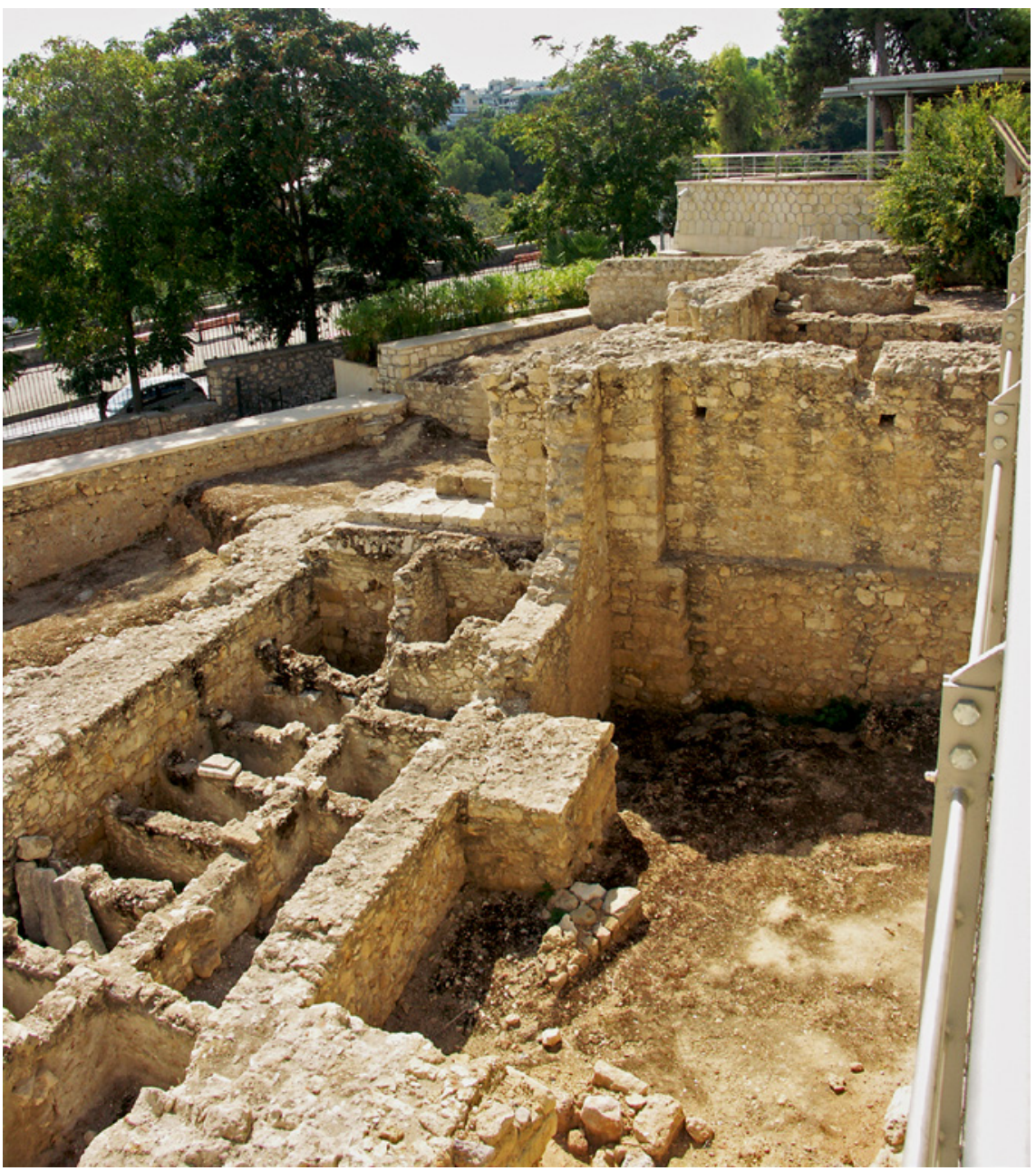

FIGURE 74 Remains of the Franciscan conventual church preserved at the site of the Heraklion Archaeological Museum

monasteries in all the major towns of Crete, while in Candia there was more than one monastery. ${ }^{219}$ This is also testified by several pilgrims visiting the town..$^{220}$

219 The major orders established their presence on Crete from the first years of Venetian rule, and by the 16th century 11 conventual churches stood in Candia. Tsougarakis 2012, 119; Georgopoulou 2001, 132.

220 Wilhelm Tzewers (1477-1478) writes: 'Sunt ibi Minores reformati in magno et parvo loco. In parvo loco circa hospitale Minorum est vitis, que septem fructus producit in anno. Vidi in ea flores et comedi de ea uvas maturas. Habuit agrestam et quasi maturos botros.' 
The exact date of the monastery's construction, as well as the circumstances of its foundation, remains unknown. It was already standing in 1242, since a surviving document mentions the burial of a nobleman in its church in the same year, but, considering that the first Franciscan missions started arriving in Greece in 1220 and that other orders had already established themselves on Crete by that time, it would be plausible to assume that St Francis was founded earlier than that. ${ }^{221}$ As in the case of several Franciscan houses in Greece, the monastery of Candia was allegedly founded by St Francis himself during his stay on Crete on his way to the Holy Land. ${ }^{222}$ As an attestation of the saint's involvement in the erection of the complex, or at least of his presence at the monastery of Candia, the pious visitors of St Francis were shown a well in the priory's garden that was, according to the legend, built by the saint himself, a tradition that also survived in the pilgrims' narratives. ${ }^{223}$

The monastery of St Francis soon became one of the more prosperous institutions of the town. The surviving inventories of its liturgical vestments and vessels, as well as lists of relics and catalogues of bequests of property to the monastery, show the measure of the monastery's wealth. ${ }^{224}$ It also possessed a significant library, whose holdings have been preserved along with the aforementioned inventories. ${ }^{225}$ The most famous benefactor of the monastery was Pope Alexander V, a Franciscan friar from Candia - in fact, an orphan who had been taken in and educated by a friar of the order. Pope Alexander endowed St Francis with precious relics, among which a part of the column of the flagellation, sacred vessels, a private chapel bearing his coat of arms and elaborate marble doors, crafted in Rome. ${ }^{226}$ Among others, the monastery possessed the arm of St Simeon, a fragment of the True Cross, the head of St Stephen, a phial containing the blood of St Bernard and a piece of the habit of St Francis. In

Hartmann 2004, 104. The existence of two monasteries is also attested by the anonymous French pilgrim who travelled in 1480, the German Dominican friar Felix Fabri (1480, 1483-1484) and Nicolas Loupvent in 1531. Hassler 1843-1849, vol. 3, 282; Schefer 1882, 49; Bonnin 1976, 6 o.

221 Tsougarakis 2012, 112.

222 As already mentioned, the monastery of St Francis in Corfu was also said to have been founded by the saint. Georgopoulou 2001, 133; Tsougarakis 2012, 112; Gerola 1932, 303; Moorman 1983, 105. According to another tradition, the monastery of Candia was founded by two Candiot Franciscan brothers, Petrus and Franciscus Gradonico. Tsougarakis 2012, 112, n. 34; Gerola 1932, 311.

223 See p. 211 below.

224 Georgopoulou 2001, 133, nn. 8-10; Tsougarakis 2012, 112-113; Gerola 1903, 243-245.

225 Tsougarakis 2012, 116.

226 Georgopoulou 2001, 134; Tsougarakis 2012, 118; Gerola 1932, 314-318. 
addition, the church housed and put out for public veneration an icon of the Virgin painted by St Luke. ${ }^{227}$

At some point in the 15th century, before 1431, the monastery was handed over by the Conventuals to the Observants. ${ }^{228}$ By that time, it was already very prosperous and popular in the city. In fact, this was one of the most interesting achievements of the Franciscan Order on Crete: the growth of the cult of St Francis among the Orthodox population. As detailed in a papal bull dating from 1414, on the saint's feast day the Greeks, along with their priests, flocked in vast numbers to St Francis and celebrated mass in their own rite. ${ }^{229}$

As far as the conventual buildings and church are concerned, as already mentioned they are no longer extant. However, thanks to its prominent position on top of the highest hill of the town, the monastery is portrayed in every view of Candia (see Figs 6o, 61). These depictions, combined with reports and inventories, allow for a reasonably safe reconstruction of the monastery, despite its demolition in the 19th century. ${ }^{230}$ The monastery's conventual church was a three-aisled basilica with a projecting transept, while at the east it ended in a tripartite apse or a chevet. ${ }^{231}$ It had two storeys, although its elevation may have been partial due to the limited space available. ${ }^{232}$ The main church was covered by a timber roof, and, according to the rules of the statutes, only the presbytery was vaulted. ${ }^{233}$ In the early $15^{\text {th }}$ century the three axial chapels

227 Georgopoulou 2001, 134; Tsougarakis 2012, 112-113. A list of the relics transferred from St Francis of Candia to Venice before its occupation by the Ottomans is published in Gerola 1903, 242-245.

228 Moorman 1983, 105.

229 Tsougarakis 2012, 117; Georgopoulou 2001, 135, n. 2. The text is published in Gerola 1932, 302, n. 4. As has been argued, the popularity of St Francis on Crete among the Orthodox grew to a large extent during the Venetian period. Besides the 15 th-century papal bull, the appearance of St Francis in the murals of a number of Greek churches on Crete, as well as the relatively frequent use of names and surnames deriving from Francis, have been used as arguments in favour of the aforementioned. Tsougarakis 2012, 117-118; Lasithiotakis 1981, 149; Gerola 1932, 301-302.

230 Valuable information about the interior of the church, its altars and chapels, as well as the liturgical vestments and vessels, is found in the report of the Latin Archbishop Luca Stella in 1625 , an inventory recording the possessions of the monastery compiled in 1417 , with later additions, thus covering the first half of the 15th century, and an inventory of 1669 , after the translation of the monasteries possessions to Venice. See Georgopoulou 2001, 133, nn. 8-10; Tsougarakis 2012, 112-113; Gerola 1903, 243-245.

231 Georgopoulou 2001, 133; Xanthoudides 1964, 59.

232 Georgopoulou 2001, 133.

233 Georgopoulou 2001, 133. The rule against vaults over the nave and aisles (mentioned after 126o in the Franciscan statutes) even forbade vaults over the choir, except over the apse itself. Kitsiki-Panagopoulos 1979, 65. About the Franciscan regulations on art and architecture, see also Sundt 2019. 
were dedicated to St John the Baptist, St Francis and the Holy Sacrament, while there were six or eight additional chapels along the lateral walls. ${ }^{234}$ Under the choir there was a crypt that housed a number of tombs. A 15th-century inventory catalogues a number of bequests of property to the monastery from members of the most prominent noble families of Candia, containing arrangements to be buried in the monastery's cemetery or in private altars in the church, as well as provisions for annual or daily prayers to be said for their souls. ${ }^{235}$ Such an incident is described by Jodocus von Meggen in 1542. The Swiss pilgrim, while recounting his visit to St Francis and the service held there in memory of his deceased uncle, provides information about the crypt:

There is this monastery of St Francis, which is an excellent temple, in which my uncle Giovanni of Meggen was buried, who, while travelling to Jerusalem got hit by pirates with a lethal arrow, and died, in the prime of his life. There, I took care of the performance of the sacred divine rites in his honour, according to the Christian custom. There, we saw under the said temple an underground crypt, where the bodies of the deceased are preserved, without decay or putrid odour, locked up in wooden and iron chests. ${ }^{236}$

Despite obviously following the Western architectural and liturgical setting, it seems quite possible that the priory had decorative elements of a Byzantine manner as well. According to Giuseppe Gerola, the walls of the church were decorated with frescoes in a Byzantinising style. ${ }^{237}$ The most probable hypothesis, taking also into consideration the inventory of the monastery's possessions

234 According to surviving documents, the chapel of St Francis was endowed by Franciscus Caravello in 1371. The available material does not provide sufficient information to establish the locations of the lateral chapels with certainty. According to 15th-century notarial documents and inventories, they were dedicated to St George, St Michael, St Nicholas, St Mark and the Virgin. They also contain information about altars endowed by George Bolani, the Caravello family and the monastery's grand benefactor, Pope Alexander v. According to the report of Luca Stella and an inventory of 1669, there was also a chapel dedicated to a major Franciscan saint, St Anthony of Padua. Georgopoulou 2001, 133, nn. 8-9.

235 Tsougarakis 2012, 113 .

236 'Est hic \& religiosum B. Francisci coenobium, templum que eximium, in quo auunculus meus Ioannes à Meggen, florente aetate, quondam Hierosolyma rediens, cum à pyratis laetali spiculo ictus esset, atque diem obijsset, sepulturae traditus est. Ego sacra illi diuinaque officia, pro eo ac debebam, Christiano more celebrari curaui. Vidimus illic sud ipso templo subterraneam cryptam, vbi defunctorum cadauera ligneis arcis, siue ferreis inclusa, sine putredine \& foetore diutius conseruantur.' Von Meggen $1580,55^{-} 56$.

237 Gerola 1908, 114-115. 
that were transferred to Venice before 1669 , would be that the interior of the church reflected the particularities of art appreciation in 16th-century Crete: it would have been adorned with panels and works of art of Cretan and Venetian artists that would be both maniera greca and maniera latina. ${ }^{238} \mathrm{~A}$ 17th-century document attests to the existence of 'ancient' paintings at least in the second chapel, dedicated to St George, one of which, depicting St Francis and St Dominic embracing, survived to $1653 .{ }^{239}$ The fact that the painting is referred to as very old (antichisima) could be an indication of a probable Byzantine style. According to the same document, a similar and equally 'ancient' painting existed in the Dominican monastery of St Peter the Martyr, constituting a link between the two most important monasteries of the town. ${ }^{240}$

In any event, the interior of the church would have been exceptionally well-structured and ornate, since, besides the aforementioned descriptions and inventories that reflect its wealth and possessions, pilgrims do not omit to praise the elaborate and beautiful monastery. ${ }^{241}$ In 1480 the French pilgrim Pierre Barbatre writes: "The most beautiful, honoured and big church is the one of the Franciscan brothers; in it there are many beautiful chapels, a beautiful

238 Gerola 1908, 115; Gerola 1932, 316; Georgopoulou 2001, 134. About the inventory containing a list of religious paintings transferred to Venice from the monastery of St Francis of Candia, see Gerola 1903, 243-245.

239 'Ritrovasi nella chiesa di san Francesco di Candia [...] nella capella seconda nel nell'usir fuori della sacrestia, intitolata san Georgio, a man dreta nel intrar in quella, una pitura di santi Francesco et Dominico che stano in atto di abraciarsi, di altezza di statura di sette quarti in circa [...].' Continuing, the writer of the document describes the painting as follows: '[...] et si osserva in quella di san Francesco esser vestita d'habito capucino, cio è col capucio piramidale che ariva sino alla centura et senya alcun segno di luneta o scapulare et questa pitura s'ha per sicura tradicione esser antichisima [...]'. Konstandoudaki $1975,131$.

240 'Ritrovandosi nella sacristia della nostra chiesa nel monasterio di San Piero di Candia dietro, la porta che entra dalla chiesa in sacristia, una pitura delli santi Domenico et Francesco che mostrano star abrazati [...]' The embrace of St Francis and St Dominic in front of the doorway of St Peter in Rome is a popular iconographical theme in Western art. Its 'invention' was attributed to the Dominican friar Thierry d'Apolda, while it appeared in Italian art in the 15th century. Konstandoudaki 1975, 132, 134; Kirschbaum and Braunfels 1974, col. 276 .

241 In 1480 the anonymous French pilgrim characterised the monastery as 'la plus belle'. Schefer 1882, 49. In the same year Pierre Barbatre writes: '[...] la plus belle eglise et la plus honneste et grande est celle des freres de sainct Françoys.' Pinzuti and Tucoo-Chala 1972-1973, 123. In 1493 Jan Hasištejnsky of Lobkovice reports it was clean and huge: 'A gest welmi czisty, weliky a czistie vstaweny klasster'. Strejček 1902, 35. Several other pilgrims attest to the aforementioned: Pietro Casola (1494), Jacques Le Saige (1518), Nicolas Loupvent (1531) and Denis Possot (1532). Paoletti 2001, 151; Duthill 1851, 81; Bonnin 1976, 56 ; Schefer 189o, 129 . 
choir, pulpit, organ, cloister and more; and it is located adjoining the eastern city walls.'242 In 1494 the Italian Pietro Casola also praised the Franciscan monastery: 'The most beautiful is the church of St Francis, of the Observant brothers; it is more appealing than the cathedral; it has a beautiful choir, with three rows of elaborately carved stalls and its beautiful monastery.'243

The west façade of the church had an elaborate portico preceded by a semicircular staircase. Fragments of its decoration, a bust of Christ and one of an angel, are exhibited in the Historical Museum of Crete in Heraklion. ${ }^{244}$ A bell tower stood to the south of the church, while next to it there was an octagonal building, probably a baptistery, and a marble column adorned with a sphere at its top. ${ }^{245}$ As far as the other conventual buildings are concerned, mentions survive about the dormitory, which had a large portico, as well as an infirmary that was donated by Johannes Greco in $1417 .{ }^{246}$

During the course of its history, the monastery was rebuilt at least twice, in the 14th and the 16th centuries, when, in 1508, it suffered severe damage from an earthquake. The friars resided in it until the island's occupation by the Ottomans. ${ }^{247}$ Following 1669 , the conventual church was converted into a royal mosque, the Hunkâr Cami (Fig. 75). In 1856 it was almost completely destroyed by an earthquake; later on it was demolished, and its building material was

242 '[... ] la plus belle eglise et la plus honneste et grande est celle des freres de sainct Françoys; en icelle sont plusieurs belles chapelles, beau ceur, pulpitre, orguez, cloistre et aultres; et est joingnant des murs de la cité vers midy.' Pinzuti and Tucoo-Chala 1972-1973, 123. The monastery's organ also impressed the French pilgrim Nicolas Loupvent: 'On nous monstrat au grantz cordeliers les plus belles orgues de crestienté; les a faict maistre Vincent Columbe de Montsarat.' Bonnin 1976, 6 o.

243 'E più bello li sii è la giesia de Santo Francesco di frati Observanti; è più bella cha la giesia cathedrale; ha uno belissimo coro, con li stadii triplicati, a chi non sono mancati li belli intagli, con lo suo bello convento.' Paoletti 2001, 151 .

244 Georgopoulou 2001, 134; Gerola 1932, 316; Xanthoudides 1964, 59.

245 Gerola 1932, 317; Georgopoulou 2001, 134; Xanthoudides 1964, 59.

246 Georgopoulou 2001, 134, n. 13.

247 The monastery's church was demolished in the mid-14th century, and plans were made for an extravagant replacement. However, it seems that Friar Raphael, the provincial minister of Romania, usurped a large amount of the monastery's money for this purpose, causing the involvement of Venice and the pope. The monastery was eventually rebuilt with the aid of two government grants, one of 25 hyperpera and a second one amounting to 1000 hyperpera in 139o. Tsougarakis 2012, 117; Georgopoulou 2001, 133; Kitsiki-Panagopoulos 1979, 93; Gerola 1932, 312-313; Xanthoudides 1964, 59; Gerola 19o8, 112. The document mentioning the grant of 1000 hyperpera pro fabrica ecclesie is dated 13 June 1390 and is published in Fedalto 1978, 141, no. 350. 


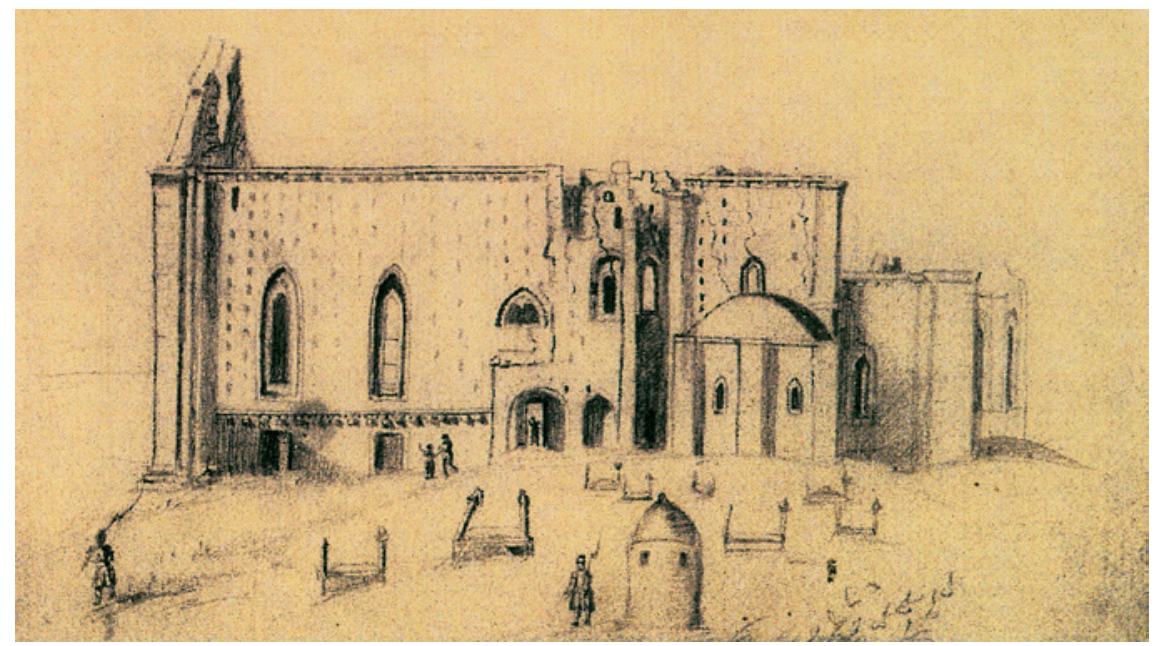

FIGURE 75 The church of St Francis as a mosque after the earthquake of 1856, after A. Alexandrides

used for the reconstruction of the Vezir Cami. ${ }^{248}$ Today, only a photograph and two architectural drawings of the monastery survive. ${ }^{249}$

\subsubsection{Collection of Relics}

As briefly mentioned above, the Franciscan monastery of St Francis of Candia owned an impressive collection of relics. Christological mementoes, saintly bodies and a Lucan icon, as well as mementoes of St Francis, were housed and displayed for public veneration in the conventual church.

\subsubsection{Christological Relics}

Christological relics were considered to be especially significant. Material remains that claimed physical contact with the body of Christ and were associated with events related to his life and Passion served as a mediator of a partial, figurative translation of Jerusalem. ${ }^{250}$ In the 15 th century, during the papacy of Alexander v, the monastery of St Francis acquired one of its most significant relics: a piece of the column of the flagellation. This relic was showcased in a large elaborate silver reliquary with enamels of the Crucifixion, the

248 Georgopoulou 2001, 133; Kitsiki-Panagopoulos 1979, 93; Gerola 1932, 312-313; Xanthoudides 1964, 59; Gerola 1908, 112.

249 The architectural drawings of the monastery made by Antonios Alexandrides in 1866 depict the remains of the monastery after the earthquake. Gerola 1908, 114-116; Georgopoulou 2001, 135, fig. 87 .

25 O Bacci 2017a, 135; Klein 2010, 56-57. 
Virgin and St John on one side and Sts Anthony, Christopher and Andrew on the other. ${ }^{251}$ The reliquary and its precious contents were transferred to Venice along with the rest of the relics of the monastery, as attested by the inventory published by Giuseppe Gerola. ${ }^{252}$

The monastery's collection of Christological relics was completed with fragments of the golden doors through which Christ entered Jerusalem, as well as a piece of the True Cross, the ultimate contact relic, the actual instrument of the Passion. Those precious material mementoes of Christ's presence on earth gave the pilgrims the opportunity to evoke the cultic attractions they expected to see in Jerusalem in a synecdochical way; and it was through these relics that the friars of Candia transplanted some of the holy stones that shaped the Holy City's material body onto Cretan soil. 253

Pilgrims' mentions of the Christological collection of the Franciscan monastery are fewer than one would expect, given the significance of the relics. All

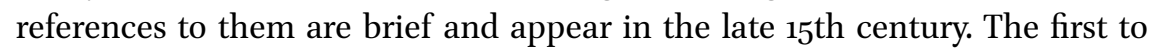
mention the True Cross was the Italian Antonio da Crema (1486) and almost a decade later the Bohemian diplomat Jan Hasištejnsky of Lobkovice (1493). ${ }^{254}$ Following Hasištejnsky's reference, four other pilgrims indicate seeing fragments of the golden door and of the column of the flagellation in the conventual church, while no other mentions or descriptions of the collection of the Franciscan monastery have survived in the travelogues. In regard to the Christological relics housed in the church of St Francis, it should be noted that in 1519 the Swiss pilgrim Ritter Melchior also attests to seeing a nail from the True Cross in the church of St Francis. ${ }^{255}$

\subsubsection{Saintly Relics}

According to the inventories, the Franciscans of Candia possessed and displayed for public veneration several saintly relics: the arm of St Simeon, the

251 Georgopoulou 2001, 134; Tsougarakis 2012, 113. The document of the 15th-century inventory, as published by Maria Georgopoulou, reads: 'In primus unum quadrum magnum de argento cum smaltis ab una parte crucifixum et verginem et beatum iohannem launtibus et ab alia parte sanctos Antonium, Christofori et Andrea et intus est unum magnum pecium columpne Christi et hanc donauit conuentui dominus papa Allexander [sic] quintus.' Georgopoulou 2001, 134, n. 16.

252 'Instrumentum pacis argenteum, in quo asservatur pars columne flagellationis Domini Nostri Jesu Christi, missa in ipsamet argentea capsula a prefato summon pontifice Alexandro.' Gerola 1932, 243.

253 Bacci $2017 \mathrm{a}, 135$.

254 '[...] una crocetta del ligno di la croce dii nostro Salvatore'. Nori 1996, 140. '[...] kus krzize pana Krysta'. Strejček 19o2, 35 .

255 '[...] ein form des nagels vom helgen crücz'. Schmid 1957a, 47. 
head of St Stephen, a phial containing the blood of St Bernard, a piece of the habit of St Francis and the tibia of St Lawrence. All of these were among the treasures of the monastery that were transported to Venice before the island's occupation by the Ottomans. ${ }^{256}$

The relic that amasses the majority of the pilgrims' mentions in regard to the Franciscan monastery of Candia is the head of St Stephen, followed by St Simeon's arm. However, the latter is not recognised by all of the travellers as belonging to Simeon the Wise; a number of the pilgrims attribute the relic to St Simon the Zealot. As far as the rest of the relics are concerned, they are all mentioned within the period between 1493 and 1525, always in a form of a list, by five pilgrims. The most complete list of the collection of the Franciscan friary was provided by the German Alexander von Pfalz-Zweibrücken (14951496): 'St Stephen's head; St Simeon's arm; an icon of the Virgin painted by St Luke; a piece of the column to which our Lord was bound; a piece of the golden Gate of Jerusalem; a piece of the habit of St Francis; the blood of St Bernard; a piece of the True Cross and many other holy relics.'257

St Stephen is traditionally venerated as the protomartyr of Christianity. According to the Acts of the Apostles, he was a deacon in the Early Church of Jerusalem who was accused of blasphemy and was stoned to death. According to the same source, 'Godly men buried Stephen and mourned deeply for him.'258 His relics were subsequently miraculously retrieved and were soon disseminated to a large number of churches around the world. ${ }^{259}$ On Crete the saint's relics appear to have been kept in the town's Latin cathedral, at the altar erected above the tomb of the Archbishop Fantinus Vallaresso in 1446. ${ }^{260}$

However, and while only one pilgrim attests to seeing the protomartyr's relics in the church of St Titus, several other religious travellers, all after the late 15th century, report seeing St Stephen's head in the conventual church of the Franciscans of Candia. In fact, some of them also attest to being able to see the marks made from the stones that led to the saint's death on his cranium. At the beginning of the 16th century (1500-1504), Pietro Paolo de Rucellai

256 Georgopoulou 2001, 134; Tsougarakis 2012, 118. The list of relics transferred to Venice is published in Gerola 1932, 314-318.

257 'De haben meine G.H. gesehen das Heiligtum: St. Stephans Bischofs Haupt; St. Simeons Arme; ein Bild nach unserer lieben Frau, das St. Lux gemalt hat; von der Säule, daran unser Herr gebunden war; ein Stück von der goldenen Pforte zu Jerusalem; ein Stück von St. Franziscus Rock; von St. Bernhards Blut; ein Stück von dem heiligen Kreuz und viel anderes Heiligtum.' The German duke was also the first pilgrim to attest to the existence of a Lucan icon in the Franciscan monastery of Candia. Karbach 1997, 59 .

258 Acts 8:2.

259 About the relics of St Stephen, see Hunt 1981.

26o Georgopoulou 1994, 112; Georgopoulou 2001, 112; Georgopoulou 2013, 145. 
wrote: 'In the capital city there is a beautiful monastery of the Observants of St Francis, where the noble relic of the head of St Stephen, first martyr of Christ, is kept: and one can see the percussions of the stones that trod and broke the bone towards the brain of St Stephen.'261

Thus, in regard to the whereabouts of the relics, it would be plausible to assume that either the arm of St Stephen was kept in the town's cathedral and his head at the Franciscan monastery or that the saint's relics, although they first appeared in the cathedral of St Titus, were transferred at some point in the 15th century to the Franciscan monastery, since a number of pilgrims attest to their presence in the church of St Francis. In addition, while in the inventory of February of 1669, listing the relics transferred to Venice from the Latin cathedral of Candia, there is no reference to St Stephen's relic, the analogous inventory of St Francis mentions the head of St Stephen the protomartyr, 'well covered in silver with many ornaments and precious stones, placed in a golden silver vase of noble shape and with many images and Greek letters carved around the vase. ${ }^{262}$

Whatever the case may be, St Stephen's relic soon became the most mentioned relic of the Franciscan monastery. Most probably, the rise of the relic's fame and the fact that it started appearing in the travelogues from the end of the $15^{\text {th }}$ century was due to its 'promotion' by the friars. The impressiveness of the monastery's collection of relics is a clear indication of the Franciscans' interest in attracting the pious, both locals and pilgrims, and promoting their monastery, and this seems to have been especially exploited after the monastery was handed over to the Observant branch of the order. ${ }^{263}$

The second most mentioned relic housed in the church of St Francis was the arm of St Simeon. He was the one who held the Christ Child at the time of the Presentation at the Temple and uttered the famous prayer of praise beginning with the words Nunc dimittis servum tuum, Domine. As most of the pilgrims attest, the prophet's relic was housed and venerated in the church of St Mary the Major in Zadar from the 13th century, rendering the church an international pilgrimage site and certainly the most popular pilgrims' destination of the

261 'Nella città principale è un bel Convento dell'Osservanza di Santo Francesco, dove è quella nobile reliquia del teschio di Santo Stefano, primo martire di Cristo: et vedesi due percussioni di quelle pietre, le quali calcarono et infransero l'osso verso il cervello a Santo Stefano.' Da Civezza 1879, 5 o7.

262 'Cranium S. Stephani protomartyris, bene in argento ligatum cum multis ornamentis et lapidibus valoris, repositum in vase argenteo inaurato nobilis forme, cum plerisque imaginibus ac litteris grecis circa vas ipsum insculptis.' Gerola 1903, 243.

263 The monastery was handed over from the Conventual to the Observant branch of the order in the 15th century, probably before 1431. Moorman 1983, 105; Bacci 2017a, 145 . 
town. ${ }^{264}$ Additionally, the saint's relics were also claimed by Venice, whereas in the port of Ragusa the cloth upon which the newborn Jesus was laid was venerated. ${ }^{265}$ The travellers following the sea route from Venice to Jerusalem, having already visited the aforementioned sites, were informed, upon arriving in Candia, that the arm of St Simeon was kept in the Franciscan monastery of the town.

The arm of St Simeon appears in the monastery's inventories from the 15th century, while it was among the ones transferred to Venice before the island's occupation by the Ottomans. ${ }^{266}$ According to the inventories, the relic was coated in pure silver at the expense of Marco Trevisan, provincial minister of Romania. ${ }^{267}$

Most of the pilgrims mentioning the monastery refer to this relic. St Simeon's arm is mentioned in five travelogues, between the years 1486 and 1525 . However, only one of the pilgrims, Alexander von Pfalz-Zweibrücken (1495-1496), identifies it as the relic of Simeon the Wise. The other four pilgrims, Antonio da Crema (1486), Boguslav of Lobkowitz (1493), Duke Frederick of Legnica and Brieg (1507) and Arent Willemsz (1525), while all reported to have seen it, do not actually refer to St Simeon the Prophet, but to Simon the Apostle, also known as the Zealot, and celebrated along with the Apostle Jude Thaddeus. Thus, Antonio da Crema refers to the 'arm of St Simon the Apostle', Boguslav of Lobkowitz to 'an arm of St Simon and Jude', Duke Frederick of Legnica and Brieg to 'the right arm of St Jude Thaddeus' and Arent Willemsz to 'the arm of St Simon, brother of Judas'. ${ }^{268}$ Given the fact that both the 15 th- and 17th-century inventories refer to the arm of St Simon the Apostle (brachium Sancti Simeonis apostoli), it would be plausible to assume that the identification of the relic kept and venerated in the Franciscan conventual church with St Simeon the God-receiver could have been a - deliberate or not - misunderstanding that

264 About St Simeon's relic and the church of St Mary the Major, see Bacci et al. 2018, 363-367.

265 Bacci et al. 2018, 368-369; Bacci 2017a, 144-145.

266 Georgopoulou 2001, 134, n. 17; Tsougarakis 2012, 113; Gerola 1932, 314-318.

267 Tsougarakis 2012, 113. The text reads: Item brachium Sancti Simeonis apostoli totum copertum de puro argento totum de arger auratum pulchro opera quod brachium fecit fieri reverentus in Christo pater frater Marcus Riuisano de Veneciis, minister prouincie Romanie'. Published in Georgopoulou 2001, 134, n. 17.

268 Antonio da Crema (1486): ‘[...] uno brazo de sancto Simone apostolo'. Nori 1996, 140. Boguslav of Lobkowitz (1493): 'So Ssimonisse Judy hnat z ruky'. Strejček 1902, 35. Duke Frederick of Legnica and Brieg (1507): '[...] der Rechte Arm des Heiligen Judae Thadej.' Röhricht and Meisner 1878, 120. Arent Willemsz (1525): 'Den Arme van sinte Symon Judas broeder. Gonnet 1884, 55 . 
actually elevated the relic, connecting it to a highly venerated saint, whose body was claimed by both Venice and Zadar. ${ }^{269}$

The Franciscans of Candia also possessed and displayed for public veneration a Lucan icon of the Virgin. The town of Candia and its cathedral, the church of St Titus, was already privileged to house a Byzantine icon of the Virgin attributed to St Luke, the palladium of the city, the icon known as the Mesopanditissa. The island and its capital had thus been integrated earlier into the subnetwork of Marian cult sites along the sea route leading from Venice to the Holy Land. 270 The Lucan icon of the Franciscan monastery appears for the first time in the travelogue of Antonio da Crema (1486), who refers to an icon of the Virgin painted by St Luke, while up until the end of the time frame of this study only two other pilgrims mention the icon: Alexander von Pfalz-Zweibrücken (1495-1496) and Duke Frederick of Legnica and Brieg in 1507.271

Neither the travelogues nor the few surviving documents concerning the Franciscan monastery of Candia provide further information about the icon mentioned by the pilgrims. The last reference to the icon in relation to the monastery is in the inventory listing the relics and valuable possessions transferred from St Francis to Venice before $1669 .{ }^{272}$

The collection of relics of the Franciscan monastery of Candia was completed by mementoes of saints associated with Western Europe, their religious order and especially of their founder, St Francis. Besides the mementoes of St Francis, and among others, the monastery housed relics of the Franciscan saints St Bernard, St Bernardine of Siena and St John of Capistrano. Undoubtedly, the mementoes of the order's founder were the most precious and important, as, according to tradition, he was also the founder of the Candiot monastery: a piece of the habit of St Francis was exhibited in a silver reliquary adorned with precious stones and a large crystal. ${ }^{273}$ Four pilgrims mention

269 Georgopoulou 2001, 135, n. 19; Tsougarakis 2012, 113.

270 About the Marian cult sites on the same route, see Bacci et al. 2017.

271 Antonio da Crema (1486): '[...] una figura di la Madona picta demandi sancto Luca'. Nori 1996, 140. Alexander von Pfalz-Zweibrücken (1495-1496), see n. 257 above. Duke Frederick of Legnica and Brieg in 1507: '[...] auch ist alda in der Kirchen ein gang auff die rechte Hand ein bilde vnser Iieben frawen vnd man saget, dass es S. Lucas habe gemahlet, vnd ist ein klein bilde.' Röhricht and Meisner 1878, 120.

272 'Imago B. Virginis Marie a S. Luca evangelista depicte'. Gerola 1903, 245.

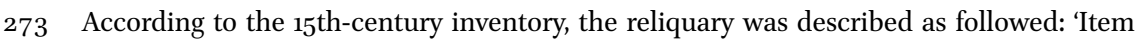
reliquarium unum pro tunica sancti Francisci pulchrum cum pede de argento cum vitibus releuate et ponium et lapidibus vitreis legatis cum uno magno et pulchro cristallo et una capite superius quod donauit conuentui frater Franciscus Sanuto'. Georgopoulou 2001, 135, n. 19; Tsougarakis 2012, 113 . 
seeing this relic between the years 1493 and $1525 .{ }^{274}$ In 1507 Duke Frederick of Legnica and Brieg added a piece of information, referring to a quadrate chapel where the reliquary was kept. 275

As pointed out by Michele Bacci, following the popularity of the worship of St Francis as the alter Christus, a network was formed in which the memorial sites connected with the saint's voyage to Egypt were integrated and worked as an extension of his own topography. ${ }^{276}$ As already mentioned, just as in many other cases of Franciscan monasteries in Greek territory, St Francis himself was according to tradition the founder of the Candiot monastery. This fact was exploited in Candia, since it allowed the friars to promote their monastery as a point of reference within the network. Pious visitors were led to the friars' garden, where they were shown the well that the saint himself had built during his stay on the island. Worship was directed towards a material object, sanctified by its prestigious provenance, and, at the same time, imbued with memorial meaning, since it bore witness to the saint's physical presence on Crete. ${ }^{277}$ Thus, the Franciscan monastery of Candia was presented as the only place where the holy topography of the alter Christus intersected with the network of venerable places that dotted the Venetian sea route to the Holy Land. ${ }^{278}$

Two pilgrims visiting St Francis of Candia refer to the well: Jacques Le Saige (1518) and Jodocus von Meggen (1542). The French pilgrim simply repeats the legend according to which the well was built by St Francis during his stay on Crete. $^{279}$ The Swiss pilgrim Jodocus von Meggen, who visited the friary in 1542, enriches the legend. He does not mention if the well was actually built by St Francis or not, but he attests to the saint's physical presence on the island and the friary by stating that he was the one who turned the well's water from salty into sweet and drinkable. ${ }^{280}$

274 Jan Hasištejnsky of Lobkovice (1493), Count Alexander von Pfalz-Zweibrücken and Johann Ludwig von Nassau-Saarbrücken (1495-1496), Duke Frederick of Legnica and Brieg (1507) and Arent Willemsz (1525). Strejček 1902, 35; Karbach 1997, 59; Röhricht and Meisner 1878, 120; Gonnet 1884, 55-56.

275 '[...] ein stücke von dem Rocke des H: Francisci, auch ist in einer gevirten Cabell.' Röhricht and Meisner 1878, 120.

276 Bacci 2017a, 145; Bacci 1991, 31-57.

277 Bacci 2017a, 145.

278 Bacci 2017a, 145. About the sacred topography of St Francis, see Bacci 2009.

279 'Il y a un puich derriere le coeur, lequel dissent quil vint miraculeusement a monseur sainct Franchois quant il demouroit la.' Duthill 1851, 81 .

28 o 'Huic loco puteus est vicinus sane nobilis, cuius aquam ob vicinum mare olim salsam, post S. Francisci benedictione \& prece in dulcem ac potabilem conuersam aiunt.' Von Meggen 1580, 56 . 
The significance of the collection of relics of the Franciscan monastery of Candia is not by any means reflected in the travelogues. Very few pilgrims appear to refer to it throughout the period of the 14th to the 16th centuries - in fact, all of the references to the monastery or the relics date from the late 15th century onwards - and even then with few, if any details or remarks. On the other hand, the narratives do provide new evidence about the monastery and its church, while they draw attention to a very clear boost in its popularity at the end of the 15th century, possibly linked to the enrichment of its relic collection through the donations made by Pope Alexander v, and to the taking over of the monastery by the Observant branch of the order around the middle of the century. In any case, the pilgrims' narratives attest to the existence and popularity of a rich and impressive collection of relics that would otherwise be known only through the monastery's inventories.

\subsection{The Dominican Monastery of St Peter the Martyr}

Like the Franciscan monastery, the Dominican monastery of Candia was one of the most celebrated Dominican monasteries of the entire province of Greece. ${ }^{281}$ It was located in the north-west part of the city, right on the waterfront and, as a result, it was highly visible to anyone approaching by boat (Fig. 76). The German Dominican friar Felix Fabri (1480, 1483-1484) writes: 'In this town, our preacher brothers have a beautiful monastery built near the walls of the city, right above the sea [...]', while he appears quite impressed by the fact that the friars lived and studied in cells where the sound of the waves breaking so near would alarm someone not familiar with it. ${ }^{282}$ The impressive church of the Dominicans, dedicated to St Peter the Martyr, after having been restored, still stands today in the northern part of the modern town of Heraklion (Fig. 77). ${ }^{283}$

The exact date of the monastery's construction, as well as the circumstances of its foundation, remains unknown. However, documentary material suggests that it was established towards the middle of the 13th century, during

281 About the Dominican monastery of St Peter the Martyr in Candia, see Gerola 1908, 125127; Tsougarakis 2012, 179-185; Kitsiki-Panagopoulos 1979, 87-93; Kitsiki-Panagopoulos 1981, 284-287.

282 'In eadem civitate fratres nostri praedicatores pulchrum habent conventum ad moenia civitatis supra mare [...]. Saepe miratus fui, quomodo fratres in illis cellis possent quiescere aut studere per confusionem sonitus maris et fluctuum, quia tantum facit aqua sonitum, quod homo proprium cantum aut vocem non audit.' Hassler 1843-1849, vol. 3, 281.

283 Beginning in 1972, the Greek Archaeological Service undertook restoration works at the Dominican conventual church. The works restored the building to its 16th-century appearance and not its original 13th-century condition. About the restoration of the church of St Peter, see Delinikola et al. 2008. 


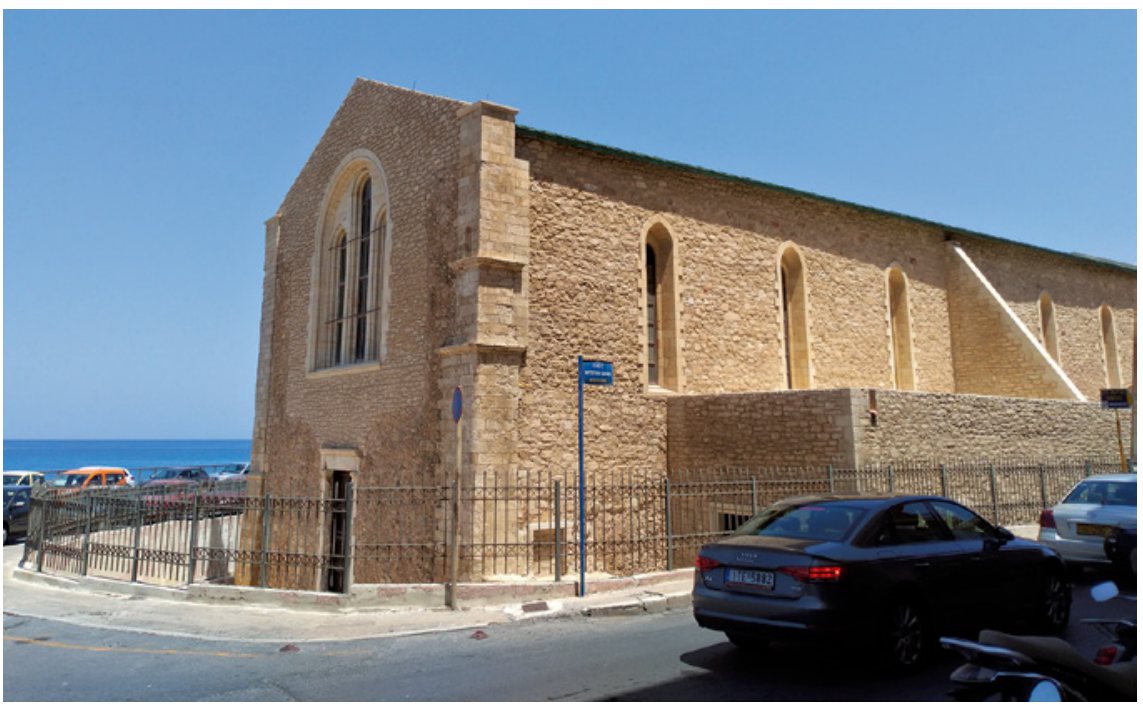

FIGURE 76 The Dominican monastery of St Peter the Martyr, Heraklion, view from the south-west

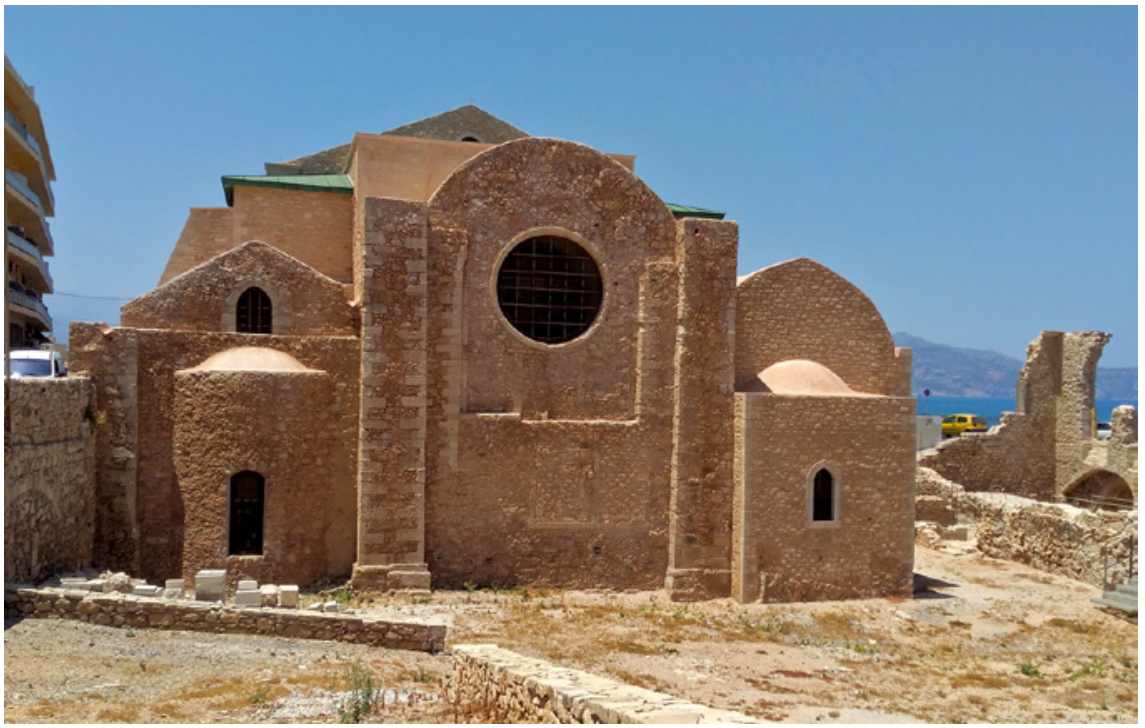

FIGURE 77 The Dominican monastery of St Peter the Martyr, Heraklion, view from the east 
the incumbency of the Dominican archbishop of Crete Giovanni Querini $(1247-1252) .{ }^{284}$ The monastery was constructed after the donation of a plot of land inside the town of Candia from the Venetian authorities in $1248 .^{285}$ The original dedication of the monastery's church is also uncertain, although most probably it was dedicated to St Peter the Martyr from the beginning. If this assumption is correct, then its foundation should be dated a few years after the donation of the land, since Peter of Verona (later St Peter the Martyr) died in $125^{2}$ and was canonised by Pope Innocent IV in $1253 .{ }^{286}$ Thus, the monastery must have been dedicated in the early to mid-125os.

The first generous donation of 1248 was followed by quite a few concessions of feudal lands that enriched the Dominican foundation in the second half of the 13th century. In the following century, the Venetian state even decided to make an annual donation of 25 hyperpera to the Dominicans of Candia to convene their provincial chapter. ${ }^{287}$ An extraordinary number of surviving wills, bequeathing money to the monastery, attest to the devotion that the Candiots showed to the house of St Peter. ${ }^{288}$ Many of the Venetians of the town, among them four dukes of Crete and several members of the nobility, chose the conventual church as their final resting place. Tombs for the most prominent citizens were erected inside the church, while many other citizens were buried in the church's courtyard. ${ }^{289}$

The monastery soon became one of the more prosperous institutions of the town, the only one to rival the popularity of the Franciscan monastery of St Francis. ${ }^{290}$ In the 14th century it was the seat of the provincial prior of Greece and his vicars, while it housed some of the inquisitors against heresy in

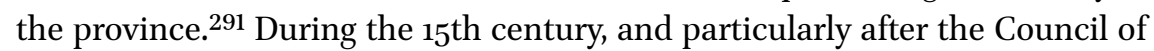
Ferrara-Florence, the Dominicans played an active role in pursuing the union

284 Tsougarakis 2012, 179; Georgopoulou 2001, 135-136; Andrianakis and Giapitsoglou 2012, 82.

285 Tsougarakis 2012, 179; Georgopoulou 2001, 136; Chronaki and Kalomoirakis 2004, 120; Andrianakis and Giapitsoglou 2012, 82 .

286 Chronaki and Kalomoirakis 2004, 121; Tsougarakis 2012, 179-180.

287 Further donations of land to the Dominicans of Candia were recorded in 1257, 1275 and 1301. Tsougarakis 2012, 179; Georgopoulou 2001, 136; Chronaki and Kalomoirakis 2004, 120-121.

288 At least 180 such wills from a period between the years 1312 and 1420 have been published. See McKee 1998, vol. 1, 345-346.

289 During the excavation works that were carried out, it was determined that the area in front of the church was used as a cemetery from the very beginning of the monastery's history up until the late 15th century. See Borboudakis 1968; Miles 1975. See also Tsougarakis 2012, 180; Georgopoulou 2001, 140; Chronaki and Kalomoirakis 2004, 122; Delinikola et al. 2008, 432.

290 Gerola 19o8, 126; Tsougarakis 2012, 181.

291 Tsougarakis 2012, 184-185; Chronaki and Kalomoirakis 2004, 122; Delinikola et al. 2008, 431. 


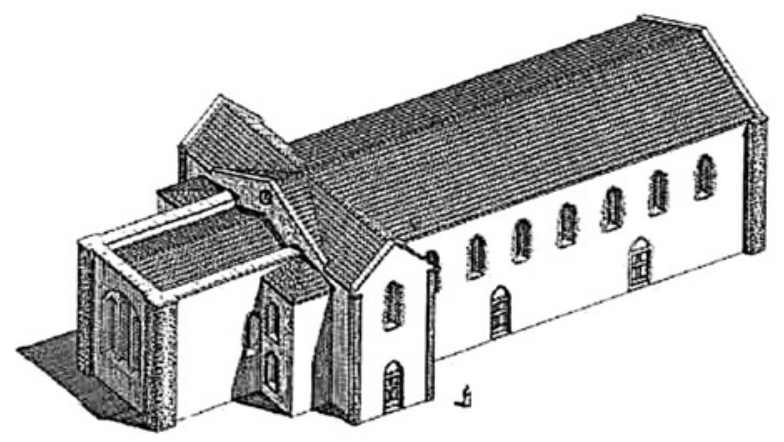

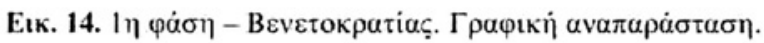

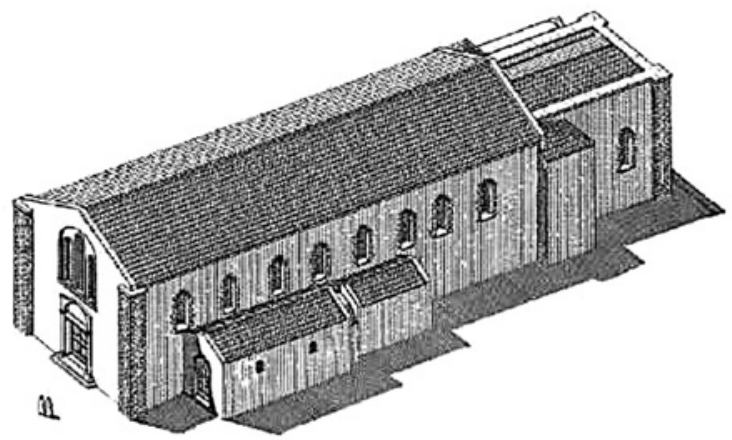

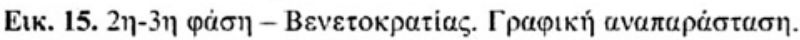

FIGURE 78 The building phases of the Venetian period of the monastery of St Peter the Martyr, Heraklion

of the churches. Finally, and thanks to its popularity and significant property, the monastery of Candia was also expected, like the Dominican monastery of Modon, to share in some of the provincial expenses in the late 15th century. ${ }^{292}$

The Dominican monastery, as well as two other Dominican houses that were founded in the city, survived until the end of the island's Venetian period. Following the Ottoman occupation in 1669 , it was converted into a mosque. ${ }^{293}$

The building of the conventual church of St Peter the Martyr has an austere and simple plan, with a square sanctuary and a two-storey elevation (Fig. 78). It has a large single nave that ends in a sanctuary with two bays. Its dimensions,

292 In 1487 the house was asked to contribute four ducats to help cover the expenses of the former provincial prior, Matthaeus of Venice, for his trip to the General Chapter. In 1491 the monastery was ordered to pay an annual sum for the studies of Friar Thomas of Candia. Tsougarakis 2012, 185 .

293 Tsougarakis 2012, 185; Georgopoulou 2001, 141; Andrianakis and Giapitsoglou 2012, 82; Chronaki and Kalomoirakis 2004, 124; Delinikola et al. 2008, 432. 
$41 \times 15 \mathrm{~m}$, are less than half of those of the Franciscan church. Its size, along with a lack of sculptural decoration and the austerity of the architectural plan, could point to a foundation poorer than the Franciscans. On the other hand, the simplicity in plan and decoration could be a result of the statutes of the order. ${ }^{294}$

The exact original form of the church of St Peter is hard to determine, as a great many changes have taken place since its construction. During a second building campaign that took place, it can be assumed, in the 14th century, two chapels were added on each side of the sanctuary, accessed by two large rounded arches. The choir was rib-vaulted, framed by a tall circular arch that also divided it from the nave. At the north angle of the choir stood a small vaulted chamber, probably used as a treasury. ${ }^{295}$ Two elongated side chapels were added along the south wall at a later date, while in one of them traces of wall paintings of female saints have been preserved (Fig. 79). ${ }^{296}$

The extension of the lateral walls of the nave, which abut onto the arcade between the nave and the sanctuary blocking the arched openings, may indicate a third construction period, most probably after the earthquake of 1508 . Additionally, the ribbed vault of the choir was replaced by a semi-circular barrel vault, and the west entrance was surmounted by a flat entablature. The exterior walls were pierced by numerous large windows, providing natural light to the interior of the church. ${ }^{297}$

Three sides of the church had entrances, while the courtyard in front of the main west entrance of the building was paved with slabs. ${ }^{298}$ The church also had a bell tower, as can be seen in all the medieval representations of the city (see Figs 6o, 61). The whole complex seems to have been enclosed by a wall, most probably constructed in $145^{\circ}$ to prevent visual contact with the neighbouring Jews. ${ }^{299}$ The proximity of the Dominican monastery to the Jewish quarter was commented upon by the pilgrims. The French priest Pierre

294 Kitsiki-Panagopoulos 1981, 285; Georgopoulou 2001, 136; Chronaki and Kalomoirakis 2004, 125-128; Delinikola et al. 2008, 43 .

295 Kitsiki-Panagopoulos 1979, 88-89; Georgopoulou 2001, 137; Chronaki and Kalomoirakis 2004, 129-132; Delinikola et al. 2008, 432.

296 The state of preservation is very poor and does not allow for an identification of the subject. Traces of wall paintings survived as well in the fourth southern chapel and on another section of the wall south of the central aisle. Chronaki and Kalomoirakis 2004, 123; Delinikola et al. 2008, 431-432; Georgopoulou 2001, 137.

297 The north wall, completely reconstructed in the 17th century, had twelve windows in two rows, while the south wall was pierced by eight windows, some of which could possibly be dated to the 13th century. Kitsiki-Panagopoulos 1979, 90-91; Georgopoulou 2001, 137-138.

298 Kitsiki-Panagopoulos 1979, 91; Georgopoulou 2001, 141.

299 Tsougarakis 2012, 179; Kitsiki-Panagopoulos 1979, 91; Georgopoulou 2001, 137-138. 


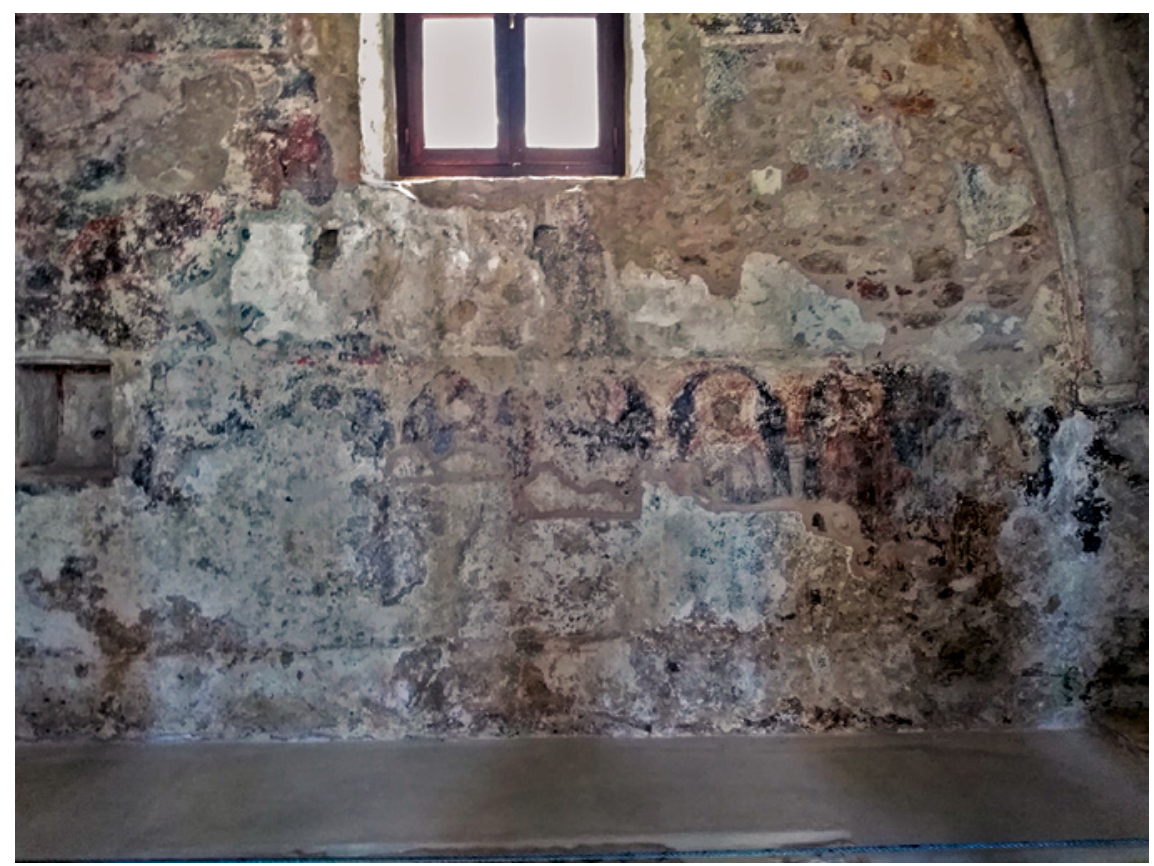

FIGURE 79 Traces of wall paintings in the south chapel of the conventual church of St Peter the Martyr, Heraklion

Barbatre, who visited the city in 1480 , mentions that ' [...] it is near the Jewish quarter, almost among the Jews $[\ldots]^{3}{ }^{300}$

As far as the interior of the building is concerned, very few material elements survive to attest to its form. It was, as mentioned above, well lit by several tall, large windows. According to a report of Archbishop Luca Stella in 1625, there were 11 altars inside the church, as well as a chapel dedicated to St Vincent in the courtyard. ${ }^{301}$ The numerous wills concerning the monastery also provide details of its interior arrangement, sections of which were sponsored by prominent Venetian families of Candia. ${ }^{302}$ Just like the town's cathedral and the Franciscan conventual church, the church of St Peter the Martyr also had an elaborate organ, installed in the 16th century and located above a vaulted chamber in a gilt case. ${ }^{303} \mathrm{An}$ interesting piece of information concerning the sacristy could be indicative of the way local Cretan and Byzantine tradition had

\footnotetext{
300 See $n .312$ below.

301 Georgopoulou 2001, 138.

302 Tsougarakis 2012, 181; Georgopoulou 2001, 138.

303 Georgopoulou 2001, 140; Chronaki and Kalomoirakis 2004, 123; Delinikola et al. 2008, 432.
} 
influenced the interior decoration of St Peter: a 17th-century document attests to the existence of a painting depicting St Francis embracing St Dominic that decorated the church's sacristy. The document, dated 13 June 1653, reads: '[...] in the sacristy of our church in the monastery of St Peter in Candia, behind the door that leads from the church to the sacristy, there is a painting of Sts Dominic and Francis embracing [...].304

According to this document, the painting existed from the beginning of the monastery, that is, 28 June $1097{ }^{305}$ As aptly pointed out by Maria Georgopoulou, the absurdly early dating of this painting most probably indicates that it was executed in a Byzantine manner. ${ }^{306}$ As discussed above, the same document attests to the existence of an analogous icon or fresco in the conventual church of the Franciscan monastery of St Francis, thus linking the two most important monasteries of the town and attributing to them, among others, the prestige of inveteracy, since these representations were emphasised as being antichisimi. ${ }^{307}$ The importance of the painting of the Dominican monastery was amplified by its miraculous preservation throughout the centuries: '[...] this painting is miraculously preserved from destruction; the others made at the same time have been destroyed, and this is the only one that remains intact.'308

The monastery's significance for the town of Candia, as well as for the province of Greece, is not really reflected in the pilgrims' narratives. Despite the fact that it amasses quite a number of references, most of them are restricted to a simple mention of its existence. The first pilgrim to mention the monastery of St Peter the Martyr is the Flemish diplomat Anselmo Adorno (1470-1471), who just refers to a Dominican monastery. Ten years later, the German Dominican friar Felix Fabri (1480, 1483-1484) dedicates several lines to the impressive structure of the monastery and its location right on the breakwater. The last mention of the Dominican monastery of Candia within the time frame of this study was made by the French Benedictine monk Nicolas Loupvent in 1531, again in the form of a passing reference.

During its history, the monastery underwent at least two large-scale reconstructions, in the 14th and the 16th centuries, when, in 1508, it suffered severe damage from an earthquake. The friars resided in it until the island's

\footnotetext{
304 'Ritrovandosi nella sacristia della nostra chiesa nel monasterio di San Piero di Candia dietro, la porta che entra dalla chiesa in sacristia, una pitura delli santi Domenico et Francesco che mostrano star abrazati [...]'. Konstandoudaki 1975, 132.

305 Konstandoudaki 1975, 132, 135 .

306 Georgopoulou 2001, 140; Konstandoudaki 1975, 132; Chronaki and Kalomoirakis 2004, 123.

307 Konstandoudaki 1975, 130-135, esp. 131-132. See also p. XX above.

308 ' [...] questa pitura si mantiene miracolosamente per esser distrute l'altre fatte nel medemo tempo, consumate, et questa sola resta intata.' Konstandoudaki 1975, 132.
} 
occupation by the Ottomans. Following 1669 the conventual church was converted into the mosque of Sultan Ibrahim Han. After the end of the Ottoman occupation, the building was used for public services until the 1970s, when it began to be restored. ${ }^{309}$

In contrast to the Franciscan monastery of the town, which owned and displayed an impressive quantity of holy objects, the Dominicans of Candia did not seem to have been known for an analogous collection. According to archival documents, in the 17th century in their conventual church one could see and prostrate to a piece of the robe of St Dominic and a bone of St Thomas Aquinas. In particular, an anonymous account dated to 1650-1655 mentions: 'There are some other relics, specifically a bone from the right index finger of St Thomas Aquinas and a small piece of the robe of St Dominic. ${ }^{310}$ However, none of the pilgrims who visited the monastery during the period within the time frame of this study refer to the existence of such relics or any other saintly remains being kept in the church of St Peter the Martyr, leading to the assumption that the aforementioned holy objects probably found their way to the Candiot monastery at some point during the course of the 17 th century.

Nevertheless, two very interesting mentions in the travelogues refer to an Acheiropoietos icon of the Virgin that was being housed in the church of St Peter. In particular, two French travellers (Pierre Barbatre and an anonymous pilgrim) who visited the town in 1480 mention seeing an icon of the Virgin 'painted by an angel.' ${ }^{311}$ The priest Pierre Barbatre gives more information than the anonymous French pilgrim:

In the town, near the sea, there is another church of the Dominicans, very beautiful and it is near the Jewish quarter, almost among the Jews, in which there is a painted image of the Virgin, painted by an angel; and on it the following is written:

309 The restoration of the Dominican conventual church was a long process that lasted until the first decade of the 21st century. About the history of the works carried out at the monument, see Chronaki and Kalomoirakis 2004, 125; Delinikola et al. 2008, 432; Tsougarakis 2012, 185; Georgopoulou 2001, 141; Kitsiki-Panagopoulos 1979, 87, 9 o.

310 'Vi sono alcune reliquie, particolarmente un osso dell'indice dextro del P. s. Tomaso d'Aquino et un poco della cappa del P. s. Domenico.' Loenertz 1944, 112. During the restoration works of the period from 1991 to 1995 , a medallion of St Thomas Aquinas came to light; it could be an attestation of the existence of the saint's relics in the Dominican conventual church. Chronaki and Kalomoirakis 2004, 124-125; Delinikola et al. 2008.

311 French anonymous (1480), '[...] une ymaige de Nostre Dame que ung ange a paincte'. Schefer $1882,49^{-} 5^{\circ}$. 
Qui primo candidissime gaudium indixit

Prehendicat nunc passionis signacula

Carnem vero chastus mortalem inductus

Timensque letum talia pavet cernendo. ${ }^{312}$

Neither of the two travellers referring to the icon provides any information about its form or spatial setting within the church. However, the fact that they both mention that it was painted by an angel, thus attributing to it the nature of Acheiropoietos, is a strong indication that it was most probably an icon of Byzantine or Byzantinising style.

What makes these references even more interesting is the Latin inscription provided by Pierre Barbatre. An almost identical inscription appears in four 15th-century icons of the Virgin of the Passion signed by the famous Cretan painter Andreas Ritzos, as well as on the central panel of a tripartite icon of St Nicholas attributed to him. ${ }^{313}$ The iconographical theme of the Virgin of the Passion, known already from the 12th century, became popular in 15th-century Venetian Crete, mainly because of its depiction in portable icons that subsequently circulated in the West. In this type of icon the Virgin is depicted holding the Christ Child, flanked by two angels holding the instruments of the Passion, a cross, a spear and a sponge. ${ }^{314}$ Andreas Ritzos is the one credited with developing this form of the subject, appearing in the aforementioned panel around 1450, while its genesis has been suggested to have originated to meet the devotional demands of Roman Catholic patrons, a fact that justifies the Latin inscription. ${ }^{315}$ It is worth mentioning a series of iconographically similar icons without the inscription, dated to the end of the 15th century, some of them attributed to Ritzos, as well as some later ones with an inscription of similar meaning in Greek. ${ }^{316}$

312 'En la cité, vers la mer, est une aultre eglise de Jacobins moult belle et est pres de Juifz quasi parmy tous Juifz, en laquelle est une ymage de Nostre Dame en paicture et a esté paincte par ung ange; et son par escript les vers qui ensuivent: Qui primo candidissime gaudium indixit / Prehendicat nunc passionis signacula / Carnem vero chastus mortalem inductus / Timensque letum talia pavet cernendo.' Pinzuti and Tucoo-Chala 1972-1973, 123 .

313 The inscription on these icons reads: Qui primo candidissime gaudium indixit / Prehindicat nunc passionis signacula / Carmen vero XPS mortalem indutus / Timensque letum talia pavat cernedo. Newall 2016, 126-127; Cattapan 1973, 266-270.

314 On the iconography of the Virgin of the Passion, see indicatively Drandakis 1951; Sotiriou 1969; Tatić Djurić 1975; Milliner 2011.

315 Newall 2016, 128.

316 Newall 2016, 127-128, n. 136. 
The hypothesis that the Dominican monastery of Candia housed an icon of the Virgin painted by Andreas Ritzos, a local painter known for his works for Latin patrons, is quite plausible. The inscription as transcribed by Barbatre is almost identical to the one appearing in known works of Ritzos, thus allowing the supposition of the attribution of the icon to his hand. The existence of this icon of the Virgin in the conventual church of the Dominicans of Candia is mentioned only in the two travelogues. The two pilgrims referring to it, the anonymous Frenchman and the French priest Pierre Barbatre, were travelling together, along with the Italian nobleman Santo Brasca, who makes no reference to the Dominican monastery of the town whatsoever. Whether the icon was permanently kept at the church of St Peter or it happened to be housed and exhibited there for a period of time during the 148 os cannot be determined with certainty. Still, the pilgrims' references are significant, since they indicate the existence in the monastery of an Acheiropoietos, as they attest, icon, one that could be identified as a work of the renowned Cretan painter and whose presence is not mentioned in any other sources.

\subsection{The Augustinian Monastery of the Saviour}

The Augustinian monastery of Candia was the most important of the Augustinian houses of the province of the Holy Land. ${ }^{317}$ Its foundation was most probably linked to a papal bull of John XXII, and it may have been one of the first houses of the order that was founded in Greece. ${ }^{318}$ It was located in the modern 1866 Street and until the time of its demolition in 1970 was one of the best-preserved Venetian structures in Heraklion. ${ }^{319}$

The exact date of the monastery's construction has not been determined with certainty. The house appears for the first time in a will of 1332 , so its foundation can be safely placed before that date. The will's testator bequeathed 10 hyperpera to the Augustinians for building work and repairs, indicating the

317 The Augustinian monasteries of Greece fell under the jurisdiction of the province of the Holy Land. The province received its name from the monastery that the Augustinians initially owned in Palestine, which, however, was the first one to be lost to the order, and subsequently the province of the Holy Land comprised the insular monasteries of Greece and Cyprus. It was probably founded before 1317 and was sometimes referred to as the Provincia Ultramarina or the province of Cyprus. See Tsougarakis 2012, 234, nn. 1-2.

318 About the Augustinian monastery of the Saviour in Candia, see Gerola 1908, 120-121; Tsougarakis 2012, 243-247; Kitsiki-Panagopoulos 1979, 94-95; Georgopoulou 2001, 143145; Ilko 2020.

319 Georgopoulou 2001, 143-145. 
existence of the monastery. ${ }^{320}$ Archaeological and architectural evidence also points to a construction date in the late 13th century or the early 14 th. ${ }^{321}$

Numerous surviving wills that bequeathed money to the monastery attest to the fact that it was one of the most important Latin churches of the city. Further bequests enriched the monastery's landholdings, while there were also many endowments for chapels and family tombs of noblemen in the church.322 The importance of the Augustinian monastery of Candia is also highlighted by the fact that at the General Chapter of Avignon in 1368 it was decided that the monastery would be the one to house the province's studium generale. It is not known if the Augustinians possessed a library like the one the Franciscans of the town did, nor if the 1368 decision for the studium was actually realised. However, the fact that it was the Candiot monastery that was selected to house it strongly indicates that it was one of the most important and prosperous monasteries of the Augustinian province of the Holy Land. ${ }^{323}$

The conventual church of the Saviour of the Augustinians was perhaps the largest Latin church in the city of Candia. It had one nave $(44 \times 16 \mathrm{~m})$ that ended in a rectangular sanctuary. Its plan was simple and modest, and very few subsequent modifications altered its original form (Fig. 80). The choir was covered by two ribbed vaults, and the side walls were pierced by pointed arch windows and reinforced by nine buttresses on each side. The church was covered by a pointed wooden roof, and a bell tower rose on its north-west side. ${ }^{324}$ The conventual buildings were located to the south of the church.

As far as the interior of the building is concerned, no material elements have survived to attest to its form. It was, as already mentioned, a large space, lit by several windows on its side walls. Based on the wills mentioning the church, we can deduce that elaborate altars and family chapels housing the tombs of members of prominent Candiot families could be found inside it. In 1625 ten altars were located in the church, while the high altar, dedicated to St Augustine, was covered in gold and bore the arms of the Piovence family. 325 The bronze lectern of the choir, which was decorated with an angel, was transferred in 1669 to Venice, to the church of Santo Stefano, but is no longer

\footnotetext{
320 McKee 1998, vol. 2, 503-505.

321 Kitsiki-Panagopoulos 1979, 94.

322 At the end of the 16th century two dukes of Candia were buried in the church. Georgopoulou 2001, 144; Tsougarakis 2012, 243.

323 Tsougarakis 2012, 246-247.

324 The bell tower was converted into a minaret when the church was turned into a mosque following the Ottoman occupation of the island. Georgopoulou 2001, 144; Gerola 1908, 121.

325 Georgopoulou 2001, 145; Panagiotakis 1987, 106-107; Ilko 2020, 11.
} 


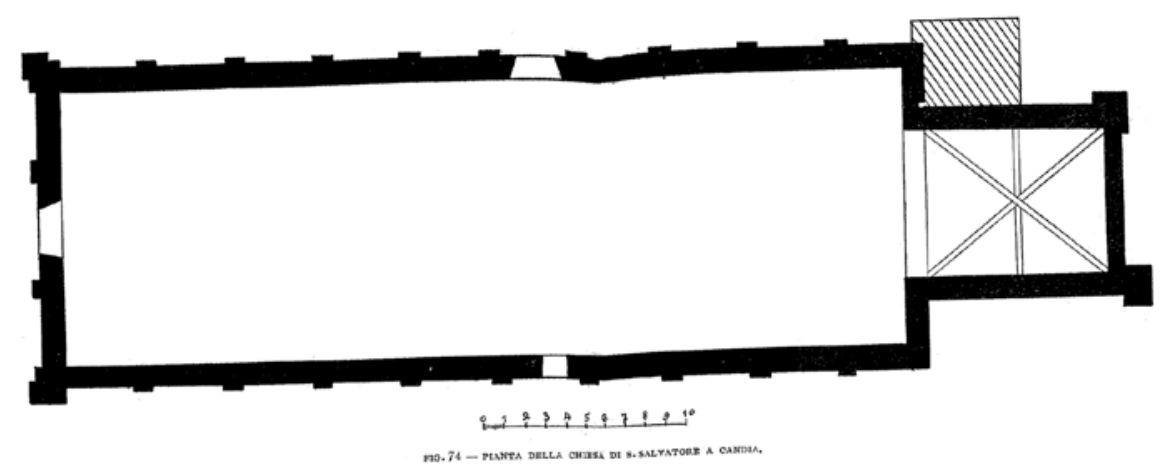

FIGURE 80 Plan of the Augustinian monastery of the Saviour, Heraklion

extant. ${ }^{326}$ A very interesting and quite detailed insight into the decoration of the Augustinian conventual church was provided by the Dominican friar Felix Fabri (1480, 1483-1484), who describes the stalls of the choir decorated with figures of Christ, the Virgin, the apostles and St Augustine, as well as of the patrons of the church, carved in cypress wood. ${ }^{327}$

As already mentioned, the Augustinian monastery of Candia seems to have been the most celebrated one of the province of the Holy Land. Its significance for the order, as well as for the city of Candia, is not at all reflected in the pilgrims' narratives. The monastery is referred to in very few travelogues, most of which restrict its existence to a simple mention.

The first pilgrim to mention the Augustinian monastery of Candia is the Florentine merchant Felice Brancacci (1422-1423), who actually visited the conventual church twice during the celebrations of the saint's feast (6 August), in which the duke participated: '[...] and they led us to a church of the Saviour, where there was the feast day, and there we heard the vespers [...] On the sixth

326 Georgopoulou 2001, 145; Gerola 19o8, 120; Ilko 2020, 15.

327 'Stalla vel sedilia chori sunt ingenioso artiftcio de lignis cypressinis facta, ita, quod supra quodlibet sedile est sculpta imago aliqua, Domini Jesu, beatae Virginis, apostolorum omnium, beati Augustini, et imagines patronorum ecclesiae.' Fabri continues by mentioning an incident of vandalism of the holy figures by a Greek 'heretic', an act that, according to the Dominican friar, was driven by the Greek's hatred towards the Latin Church: 'Sed imagines illae passae sunt injuriam, quae etiam usque in contumeliam imaginatorum pertingit; quidam enim graecus haereticus, occulte ingressus ecclesiam, abscidit nasos, omnium imaginum et opus egregium et devotum confudit. Sic enim Graeci, ubicumque possunt, nostras confundunt ecclesias, et si eis aditus ad sacra et sacramentalia patet, in odium Latinorum vel ea furantur vel effundunt.' Hassler 1843-1849, vol. 3, 282. 
day the duke invited us to hear the mass, honouring us, and so we went to the aforementioned church $[\ldots]]^{\text {?328 }}$

Just over 40 years later, in 1469 , an anonymous traveller makes mention of the monastery and its church. ${ }^{329}$ Following these references, and with the exception of the descriptive Dominican friar Felix Fabri, four other pilgrims mention the Augustinian monastery of Candia, without providing any further information about it, besides that it was a very beautiful church. The last mention of the monastery within the time frame of this study was made by the mayor of the city of Mons, Georges Lengherand (1485-1486), again in the form of a passing reference.

Over the course of its history, the monastery does not seem to have undergone large-scale reconstructions, thus its original form was preserved. ${ }^{330}$ The friars resided in it until the island's occupation by the Ottomans. Following 1669, the conventual church was converted into a mosque, the Valide Sultan Cami. After the end of the Ottoman occupation, the building was modernised and housed a public school up until 1970, when it was demolished (Fig. 81). ${ }^{331}$

There are no specific records of relics having been kept and venerated at the Augustinian monastery of the Saviour of Candia. As already mentioned, the travelogues covering the time frame of this study make no mention of such relics or effigies in the conventual church. Nevertheless, a couple of very interesting records appear in two 17th-century travelogues, concerning an icon of the Virgin originating from Rhodes and kept and venerated in the conventual church. In particular, two Swiss travellers who visited the town in 1606 mention seeing this icon.

Johannes Habermacher, a priest from Lucerne who arrived at the port of Candia on 8 August 1606, while attesting to the existence of a (Lucan) icon originating from Rhodes, which had been translated to Crete in $15^{22}$ after that island's occupation by the Ottomans, places it in the Latin cathedral of St Titus. ${ }^{332}$ It is quite possible that Habermacher confused the icon of the

328 '...] ci menorono a una chiesa di San Salvadore, dove era il giorno la festa, e quivi udimo un vespro [...] A di 6 ci mandò il Duca a convitare a udir messa; e cosi andamo nella sopradetta chiesa, facendoci molto onore.' Catellacci 1881, 162.

329 Longo 1007, 202.

33 The church of the Saviour and the conventual buildings of the Augustinian monastery of Candia were damaged in the earthquake of 1508 and were subsequently repaired. Tsougarakis 2012, 247; Gerola 1908, 120.

331 Tsougarakis 2012, 185; Georgopoulou 2001, 141; Kitsiki-Panagopoulos 1979, 87, 90; Gratziou 2008, 211-214; Ilko 2020, 4.

$33^{2}$ '[...] Da hatt man ouch vnser lieben frowen bildnuß, so S. Lucas gemalet hatt, wöllche man von Rodis dahin bracht alls dieselbig jnsul vnder deß Türgken gwallt anno $15^{22}$ kommen.' Schmid 1957b, 176-177. 


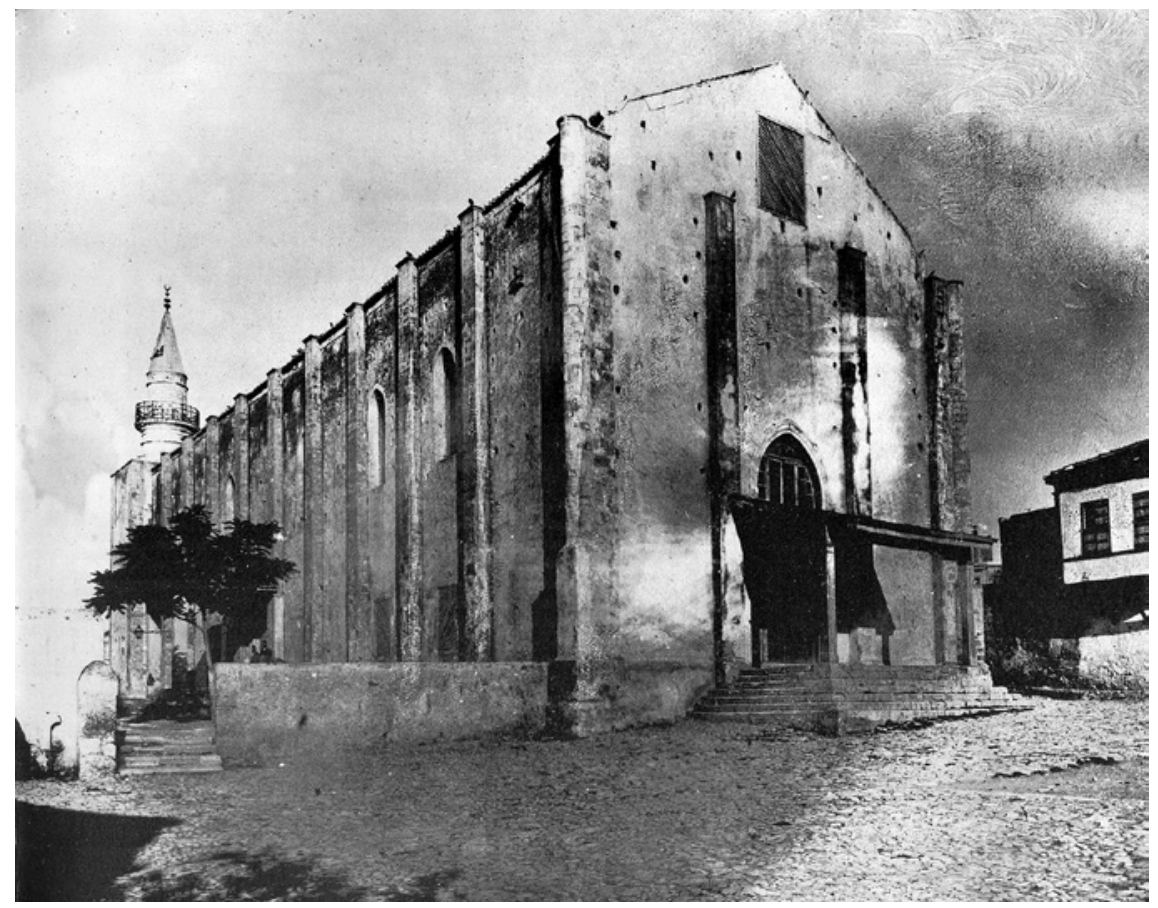

FIGURE 81 The Augustinian monastery of the Saviour, Heraklion

Mesopanditissa, which has been housed for centuries in the town's cathedral, with an icon that came from Rhodes in the mid-16th century.

The attestation of the second Swiss traveller is much more descriptive and detailed: Wolfgang Stockman refers to the Latin cathedral of the town and the icon kept in it, providing details - such as its procession to the Orthodox cathedral of the Virgin of the Angels - that make its identification with the icon of the Virgin Mesopanditissa safe, if not certain. ${ }^{333}$ Subsequently, and while describing a procession of the icon in supplication for rain, the Swiss pilgrim speaks of another icon of the Virgin, kept in the Augustinian monastery, the one also mentioned by Johannes Habermacher, originating from Rhodes and translated to Crete in $15^{22 .} .^{334}$

333 'Jtem in der sälbigen kilchen ist ein cappelen, darin ist ein altt vnser frowen bild, welches biild wunderzeigen gedan vnd noch duott. Dis gemältt bild nämend die Griechen alj ziinstdag vnd dragen es in der procesion vs gemältter kiirchen jn die kriechisch thuomkiirchen, welche la Madona di Angeli genampt. Vnd läsen alda vff griechish manier jre mäs.' Schmid 1957c, 340 .

334 ' [...] so nämend sy gemältts vnser frowen bild, nitt alein Griechen, sonder ales volch in gmein vnd dragentt es in procession wiis in das closter zuo santt Saluator, alda es ein 
The distinction between the Madonna of St Titus and the icon of the Virgin that came from the island of the Hospitallers is very clear in Habermacher's description, leaving no doubt that an icon other than the Mesopanditissa, the Lucan icon of St Francis or the one attested by the two French travellers in the Dominican monastery was kept and displayed at the conventual church of the Augustinian monastery. ${ }^{335}$

Neither of the two pilgrims referring to the icon provides any information about its form or spatial setting within the church. According to Krisztina Ilko, the icon mentioned by the Swiss pilgrims was indeed an icon of the Virgin originating from the Augustinian monastery of Rhodes, located in the chapel dedicated to the Virgin Mary. Based on its description by Archbishop Luca Stella in 1625, Ilko suggests that it was a vita icon, in which, instead of scenes from her life, scenes of miracles surrounded the central figure of the Virgin, resembling the icon of the Virgin commissioned for a Carmelite church, most probably in Nicosia. ${ }^{336}$ Whether the icon was permanently kept at the church of the Saviour or it was housed and exhibited there for a period of time that coincided with the Swiss pilgrims' visit in 1606 and that of the archbishop's in 1625 cannot be determined with certainty, since today it is lost and no other records of it have survived.

Overall, Candia presents quite a different case than the other ports of call within the area of this study. It is the town that is mentioned more than any other, appearing in over 100 travelogues. As reflected in the narratives, the town stands out as an important port of call on the way to the Holy Land. Its safe and impressively fortified harbour was a meeting point of pilgrims from all over Europe and provided amenities for traders and travellers, as well as large markets both in the town and in the borgo. These details, along with information about the island's ancient and Christian history, are recounted in every travelogue that refers to it. However, the number of pilgrims that mention one or more of its religious institutions is significantly lower. Unlike Corfu and Modon, the town of Candia pleasantly surprised the Western visitors with its large streets and beautiful buildings, the grandeur of its churches and the

ander vnser frowenbild hatt siberin, jn einem alttdar ingefasettt, welches vnser frowernbild der grosmeister von Rodis nach der vbergäbung Rodis anno $15^{22}$ mit sich in Candia mitsampt fiil anderen kilchenziertt gebracht vnd es dem closter vererett.' Schmid 1957b, 176-177.

335 Schmid 1957c, 340-341.

336 Ilko 2020, 11-12. The description of the icon can be found in Ilko 2020, 12, n. 57 . 
impressive and elaborate mendicant monasteries. In and around the town a religious traveller could visit imposing churches and monasteries and prostrate to important relics and effigies: Christological and apostolic mementoes, Lucan and miraculous Byzantine icons of the Virgin and saintly relics, as well as the mountain summit sanctified by an apostle's presence, all marking the holy topography of the town. These places and objects could not but appear in the pilgrims' narratives, inserting the island town into the topography of holy and sacred sites dotting the route to the Holy Land.

Candia is also the sole port of call in the studied area whose sacred sites do not coincide with a location evoked in the Santa Parola. In the cases of Corfu, the Strophades and Modon, each area's most eminent holy site or cult is evoked in the seafarers' prayer. Inversely, the only two sites on the island of Crete evoked in the Santa Parola are not located in the town of Candia and rarely appear in the pilgrims' narratives: the churches of the Virgin at Fraskia and Santa Veneranda in the Bay of Dermata may have been important navigational landmarks, but, as inferred by their omission from the travelogues, they were definitely not treated as worship-worthy sites by the pilgrims. ${ }^{337}$ It makes one wonder if the inclusion of two of the most prominent cults of Candia, St Titus or the Virgin Mesopanditissa, in the Santa Parola would have boosted their fame and augmented their importance in the eyes of the religious travellers.

Summing up, Candia does not appear to be treated as a place of significance in the pilgrims' itinerary in a way that corresponds to what it had to offer to a pious traveller. As in all the towns within the area of this study, it seems that the agents that could promote it and render it an eminent pilgrimage destination were not mobilised. Perhaps, following the Venetian policy of religious tolerance and keeping in mind not to threaten the fragile equilibrium between the local population and the Latins, the town's authorities, both secular and religious, decided not to market the island's sacred topography to visitors, especially since their most popular 'commodities' - St Titus's relic and the icon of the Mesopanditissa - could also be claimed by the Orthodox. Thus, the rivalry that divided the two rites prevented the formation of a common strategy to showcase the island's sacred heritage. ${ }^{338}$ In broad lines, the two major cults of Candia were strong and highly celebrated, but their promotion seems to have been mainly aimed at the locals rather than the pilgrims and travellers, and

337 In the case of Corfu the site evoked in the Santa Parola is also located far away from the town; however, it is the one amassing the largest number of references within the area of this study.

338 Georgopoulou 2013, 150-157, esp. $15^{2}$. 
it was indeed very successful on a regional level. The same appears to apply to the mendicant monasteries. The absence of references to the icon of the Virgin Mesopanditissa is perhaps the biggest puzzle when it comes to Candia, but one could postulate that the icons of the Virgin sold in the town's market, as attested by several pilgrims, were copies of the city's most venerated effigy. The holy sites of Candia have a constant presence in the travelogues throughout the 14th to the 16th centuries, but it appears that the grandeur and the richness of the relic collections of its religious institutions were not efficiently exploited, thus failing to elevate the town to the most prominent pilgrims' destination among the other ports of call within the studied area. 